\title{
Speuren op de tast: een historische kijk op industriële en universitaire research
}

Citation for published version (APA):

Homburg, E. (2003). Speuren op de tast: een historische kijk op industriële en universitaire research. Unigraphic Maastricht. https://doi.org/10.26481/spe.20031031eh

Document status and date:

Published: 31/10/2003

DOI:

10.26481/spe.20031031eh

Document Version:

Publisher's PDF, also known as Version of record

\section{Please check the document version of this publication:}

- A submitted manuscript is the version of the article upon submission and before peer-review. There can be important differences between the submitted version and the official published version of record.

People interested in the research are advised to contact the author for the final version of the publication, or visit the DOI to the publisher's website.

- The final author version and the galley proof are versions of the publication after peer review.

- The final published version features the final layout of the paper including the volume, issue and page numbers.

Link to publication

\footnotetext{
General rights rights.

- You may freely distribute the URL identifying the publication in the public portal. please follow below link for the End User Agreement:

www.umlib.nl/taverne-license

Take down policy

If you believe that this document breaches copyright please contact us at:

repository@maastrichtuniversity.nl

providing details and we will investigate your claim.
}

Copyright and moral rights for the publications made accessible in the public portal are retained by the authors and/or other copyright owners and it is a condition of accessing publications that users recognise and abide by the legal requirements associated with these

- Users may download and print one copy of any publication from the public portal for the purpose of private study or research.

- You may not further distribute the material or use it for any profit-making activity or commercial gain

If the publication is distributed under the terms of Article $25 \mathrm{fa}$ of the Dutch Copyright Act, indicated by the "Taverne" license above, 


\section{Speuren op de tast \\ Een historische kijk op industriele en universitaite research}




\section{Calofon}

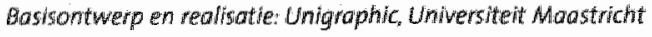

omslagillust ratie forto copyright DSM NW

ISBN $90-5681 \cdot 192-4$

NUR 680

2. Enst Hombung, Eijsden, 2003

Alte rechten woorbehouden. Niets wit deze witgave mag worden verweevoudigd, opgeshagen in aten geautomatiseerd gegevinsbestand of opentaar gemaakt, zonder woorafgaande schifte. lijke toesteming van de auteur of uitgever. 


\section{Speuren op de tast}

Een historische kijk op industrièle

en universitaire research

\section{Rede}

in verkorte vorm uitgespoken bij de aanvaarding van het ambt wan bijzonder hoogleraar Geschiedenis van Wetenschap en Techniek, en hun onderlinge samenhang, vanwege de Stichting Historie der Techniek aan de Faculteit der Cultuurwetenschappen van de Universiteit Maastricht op vrijdag 31 oktober 2003

door

\section{Ernst Homburg}




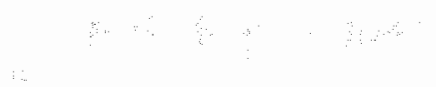

$\div$

$\therefore \quad$

$\therefore$ 


\section{Speuren op de tast}

Een historische kijk op industriële en universitaire research

Mijnheer de Rector Magnificus, Leden van het Bestuur wan de Stichting Historie der Techniek Zeer gewaardeerde toehoorders,

Binnen de Faculteit der Cultuurwetenschappen van deze universiteit belijden wij dat wetenschap en techniek een centrale rol spelen in onze moderne cultuur. Ook daarbuiten wordt het inzicht dat onze maatschappij zich ontwikkeld heeft tot een geindustrialiseerde kennismatschappij breed gedragen; althans door sommigen luid verkondigd." Kijken we terug op de afgelopen eeuw, dan kan vooral het industriêle onderzoekslaboratorium als het symbool bij uitstek gelden van dit proces van toenemende verwetenschappelijking. Het lijkt immers deze uitvindingenfabriek' te zijn geweest die in een hoog tempo als een hoorn des overvloeds, of doos van pandora, zijn zegeningen, of plagen, over de mensheid heeft uitgestort: synthetische wasmiddelen, nylon, glasvezelkabels, geneesmiddelen, Zyklon B, loodhoudende benzine, loodvrije benzine, platte beeldschermen, teveel om op te noemen. Hoewel geen van deze voorbeelden volledig op het conto van industriële laboratoria te schrijven is - innovatieprocessen zijn immers oneindig complexer em heterogenere dan technische vondsten - valt het niet te ontkennen dat in veel gevallen het werk in industriële laboratoria een belangrijke rol heeft gespeeld. In de loop van de twintigste eeuw hebben zich evenwel grote veranderingen voorgedaan in de werkwijze van deze laboratoria en in de denkbeelden die wetenschappers en ondernemers daarover hadden. Die veranderingen vormen het voornaamste onderwerp van deze rede. De universiteiten kunnen daarbij niet buiten schot blijven. Kennis- en techniekontwikkeling in industriële laboratoria heeft steeds in nauw verband gestaan met wat er aan de universiteiten gebeurde. Bowendien heeft dit thema een grote actualiteit, zoals bijvoorbeeld blijkt uit de oproep van Jo Ritzen, voorzitter van het College van Bestuur van deze universiteit, bij de opening van het academisch jaar, om een inniger band met het bedrijfsleven aan te gaan. ${ }^{2}$

Bij het voorbereiden van deze rede moest ik sterk terugdenken aan een gebeurtenis die zich ruim dertig jaar geleden afspeelde. Als jong studentlid van de subfaculteitsraad scheikunde van de Vrije Universiteit 
(Vu) hoorde ik toen een van de hoogleraren organische chemie, Wybe Nauta, die langere tijd tevens researchleider van het geneesmiddelenbedrijf Brocades was geweest, het woord nemen. Zijn collega J.G. Keppler van Unilever had telefonisch zijn beklag bij hem gedaan over het gedrag van een groep scheikunde-studenten van de VU tijdens een recente excursie naar het researchlaboratcrium van Unilever in Vlaardingen. In plaats van zich te verdiepen in de aard van het onderzoek en te informeren naar hun carrière-mogelijkheden, zoals dat sinds jaar en dag gebruikelijk was, hadden deze studenten nare vragen gesteld over zaken als de maatschappelijke wenselijkheid van de producten van het bedrijf, over de rol van Unillever in de Derde Wereld en over het gebruik wan proefdieren in het onderzoek naar cosmetica. ${ }^{3}$ De betreffende studenten waren niet meer welkom. Kon de subfaculteit geen disciplinaire maatregelen nemen en hoe kon men vergelijkbare toestanden voortaan voorkomen, vroeg Nauta zich af? Er wolgde een uitvoerige discussie die niet tot oplossingen leidde. De aanwezige hoogleraren en docenten zaten zeer met de kwestie in hun maag en maakten een wat ontredderde indruk. De VU had zich in hun ogen te schande gemaakt, maar men zag niet goed hoe zulk, onheil in de toekomst vermeden kon worden.

Wie ook enigszins ontredderd waren, achteraf gezien, waren de studenten zelf. Op de middelbare school enthousiast geworden voor de wereld van atomen en moleculen, en geintrigeerd door het vele dat er nog op quantumtheoretisch en biochemisch terrein te weten viel, waren $\mathrm{zij}$, aangemoedigd door hun ouders die meenden dat er in de chemie altijd een goede boterham te verdienen was, scheikunde gaan studeren. Eenmaal aangekomen op de universiteit vingen ze echter vele signalen op die erop wezen dat het in het wetenschappelijk onderzoek niet louter ging om intellectuele nieuwsgierigheid en zuiver wetenschappelijke vraagstukken, maa om een activiteit die achter de schermen in een belüngrijke mate door industriële doeleinden en belangen werd gestuurd."

In dit intellectuele klimaat kwam in de jaren zeventig aam de bètafaculteiten in Nederland het Wetenschap \& Samenleving-onderwijs en - onderzoek op. Nadere studie van de rol van industriële research was daarbif steevast één van de ingrediënten. Ook binnen de industriële laboratoria was er inmiddels onvrede ontstaan over de maatschappelijke implicaties wan eigen werk. Juist in een tijd waarin, zoals we nog zullen zien, de industriële onderzoekers gedwongen werden zich sterker te richten naar de signalen vanuit de markt, kwam bij henzelf de vraag 
op of hun onderzoek zich niet beter op andere prioriteiten kon richten dan op het ontwikkelen van een 'girofoon' of weer een 'nieuwe deodorant:. Bekend is het in 1973 door medewerkers van het Natuurkundig Laboratorium van Philips uitgebrachte rapport over Wetenschap en Maatschappij waarin verslagen staan van de vele discussiegroepjes die vanaf 1971 op dat zogeheten 'Nat.Lab.' actief waren geweest. ${ }^{5}$ Bij Shell vonden vergelijkbare discussies plaats.

Voor het Verbond wan Wetenschappelijke Onderzoekers, een organisatie van maatschappelijk geèngageerde wetenschappers uit de universiteiten en de industrie was dit voldoende reden om in september 1973 eerst een aflevering van het tijdschrift Wetenschap \& Samenlewing te wijden aan 'Industrieel wetenschapsbeleid' en vervolgens in mei 1974 zelfs een tweedaags congres te houden over "Industriele Research", dat het startpunt werd van een ware hausse van zogeheten 'kritische' studies en publicaties in de jaren daarna. ${ }^{6}$

Het zou te ver voeren op deze plats hiervan een volledig overzicht te geven. Ik noem enkele namen en onderzoeksrichtingen als korte aanduidingen van een veel breder veld van activiteit." Philip Vergragt, Sjerp Zeldenrust en Paul de Laat in Groningen, Loet Leydesdorff in Amsterdam en Kees Blase in Utrecht hielden zich bijvoorbeeld bezig met de demo cratisering van het industriële onderzoek en met de belangenbehartiging van de "wetenschappelijke werkers". Daarnaast analyseerden Vergragt, Pieter Weeder, Do Kester, Gerard de Vries en, later, Karel Mulder in Groningen de wijze waarop in de industrie besluiten over onderzoeksprioriteiten tot stand kwamen. Joop Schopman onderzocht vergelijkbare vraagstukken vanuit de RU Utrecht," terwijl Andries Sarlemijn, Peter Kroes en Hans Hutter dit thema in Eindhoven oppakten." Arie Rip in Leiden en Nico Wijnbeek in Amsterdam richtten zich, evenals later Loet Leydesdorff en Sjerp Zeldenrust, op wetenschapsdynamische vragen betreffende de invloed van de industrie op de ontwikkeling van onderzoeksgebiederin."

Ook het thema van deze rede, de geschiedenis van het industriele onderzoek, kwam op agenda te staan. In 1977 studeerde Erik Bloemen in Leiden af op een scriptie over Onderzoek en ontwikkeling door het bedriffsleven in Nederland, 1919-1939." Het jaar daarop entameerde Wim Hornix in Nijmegen een groot onderzoeksproject naar de industrialisering van de wetenschap' in de tweede helft van de negentiende eeuw onder invloed van de synthetisch kleurstoffenindustrie, dat halverwege 1979 van start ging:" en kort daarna startte Harry Lintsen in Eindhoven als uitvloeisel van Techniek \& Samenleving-onderwijs historisch onder- 
zoek naar technische innovaties in de margarine-, electrotechnischeautomabiel- en, eveneeris, synthetische kleurstoffenindustrie." In het buitenland wond een wergelijkbare plotselinge bloei plaats van de studie van de relaties tussen wetenschap en industrie.

Terugkijkend op die publicaties uit de jaren zeventig en vroege jaren tachtig constateer $i k$ dat er in de meeste gevallen sprake was van een gepolariseerd wereldbeeld, zowell in politieke als in cognitieve zin. in politieke zin, omdat kritiek op de grote multinationale industrie in veel gevallen de motivatie vormde om zich op dit terrein te gaan begeven. Deze politieke polarisatie verdween in de loop van de jaren tachtig grotendeels. Enerzijds, omdat veel van de betrokken onderzoekers hun eerdere categorische afwijzing van de voortbrengselen van het groot-kapitaall verruilden voor een meer pragmatische houding waarin zij kwesties van geval tot geval wensten te beoordelen. Anderzijds, omdat ook de industrie zelf zich communicatiever en minder polariserend ging opstellen. De kritiek werd niet alleen aangehoord, maar leidde ook daadwerkelijk tot veranderingen. Hierdoor was het mogelijk dat in 1988 door het Koninklijke Instituut van Ingenieurs (KIVI), op initiatief van de uit Wetenschap \& Samenleving voortgekomen Eindhovense onderzoeksgroep onder leiding van Lintsen, de Stichting Historie der Techniek kon worden opgericht, de stichting die de leerstoel instelde wairop degene waar u inu naar luistert is benoemd."

Wat betreft de polarisatie in cognitieve zin, die vooral draaide om de wijze waarop begrippenparen als weterischap en techniek en wetenschap en industrie werden gebruikt, is het goed de toen populaire 'Bernalvorken' van de Wageningse Wetenschap \& Samenleving-medewerker Chris Boers in herinnering te roepen. Dit waren op weesworken gelijkende schema's, geïnspireerd door het werk van de Britse kristallograaf, wetenschapshistoricus en socialist John Desmond Bernal, die erop neer kwamen dat wetenschap en ind ustrie zeer lang gescheiden wegen hadden bewandeld, totdat ze op een zeker moment in de geschiedenis in innig contact met ellkaar waren gekomen en sindsdien als één geheel - geindustrialiseerde wetenschap, annex science-based-industry - verder waren gegaan."

Deze tamelijk romantische kijk op de geschiedenis van de wetenschap, waarin de idylle van een eeuwenoude, zuivere wetenschap werd gekoesterd, was een denkstijl die reeds lang bestond. Marx" omkering van Hegel indachtig, hebben de kritici van de jaren zeventig de daarmee verbonden metaforen 'auf' die Füsse gestellt', zonder evenwel het daar- 
onder liggende polaire denkpatroon aan te tasten. Ging het oorspronkelijk om het beeld van een huwelijk tussen wetenschap en industrie, of om een Sneeuwwitje-achtige situatie waarin de wetenschap de ingedutte, behoudzuchtige industrie had wakker gekust, nu was er - ook in het buitenland - sprake van een 'zondeval' van de wetenschap die in de greep van het kapitaal, of, nog erger, van het militair-industrieel-complex was geraakt. Titels als Armin Hermanns, Wie die Wissenschaft ihwe Unschuld verlor en Jonathan Slacks, 'Class struggle among the molecules" mogen hier als korte aanduiding dienen voor toen ruim verbreide gedachten. ${ }^{18}$

Over het tijdstip van deze 'zondeval" was minder eenstemmigheid. Sommige leden van de studentenbeweging meenden ongetwijfeld dat dit welhaast apocalyptische gebeuren zich in hun eigen studententijd aan het voltrekken was. Was de universiteit immers nilet altijd een duffe, iworen toren geweest, die pas sinds kort door het grootkapitaal werd belaagd? Anderen meenden dat de oorsprong in de jaren vijftig lag toen - tegen de achtergrond van de Koude Oorlog - de zogeheten Tweede Industriële Revolutie, of Wetenschappelijk-Technische Revolutie momemtum kreeg. ${ }^{19}$ Weer anderen echter, concludeerden in navolging van Bermal dat de beslissende zondeval van de wetenschap zich veel eerder had voorgedaan, namelijk in het laatste kwart van de negentiende eeuw, toen de kleurstofindustrie en de electrotechnische industrie wetenschap op grote schaal voor hun eigen doeleinden gingen inschakelen.

Tussen beide laatste thesen bestaat - het adagium 'all history is contemporary history indachtig - een nauw verband. Bernals boek en de eerste grondige historische studies over de ontwikkeling van het industriele researchlaboratorium, geschreven door de Amerikanen Kendall Birr en John Beer verschenen in de jaren vijftig, en werden sterk beinvloed door de publieke en politieke issues van hun tijd. ${ }^{\text {io }}$ Toen een nieuwe generatie onderzoekers in de jaren zeventig en tachtig opnieuw de geschiedenis van de industriele wetenschap ter hand nam importeerde" deze (aanvankelijk) als het ware de denkpatronen die in die studies uit de jaren vijftig waren vervat. Die denkpatronen wortelden op hun beurt weer voor een deel in de retorische repertoires wan de naar macht en aanzien strevende professionele wetenschappers uit de tweede helft van de negentiende eeuw. Dat het beeld van de ivoren toren en het idee van een langdurig gescheiden optrekken van wetenschap en industrie zich zo hardnekkig hebben kunnen handhaven komt mijns inziens doordat Bernal, Boers en de auteurs op wie zij zich baseerden de retoriek van de wetenschappers niet kritisch tegen het licht hebben 
gehouden. In plaats van de praktijk wan de wetenschap te onderzoeken, hebben ze zich op uitspraken over die praktijk gebaseerd, daarbij niet onderkennend dat het geschetste polaire beeld een onderdeel was van de professionaliseringsstrategle van de door hen bestudeerde wetenschapsmensen. ${ }^{2 s}$

Bij deze typering van enig gedachtengoed uit de jaren zeventig will ik het laten. Drie zaken heb ik willen benadirukken. In de eerste plaats de explosief groeiende aandacht voor de ontwikkeling van industriële research in de jaren zeventig en tachtig. Ten tweede het sterk politiek geinspireerde, dualistische gebruik wan de begrippen wetenschap en industrie. En tenslotte de these dat deze dualistische omgang met die begrippen stamde uit een geheel andere politieke context, namelijk die van de inschakeling van de wetenschap in de Koude Oorlog, terwijl ze indirect terugging op retorische repertoires ower de verhouding tussen wetenschap en industrie die door negentiende-eeuwse wetenschappers waren ontwikkeld.

Denkbeelden over de historische verhouding tussen wetenschap en industrie hebben zich inmiddels radicaal gewijzigd. Het geschetste polaire beeld is feitelijk onjuist gebleken en de herkomst ervan blijkt goeddeels terug te voeren op een nalef gebruik van bronnen. In de angeveer vierhonderd jaar dat de scheikunde inmiddels als universitaire discipline bestaat is er geen periode aan te wijzen waarin dit vak niet in contact stond met de ambachtelijke of industriële praktijk. De veronderstelde vredige idylle van het zuiver-wetenschappelijke, onbekommerde vorsen heeft - sommige individuen daargelaten - voor het vak als geheel nooit bestaan. Voor andere vakken ligt dit ongetwijfeld genuanceerder, maar als kanttekening bij door velen gekoesterde opvattingen over de industrialisering van de wetenschap in de late-negentiende eeuw, of over de universiteit als ivoren toren, is dit voorlopig voldoende. $U$ zult nog verschillende voorbeelden de revue zien passeren die aangeven hoe innig de verhouding tussen universiteit en industrie soms was.

In het vervolg van dit verhaal wil ik voor Nederland in de twintigste eeuw een beeld neerzetten van de mijns inziens meest belangrijke ontwikkelingen in de verhouding tussen wetenschap en industrie. $1 \mathrm{k}$ concentreer me op het industriële researchlaboratorium en de daarmee direct verbonden universitaire wetenschap. Drie zaken stel ik daarbij aan de orde: 
In de eerste plaats de periodisering: welke fasen zijn er te onderkennen. Wat typeert hen, en waarom traden er, soms radicale, koerswijzigingen op?

In de tweede plaats: welke verbindingslijnen liepen er tussen die industriele researchlaboratoria onderling en tussen hen en de verschillende instel lingen voor hoger onderwijs en onderzoek? Er is in de laatste 15 à 20 jaar veel literatuur verschenen over zogeheten Nationale Innovatiesystemen. Daarbij ging veel aandacht uit naar de invloed op innovatieprocessen van nationale instituties als de octrooiwetgeving. het belastingregime en dergelijke, en naar de relaties tussen bedrijven, universiteiten en grote onderzoeksinstellingen als TNO, ECN. Wat echter niet of nauwelijks de aandacht kreeg zijn de verbindingslijnen tussen de grote bedrijven onderling. Het is mijn stellige overtuiging dat de relatief sterke positie van Nederland op het gebied van wetenschap en techniek in belangrijke mate wordt bepaald door de aanwezigheid van de researchinstelingen van een vijftal grote multinationale bedrijven, de zogeheten 'Grote Vijf' - Philips, Shell, Akzo, Unilever en DSM. Niet alleen omdat ze gedurende decennia op zich reeds zo'n 65 procent van alle particulier gefinancierde research voor hun rekening namen, maar juist door de onderlinge wisselwerking tussen de kenniscentra van die bedrijven. ${ }^{23} \mathrm{k} z$ al verschillende voorbeelden geven hoe deze bedrijven van elkaars aanwezigheid hebben geprofiteerd.

In de derde plaats zal ik het ongrijpbare, soms haast modieuze karakter van de opgetreden koerswijzigingen benadrukken. Het is op dit punt dat er van het 'Speuren op de tast' uit de titel van deze rede sprake is. U dacht ongetwijfeld dat dit over het onderzoeksproces zelf zou gaan. Daar zit zeker als het zich op nieuwe gebieden waagt inderdaad ook een element van 'speuren op de tast' in. Maar daarop ligt mijn focus niet. Een tweede mogelijk is, dat deze oratie zelf een 'speuren op de tast" maar de geschiedenis van de Nederlandse industriële research behelst. Dat is zeker het geval. Er is nog zo weinig diepgaand onderzoek gedaan, er liggen nog zoveel vragen open, dat ik inderdaad het gevoel heb dat ik $u$ over de toppen van enkele ijsbergen ga voeren, waarbij zich het meeste nog onder het wateroppervlak bevindt en ook voor mijzelf verborgen is. Toch was ook dit het niet dat voor ogen had toen ik voor deze titel koos.

Behalve de geschiedenis van het speuren, het onderzoeken zelf, is er nog een andere geschiedenis te vertellen, namelijk die van het denken over hoe je dat speurwerk moet gaan inrichten. Hoe moet je een labora- 
torium runnen? In hoeverre mogen onderzoekers zich op fundamentele, wetenschappelijk vragen richten? Mogen zij publiceren, of moeten zij zaken juist geheimhouden? Hoe intensief dient er met de universiteiten te worden samengewerkt? Op deze en andere vragen zijn in de loop van de tijd heel verschillende antwoorden gegeven, zoals ik zal laten zien. verschillen van inzicht over deze zaken duren voort tot de dag van vandaag. Er gaan miljarden Euro's om in het industriële onderzoek in Nederland, vele beslissingen zijn aan strakke, rationele procedures gebonden, maar fundamentele strategische keuzes bevatten ook een arbitrair element. in die zin speuren en speurden ook grote multinationale bedrijven voor een belangrijk deel op de tast.

Ik heb de ontwikkeling van de industriële research in Nederland in vier fasen verdeeld, die ik hierna zal langslopen. Zij vormen de structuur voor de rest van dit verhaal.

1 De eerste fase is de fase van de opkomst van de industriele research in Nederland in de eerste vier decennia van de twintigste eeuw.

2 De daarop volgende fase heb ik de fase van de fundamentele research genoemd, omdat ze gekenmerkt wordt door het grote belang dat bedrijven in die tijd hechtten aan het doen van diepgravend wetenschappelijk onderzoek. De fase overlapt deels met de eerste, want in sommige bedrijven startte fundamenteel gericht onderzoek reeds ruim voor de Tweede Wereldoorlog.

3 De derde fase, die gekenmerkt wordt door een groeiendle oriëntatie op de markt, begon omstreeks 1965. Terwijl er gedurende de twee eerste perioden sprake was van een gigantische groei van het industriële onderzoek in Nederland, zowel in de breedte, wat betreft het aantal betrokken laboratoria, als wat betreft de omvang van die afzonderlijke labs, trad er aan het eind van de jaren zestig stagnatie in Veel laboratoria bereikten toen hun grootste omvang ooit. Daarna zijn ze ofwell op hetzelfde peil gebleven, of gekrompen.

4 In de jaren tachtig van de twintigste eeuw kwam het industriële ondlerzoek geleidelijk in een nieuwe, vierde fase terecht. In de situatie van stagnatie veranderde op zich niet veel: kortstondige perioden van groei en krimp wisselden zich in veel gevallen af. Ook de keuze voor een sterke marktorientatie bleef. Reden om toch van een nieuwe fase 
te spreken vormt het groeiende belang dat aan kennisnetwerken en aan samenwerking met universiteilten werd toegekend. Aanvankelijk ging het daarbij vooral om nationale contacten en netwerken, maar in de loop van de jaren negentig werden mondiale netwerken steeds belangrijker.

De eerste twee fasen behandel ik het uitvoerigst, de laatste twee stip ik slechts aan. Zij moeten nog veel beter worden onderzocht: onderzoek dat ik de komen jaren hoop te gaan doen. Ze zouden een mooi thema kunnen vormen voor een afscheidsrede.

Maar ik loop te ver vooruit op toekomstige zaken. Laten we eerst terug gaan naar het begin van de twintigste eeuw.

\section{De eerste industriële laboratoria}

In 1927 promoveerde de Duitser Heinz Woltereck in Leipzig op een proefschrift over de ontwikkeling van de Nederlandse chemische industrie tussen 1914 en 1925. Dat boek bevat, gekleurd door een Duitse bril, een aantal interessante constateringen over de verhoudingen tussen wetenschap en industrie. Vergeleken met Duitsland waren deze verbindingen er - volgens Woltereck - nauwelijks en zelfs in 1926 bestonden er nog vrijwel geen industriële researchlaboratoria. Wetenschappers keken in Nederland vaak meer op de industrie, zodat de industriële arbeidsmarkt in feite voor tweederangsfiguren was. Sinds de Eerste Wereldoorlog was men, naar Duits voorbeeld, wetenschappelijker gaan werken. Maar deze vernieuwing beperkte zich, zo stelde hij, vooralsnog tot de universiteiten. ${ }^{24}$

Hoewel niet op alle onderdelen juist, zijn Wolterecks beweringen wat de hoofdlijn betreft zo gek nog niet. Terwijl in de negentiende eeuw Duitse universiteiten honderden chemici afleverden die in de industrie gingen werken, kwam dat toen in Nederland nog vrijwel niet voor. De natuurwetenschappelijke faculteiten aan de universiteiten waren er voor het opleiden van universitaire wetenschappers en leraren. Voor de technische ambtenaren en, in mindere mate, woor de industrie was er een aparte school, die duidelijk een trapje lager gedacht was: de Polytechnische School in Delft, die in 1905 tot Technische Hogeschool verheven zou worden. In de twintigste eeuw zou deze duale opleidingsstructuur veranderen, maar dat gebeurde slechts langzaam. ${ }^{25}$ Het verschil met Duitsland was opvallend. Dat gold ook voor de industriële laboratoria. Toen Philips en de Bataafsche Petroleum Maatschappij (BPM), de Nederlandse werkmaatschappij van de Koninklijker Shell, 
omstreeks 1910 de eerste industriële onderzoekslaboratoria oprichtten, bestonden zulke inrichtingen in Duitland reeds enkele decennia. In dat land was in de jaren zeventig en tachtig van de negentiende eeuw het fenomeen "industrieel researchlaboratorium" voor het eerst ontstaan toen Duitse synthetische kleurstoffabrieken aparte afdelingen gingen oprichten voor het doen van onderzoek.

Eén mogelijk misverstand wil ik hier bijvoorbaat wegnemen: dit waren zeker niet de eerste laboratoria in de industrie. In 16 de en 17 de eeuwse bronnen over de chemische nijverheid is reeds sprake van "laboratoria". Dat waren aanvankelijk chemische "werkplaatsen" waar chemische en farmaceutische producten werden gemaakt, kortom in feite de fabrieken zelf." Vanaf het midder van de 18 de eeuw dook vervolgens een nieuw type laboratorium op: een van de fabriek afgescheiden ruimte, waarin proeven konden worden gedaan. Deze proeven betroffen aanvankelijk vooral de analytisch-chemische controle van grondstoffen, producten en het fabricageproces. Deze laboratoria, die in de 19 de eeuw in geen enkele chemische fabriek van enige omvang ontbraken stonden dus geheel ten dienste van het eigenlijke productieproces. Dat was hun hoofdtaak. Soms echter deden chemisch-geschoolde ondernemers of bedrijfsleiders ook verdergaande proeven in deze laboratoria, bijvoorbeeld gericht op het onderzoeken van knelpunten in de productie, of op het verbeteren van een product, of - in enkele gevallen - op het vinden van nieuwe producten. ${ }^{28}$

Eerst tegen deze achtergrond kan de oprichting van industriële researchlaboratoria door kleurstofproducenten als BASF, Hoechst, Oehler, Agfa en Bayer in het juiste perspectief worden geplaatst. Het waren niet de eerste industriële laboratoria waar chemisch onderzoek plaatsvond, en evenmin de eerste laboratoria waar industriële uitvindingen en innovaties uit voortkwamen; maar wèl de eerste laboratoria die, functionerend naast de bestaande fabriekslaboratoria, wetenschappelijk onderzoek en het winden van nieuwe producten tot hoofdtoak hadden. Waarom deze laboratoria op dat moment binnen de Duitse kleurstofindustrie ontstonden heeft te maken met een aantal zeer specifieke omstandigheden, waarbij felle oligopolistische concurrentieverhoudingen, octrooiwetgeving, en recente ontwikkelingen in de organische chemie een rol speelden. Toen de voordelen die deze nieuwe organisatieworm de pionierende bedrijven BASF en Hoechst opleverde omstreeks 1880 steeds duidelijker aan het licht trad, konden de overige Duitse kleurstofbedrijven, onder het regime van de in 1877 totstandgekomen Reichspatentgesetz, niet achterblijven. Tussen 1882 en 1886 volgden alle 
grote Duitse kleurstofproducenten het voorbeeld van de twee pioniers.

In prachtige studies hebben Georg Meyer-Thurow en Carsten Reinhardt het ontstaan en de verdere groei van deze kleurstofresearchlaboratoria laten zien. Bij BASF en Bayer ontstond de nieuwe organisatievorm min of meer van onderop, rond bedrijfschemici als Heinrich Caro en Carl Duisberg, terwijl bij Hoechst en Agfa het topmanagement het initiatief nam, onder meer door privaat-docenten en hoogleraren van de universiteiten te recruteren en die aan het hoofd van de nieuwe laboratoria te zetten. In de loop van de jaren tachtig en negentig groeiden deze laboratoria tot betrekkelijk grote organisaties uit met verschillende ondersteunende diensten, zoals een octrooibureau, een bibliotheek, een analytisch controlelaboratorium, een proefververij, een semi-technische afdeling en een opleidingslaboratorium. Deze laatste voorziening wijst erop dat het researchlaboratorium op den duur ook een socialisatiefunctie kreeg. Voordat ze in de fabriek werden losgela. ten', brachten chemici eerst enkele maanden in het laboratorium door om daar kennis te maken met de bedrijfscultuur en met de belangrijkste producten en technieken. $\| n 1900$ werkten er 134 chemici bij Bayer: ongeveer 110 in de fabrieken en fabriekslaboratoria en ruim 20 in het centrale researchlaboratorium. Daar de staf van zo"n laboratorium doorgaans voor ongeveer 20 procent uit academici bestond mogen we aannemen dat er toen ongeveer 100 personen bij Bayer in de research werkzaam waren. Deze liedern synthetiseerden en onderzochten ongeveer 2500 nieuwe kleurstoffen per jaar, waarvan er zo'n 30 de markt haalden. Daarnaast was de ontwikkeling van synthetische geneesmiddelen inmiddels opgepakt. De BASF-fabrieken in Ludwigshafen beschikten tezelfdertijd over maar liefst achttien laboratoria: veertien fabriekstaboratoria en vier researchlaboratoria. Naast het in de jaren zeventig opgerichte Hauptlaboratorium had men toen ook binnen drie productieafdelingen aparte researchlaboratoria opgericht. ${ }^{\text {a }}$

Deze ontwikkelingen in Duitsland bleven in het buitenland niet onopgemerkt. Op kleinere schaal richtten ook. Franse, Zwitserse en Britse kleurstoffabrieken researchlaboratoria op en omstreeks 1900 ontstonden ook de eerste onderzoekslaboratoria in de Duitse en Amerikaanse electrotechnische industrie. Vooral de naar Duits voorbeeld vormgegeven laboratoria van de Amerikaanse bedrijven General Electric en AT\& T, wier chemici en fysici vaak in Duitsland hadden gestudeerd, kregen weldra een grote omvang en reputatie. Redenen om zulke laboratoria op te richten waren, naast reeds genoemde zaken als de felheid van de concu rrentieverhoudingen en de grote rol van octrooien, dit- 
maal yooral nieuwe technische ontwikkelingen die steunden op fysischchemische en fysische expertise die deze bedrijuen niet in huis hadden en die hun kerntechnologieën dreigden te ondermijnen. "Door onderzoekslaboratoria op te richten en die te bemannen met experts op die nieuwe gebieden moest getracht worden het gevaar te keren.ook bedrijven als Du Pont, Kodak en Standard Oil gingen aan het begin van de twintigste eeuw over tat de oprichting van aparte researchlaboratoria. ${ }^{3 x}$

Omstreeks dezelfde tijd werden door de BPM en Philips ook in Nederland de eerste industriêle onderzoekslaboratoria opgericht. in de literatuur over dit onderwerp wordt de primeur vaak gegund aan het in 1884 opgerichte microbiologische laboratorium van de Nederlandsche Gist en Spiritusfabriek in Delft, waar de later beroemd geworden microbioloog M.W. Beijerinck gedurende ruimı jaar werkzaam was. Men moet deze pioniersrol echter niet overdrijven. Ook bij andere Nederlaindse bedrijwen waren in de igde eeuw academici werkzaam die proeven deden die boven het routinematige uitstaken. In die zin was de situatie bij de Delftse gistfabriek helemaal niet zo bijzonder. Het is, vermoed ik, vooral Beijerincks grote reputatie geweest die de indruk heeft doen postvatten dat er bij de Gist- en Spiritusfabriek iets heel bijzonders aan de hand was. Toen Beijerinck vertrok werd hij weliswaar weer door een academicus opgevolgd, maar tot in de jaren twinig stelde zowel de omvang van het laboratorium als de aard van de daar verrichte research niet zoveel voor. Meestal sloten de thema's die werden bewerkt zeer nauw aan bif productieproblemen, zodat we eerder van trouble shooting" kunnen spreken, zoals dat in vrijwel alle fabriekslaboratoria voorkwam. In 1925 werkten er in het laboratorium van het Delftse bedrijféén academicus en 30 technici, laboranten en spoeljongens. Kort daarna werd het laboratorium aanzienlijk uitgebreid en werd er onder leiding van François Waller jir, de zoon van de directeur, een krachtig diversificatleprogramma ingezet. Pas omstreeks 1929 was er bij Gist sprake van een echte researchorganisatie (vgl, tabel $v)^{3.3}$

In het geval van de BPM en Philips kwamen voor de Eerste Wereldoorlog wèl bestendige researchlaboratoria tot stand. Beide initiatieven vormen een aardig contrast. In het geval van de BPM woltrok zich de oprichting van het researchlaboratorium min of meer bij toeval en 'van onderop'. Concuprentie door Standard Oil vormde de prikkel om de technóloog Willem Knoops, een assistent van de Delftse hoogleraar Bas Hoogewerff, in te huren om op de TH Delft experimenten te doen om de 
productkwaliteit van één van de belangrijkste producten wan de Koninklijke/Shell, Bormeo olie, te verbeteren. Toen Knoops belangrijke resultaten behaalde en de leiding van het oliebedriff hem in dienst wilde nemen, eiste en kreeg hij in 1906 een privé-laboratorium in Schiedam. Tussen 1906 en 1909 verbeterde hij daar , bijgestaan door een groeiende groep assistenten, het door hem bedachte proces. De cruciale beslissing viel in 1909 toen Knoops naar Duitsland vertrok om leiding te geven aan de bouw van de fabriek waar zijn proces in praktijk zou worden gebracht. Op grond van de gunstige opgedane ervaringen besloot de leiding van de BPM toen niet om het laboratorium te sluiten, wat meer woor de hand had gelegen, maar om het te verplaatsen naar de benzimeraffinaderij in Rotterdam en het daar voort te zetten onder een nieuwe leiding. In 1914 verplaatste men het laboratorium voor een tweede maal, nu naar Amsterdam-Noord, waar het zich tot op de dag van vandaag bevindt. Nergens in het Shell-archief heb ik aanwijzingen gevonden dat buitenlandse voorbeelden eventueel als inspiratiebron of 'model' hebben gediend woor de oprichting en verdere ontplooing van de researchorganisatie. Tot 1927 lijkt de groei van de research bij de BPM zich betrekkelijk geleidelijk en van binnenuit woltrokken te hebben. Als je al een oprichtingsjaar zou willen hangen aan dit geleidelijke proces, zou mijn woorstel 1909 zijn, het jaar waarop de directie bestoot het laboratorium van Knoops te continueren. ${ }^{34}$

Bij Philips was de oprichting van onderzoekslaboratoria veel meer een proces dat door technisch-directeur Gerard Philips 'van bovenaf' werd geinitieerd. De reden om die stap te zetten kwam overeen met de overweging die bij General Electric de doorslaggevende rol had gespeeld: de kerntechnologie van het bedrijf, de productie van gloellampen met koolstoffilament, werd bedreigd door de Duitse uitvinding van de metaaldraadlamp, waarbij de gloeidraad van metalen als wolfraam en osmium werd gemaakt. Philips had van zulke metalen en hun verwerking geen verstand en moest daarom expertise van buiten inhuren. In 1908 werd de eerste chemisch-technoloog aangesteld en omistreeks 1910 , toen de staf inmiddels was uitgebreid, was er sprake van een apart Chemisch Laboratorium. Hiler werd door de fysisch-chemicus Lodewijk Hamburger betrekkelijk fundamenteel onderzoek verricht naar de processen die zich afspelen in de gloeilamp. In 1914 zette het bedrijfeen wolgende stap door naast het Chemisch Laboratorium ook een Natuur. kundig Laboratorium op te richten onder leiding van de natuurkundige Gilles Holst, die in Leiden was gepromoveerd. Deze ontpopte zich in de jaren daarop tot een inspirerende organisator die het Nat.Lab. wist uit te 
bouwen tot het meest vooraanstaande Nederlandse industriele laboratorium uit de eerste helft van de twintigste eeuw. Recent hebben Marc de Vries en Kees Boersma twee boeken gepubliceerd, waarin fraai is beschreven hoe Holst door het organiseren wan colloquia waar topwetenschappers optraden en door een zeer liberaal publicatiebeleid de academische atmosfeer wist te creeëren die het hem mogelijk maakte eersterangs chemici en fysici over te halen bij het Nat.Lab. te komen werken. Het succesvolle laboratorium van de directe concurrent General Electric werd daarbij niet als een 'model' nagevolgd, maar vormde wel een inspiratiebron. Tegelijkertijd lukte het Holst, meegroeiend met het bedrijf, am uitstekende contacten met de directie en met de productiebedrijuen te onderhouden. is

Ik heb wat langer stilgestaan bij de oprichting van de laboratoria van de BPM (lees Shell) en Philips, omdat deze in het vervolg van het verhaal een grote rol zullen spelen. Daarnaast laat het contrast tussen beide fraal zien dat heel verschillende overwegingen invloed hadden op die oprichting, terwijl er soms wël en soms niet naar buitenlandse voorbeelden werd gekeken. Na 1910 volgden andere bedrijven snel. Dit kwam niet doordat de laboratoria van Phillps en de BPM zelf reeds tot inspirerende voorbeelden waren uitgegroeid, maar door een pistoolschot in het verre Sarajewo. De Eerste Wereldoorlog brak uit en zette de verhoudingen binnen het Nederlandse bedrijfsleven geheel op zijn kop. Bedrijven werden afgesneden van hun grondstoffen, of van hun markten. Verschillende ondernemingen, die tot dan toe hun incidentele onderzoeksvragen hadden uitbesteed aan éen van de ruilm twintig kleine particuliere laboratoria die tussen 1880 en 1910 speciaal woor dat doel in Nederland waren ontstaan, beslaten zich op nieuwe terreinem te wagen en richtten eigen onderzoekslaboratoria op om die stap voor te bereiden. ${ }^{36}$ Voorbeelden zijn de Chemische Fabriek "Naarden', de Fabriek van Chemische Producten 'Vondelingenplaat', Stikstofbindingsindustrie 'Nederland' uit Dordrecht, mede opgericht door de van Philips afkomstige chemicus Hamburger, de kabelfabriek DRAKA en de Amsterdamsche Superfosfaatfabriek (ASF). "Ook kwam het woor dat internationaal opererende bedrijven, zoals thet in de margarine-industrie werkzame Jurgens-concern en de Industriële Maatschappij Noury \& Van der Lande, die meel- en olie-fabrieken bezat, aanleiding zagen om hun technici deels uit Duitsland naar Nederland over te plaatsen en daar laboratoria op te richten die zich bezig hielden met de nieuwe technologie van de vetharding en met andere technieken tot productverbetering. V/ak na 
de oorlog volgde nog de oprichting van laboratoria door Jurgens' concurrent en jarenlange aartsvijand Van den Bergh en door thet Arhemse kunstzijdebedrijf Enka, terwijl Staatsmijnen bij haar cokesfabriek een bescheiden fabriekslaboratorium inrichtte, dat evenwel voorlopig geen duidelijke researchtaken had..$^{38}$

De schets van deze oprichtingshausse (tabel 1 ) en het succesverhaal over Holst zouden de indruk kunnen wekken dat de oprichting van een researchorganisatie een fluitje van een cent was. ${ }^{39}$ Dat zou een ernstige misvatting zijn. In het geval bijvoorbeeld van het Jurgens-concern - één van de voorlopers van Unilever - was het een moeizaam proces. Jurgens richtte in 1916 een onderzoekslaboratorium in bij zijn oliefabriek in Zwijndrecht. Hij wist de Delftse hoogleraar organische chemie Jacob Böeseken als adviseur aan zijn bedrijf te verbinden en nam verschillende technologen en chemici in dienst. Een duidelijke managementstructuur voor de aansturing van de research ontbrak echter. De betreffende chemici, die toch ook onderzoek deden dat voor andere fabrieken van Jurgens van belang was, vielen hierarchisch onder de locatiedirecteur van de fabriek in Zwijndrecht. Ook toen twee jaar later de Delftse hoogleraar chemische technologie Alphons Steger bij Jurgens tot Wetenschappelijk Adviseur van de directie werd benoemd, veranderde deze situatie niet. Het dossier-Steger in het Unillever-archief in Rotterdam roept het beeld op van één grote lijdensweg. Steger probeerde gedurende enkele jaren de vethardingsresearch in Zwijndrecht aan te sturen, maar kreeg geen poot aan de grond bij de lokale bedrijfsleiding. Toen Anton Jurgens na herhaald verzoek de bevoegdheden van 5 teger niet verruimde, verloor deze zijn interesse en stortte zich in de politiek. In 1925 verliet hij het Jurgens-concern definitief. Het duurde tot halverwege de jaren dertig eer het onderzoekslaboratorium in Zwijndrecht zich werkelijk begon te manifesteren. ${ }^{\circ}{ }^{\circ}$

Ook in andere gevallen ging het mis. Verschillende onderzoekslaboratoria, zoals dat van de Amsterdamsche Superfosfaatfabriek en "Vondelingenplaat", werden na de oorlog sterk ingekrompen of zelfs gesloten, omdat de omstandigheden die tijdens de oorlog de oprichting hadden bevorderd waren veranderd. We moeten ons dan ook geen overdreven voorstellingen maken van het Nederlandse industriêle researchlandschap aan het begin van de jaren twintig. Op het BPM-laboratorium in Amsterdam werkten toen zo'n 40 mensen, op het Nat. Lab. van Philips slechts ongeveer de helft. Alle andere onderzoekslaboratoria waren ver moedelijk nog kleiner. Vergelijken we dit met de situatie van de Duitse 
Tabel De eerste Nederlandse industriele researchlaboratoria lde fortallen twssen

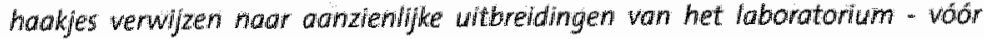
1940).

\begin{tabular}{|c|c|c|c|}
\hline Oprichting & $\begin{array}{l}\text { (Technologische) } \\
\text { uitdaging }\end{array}$ & Laboratorium & $\begin{array}{l}\text { Academische } \\
\text { adviseur(s) }\end{array}$ \\
\hline $\lg 09(\lg 27)$ & $\begin{array}{l}\text { kwalitet Borreo oller } \\
\text { concurrentie }\end{array}$ & $\begin{array}{l}\text { Lab BPM, Rottiendam, } \\
\text { 1944 Aimsterdarn } \\
\text { (later: KSLA) }\end{array}$ & $\begin{array}{l}\text { Watermam (THO): } \\
\text { Schetfer (THD): } \\
\text { Wibaut (CU) }\end{array}$ \\
\hline 1910 & $\begin{array}{l}\text { metaaldraadlamp } \\
\text { (nieuwe technologie) }\end{array}$ & $\begin{array}{l}\text { Chemisch } \\
\text { Laboratorium Philips }\end{array}$ & Reinders? (THD) \\
\hline $914(1923)$ & $\begin{array}{l}\text { halfwettlamp met } \\
\text { inest gas }\end{array}$ & $\begin{array}{l}\text { Matuurkundig } \\
\text { Laboratorium Phillps }\end{array}$ & $\begin{array}{l}\text { Ehrenfest (RUL) } \\
\text { Ornstein (RUU) }\end{array}$ \\
\hline 1914 & $\begin{array}{l}\text { product differentiatie } \\
\text { allw WoI }\end{array}$ & $\begin{array}{l}\text { Chemische Fabriek } \\
\text { "Naarden' }\end{array}$ & $\begin{array}{l}\text { Hondius Boldingh } \\
\text { (GU): Holleman (GU) }\end{array}$ \\
\hline $1915(1926)$ & $\begin{array}{l}\text { meelbleking; } \\
\text { productdifferentiatie }\end{array}$ & $\begin{array}{l}\text { Noury \& Van } \\
\text { der Lande }\end{array}$ & $\begin{array}{l}\text { Böeseken (THD): } \\
\text { Reinders (THD) }\end{array}$ \\
\hline $19 \cdot 16$ & $\begin{array}{l}\text { productdifferentiatie } \\
\text { os.s. wo I }\end{array}$ & "Vondelingenplaat' & $\begin{array}{l}\text { Hoogewerf (THD); } \\
\text { eobeseken (THO) }\end{array}$ \\
\hline 1916 (ca. 1937) & vetharding & Jurgens, Zwijndrecht & $\begin{array}{l}\text { Eojeselken (THD): } \\
\text { Steger (THD) }\end{array}$ \\
\hline 1918 & $\begin{array}{l}\text { scharrste/ nieuwe } \\
\text { technologie (stiks tofl) }\end{array}$ & $\begin{array}{l}\text { Stilistofbindings- } \\
\text { industrie 'Nederland' }\end{array}$ & Reinders (THD) \\
\hline 1918 & $\begin{array}{l}\text { schaarste/ product- } \\
\text { differentiatie (stikstof) }\end{array}$ & ASF (later Albatros) & $\begin{array}{l}\text { Kruyt (RUU); } \\
\text { Ketelaar (GU) }\end{array}$ \\
\hline $1921(1925)$ & $\begin{array}{l}\text { nileuwe technologie } \\
\text { (viscose-rayon) }\end{array}$ & Enhat & Holleman (GU) \\
\hline $1921(1928 ?)$ & vetharding? & Van den Bergh & Wateman (THD)? \\
\hline $1923 / 428$ & nieuw product & $\begin{array}{l}\text { Organon } \\
\text { (Lab Laqueur in GU) }\end{array}$ & Laqueur (CU) \\
\hline $1924(\operatorname{tg} 39)$ & $\begin{array}{l}\text { nietuwe technologie: } \\
\text { (celluloselakken) }\end{array}$ & Silkikens & $?$ \\
\hline 1925 & $\begin{array}{l}\text { neuwe technologier } \\
\text { concurrentie? }\end{array}$ & $H K$ & Kruyt (RUU) \\
\hline 1926 & octroostrigid & $\begin{array}{l}\text { Van der Grinten } \\
\text { (Lab in THD) }\end{array}$ & $\begin{array}{l}\text { Büeseiken (THD); } \\
\text { Verkade (THO) }\end{array}$ \\
\hline $1928(1939)$ & $\begin{array}{l}\text { expansise + opleiding } \\
\text { personeell + milleu }\end{array}$ & Statatsmijnerk & $\begin{array}{l}\text { Michels (GU): } \\
\text { Waterman (THD) }\end{array}$ \\
\hline $\begin{array}{l}1929 \text { (woor- } \\
\text { loper: } 1804 \text { ) }\end{array}$ & $\begin{array}{l}\text { productdifferentiatie } \\
\text { (4884: opkomst } \\
\text { mierobiologie) }\end{array}$ & $\begin{array}{l}\text { Gist-en Spiritus- } \\
\text { Fabiriek, Delft }\end{array}$ & $\begin{array}{l}\text { Bejerinek (THO) } \\
\text { Kluywer }(T H \mathrm{O})\end{array}$ \\
\hline
\end{tabular}


kleurstofindustrie dan kunnen we Heinz Woltereck alleen maar gelljk geven."

Toen zijn proefschrift in 1927 werd gepubliceerd, was de situatie echter drastisch aan het veranderen. Internationaal opererende bedrijwen als Shell, Philips en Enka hadden direct te maken met concurrenten die soms over grote researchorganisaties beschikten. Alle drie besloten ze in de loop van de jaren twintig de schaal van hun researchactiviteit aanzienlijk op te voeren. Phillips beet het spits af. in 1923 verhuisde de Nat.Lab-organisatie naar een groot nieuw laboratoriumcomplex met bijbehorende proeffabrieken, terwijl tegelijkertijd grote aantallen

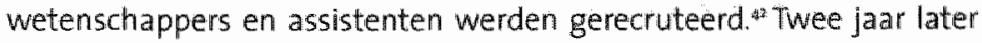
volgde de Enka. Het bedrijf bouwde een nleuw centraal researchlaboratorium met proeffabrieken in Arhem, terwijl tevens het laboratorium bij de fabriek in Ede aanmerkelijk werd vergroot. In 1926 bouwde ook Noury \& Van der Lande een nieuw researchlaboratorium in Deventer, voorzien van een uitgebreide staf. ${ }^{43}$ Weer een jaar later besloot de Koninklijke/ Shell op grote schaal in de chemie te gaan. Het BPM-laboratorium in Amsterdam werd zeer fors uitgebreid en een grote chemische afdeling onder leiding van de voormalige laboratoriumchef van "Vondelingenplaat", Van Peski, opgericht. Tegelijkertijd richtte het concern in Emeryville in Californië een tweede researchiaboratorium op ${ }^{44}$

Aangezien ook andere bedrijven hun researchorganisatie aan het eind van de jaren twintig fors vergrootten leek de situatie in 1930 nauwelijks meer op die van tien jaar daarvoor. Op het BPM-laboratorium in Amsterdam werkten toen inmiddels ruim 500 personen, op het Philips Nat.Lab. bijna 400 en op het centrale AKU-laboratorium in Arnhem ongeveer 60 , maar dat bedrijf had daarnaast ook researchlaboratoria in Duitsland en Amerika en een klein onderzoekslaboratorium in Breda. ${ }^{45}$ in de jaren dertig zette de groei door. In 1940 was het BPM-laboratorium in Amsterdam inmiddels een gigantische 'onderzoeksfabriek' waar 1350 mensen werkten. Het Philips Nat.Lab. telde rulm 500 medewerkers. Samen namen deze twee laboratoria, die zich als enige met grote buitenllandse laboratoria konden meten, toen ongeveer wijftig procent van alle Nederlandse Industriële R\&D-uitgaven voor hun rekening. ${ }^{4 B}$ Hierna volgden de laboratoria van AKU met 150, dat van Gist met 90, het nog in opbouw zijnde Centrale Laboratorium van Staatsmijnen met 80 en het laboratorium van Unilever in Zwijndrecht met ruim 30 medewerkers (zie tabel 2). Al deze bedrijven hadden daarnaast uiteraard ook fabriekslaboratoria, die soms niet veel kleiner waren. Bij Staatsmijnen bijvoor- 
beeld, werkten er begin 1938 bijna 60 personen in het laboratorium bij de Cokesfabriek Emma en bijna 50 in het laboratorium van het Stikstofbindingsbedrijf, terwijl er daarnaast ook een Centraal Proefstation was voor het ondergrondse bedrijf. ${ }^{4}$

Tabel 2: De persaneelsbezetting van de grootste Nederlandse industriefle researchlaboratoria in 1940.

\begin{tabular}{|l|c|}
\hline Laboratorium & Aantal medlewerkers \\
\hline BPM-laboratorium Amsterdam & 1350 \\
Natuurkundig Laboratorium Philips & 516 \\
Onderzoekingsinstituut 'Research'AkU & 150 \\
Laboratorium Gist- en Spiritusfabriek & 90 \\
Centraal Laboratorium Stalatsmijnen & 80 \\
Vereenigde Oliefabrieken Zwijndrecht (Unilever) & $30(1937)$ \\
\hline
\end{tabular}

Daarnaast vond er ook groei in de breedte plaats. In een studie van de Amerikaanse industriële research in het interbellum constateerden David Mowery en Nathan Rosenberg dat research welhaast een modeverschijnsel werd. Tussen 1919 en 1936 richtten meer dan 1000 bedrijven in de Verenigde Staten researchlaboratoria op. Geen zichzelf respecterend bedrijf kon achterblijven. ${ }^{49}$ Ook de ontwikkeling in Nederland begon in de jaren dertig trekken te vertonen van deze enigszins modieuze ontwikkeling. Een van de meest sprekende woorbeelden is de oprichting van het centrale researchlaboratorium van Staatsmijnen, waartoe eind 1937 of begin 1938 werd besloten op initiatief van Frederik van Iterson, de technisch-directeur van het bedrijf. In het archief van DSM, hier in Maastricht in het Rijksarchief gedeponeerd, bevindt zich een do5sier met persoonlijke aantekeningen van van Iterson uit de zomer van 1936 toen hij zich in deze materie ging verdiepen. Het meest opvallende aan die aantekeningen is dat er helemal geen dwingende redenen in staan waarom Staatsmijnen de research zou moeten intensiveren. Het zijn steeds opmerkingen in de trant van: ik was onlangs bij de Gasstichting, hoorde daar een lezing over het belang van research en 'ben getroffen door de krachtige en juiste argumenten." Of, na het boek Glances at Industrial Research gelezen te hebben, de natitie: 'De research-laboratoria in Amerika schynen aldaar de industrie in den laatste tyd snel vooruit te brengen.' Ook de wonderbaarlijke technische ontwik- 
keling van Rusland was, zo meende hij, "voor een groot deel te danken aan de voortreffelijke organisatie van het "researchwerk". Na een bezoek aan bedrijven in Canada en de Verenigde Staten, aan het Philips Nat. Lab. en mogelijk ook aan andere Nederlandse laboratoria te hebben gebracht, hakte Van Iterson de knoop door: "The cost of not doing it" zou groter blijken te zijn, dan de investering in een grote researchorganisatie - Staatsmijnen moest ook zoliets fraais hebben. . $^{\circ}$

Bij de chemische fabriek van het Groningse Scholten-concern, groot op het gebied van aardappelmeel en strokarton, speelden vergelijkbaar vage overwegingen een rol. De daar werkzame technisch-directeur F.A. Möller had daarvóór als colorist bij de grote katoendrukkerij van Fentener van Vlissingen in Helmond gewerkt en was daar via werhalen van handelsreizigers en de literatuur op zijn gebied onder de indruk geraakt van de prestaties van de kleurstoflaboratoria van IG Farben. Hoewel hier, zou ik willen zeggen, in feite een mug met een olifant werd vergeleken, vormde het succes van de Duitse industrie voor Möller een belangrijke prikkel zelf in 1938 aok zo'n laboratorium op te richten." Ongetwijfeld waren er meer bedrijwen in die tijd die op vergelijkbare wijze als het ware 'op de tast' tot het besluit kwamen een laboratorium op te richten. Waar de grotere bedrijven in de jaren twintig waren woorgegaan, zetten nu ook verschillende middelgrote bedrijven die stap. Naast Scholten ging het daarbij bijvoorbeeld om de verffabrieken Sikkens (1924, sterk vergroot in 1939) en Pleter Schoen (1931, sterk vergroot in 1942) en in de farmaceutische hoek om Philips-dochter Duphar (1937), de Amsterdamsche Chinine Fabriek (1939) en Organon (1938). ${ }^{\text {.a }}$

$\mathrm{Na}$ dit overzicht van de opkomst van industriële research in Nederland is het tijd voor een pas op de plaats. Ik heb drie aandachtspunten geformuleerd:

- betreffende de periodisering

- betreffende de contacten tussen laboratoria onderling en tussen de industrie en het hoger onderwijs, en

- betreffende het al dan niet 'tastende' karakter van beleidsbeslissingen.

Het eerste en het derde punt laten zich gemakkelijk samenvalten. Industrièle research kwam in Nederland in een betrekkelijk korte periode van dertig jaar (ca.1909-1939) van de grond en de overwegingen die daarbij een rol speelden waren, zoals de voorbeelden uit de Eerste Wereldoorlog en die van de BPM en Philips, laten zien, sterk ingegeven 
door de economische situatie van het bedrij, zoals optredende concurrentie en het niet voorhanden zijn van bepaaide technische kennis. In andere gevallen echter speelde ook een me too-element een rol: andere bedrijuen doen het, dus het moet wel goed zijn.

\section{Het Nederlandse R\&D-netwerk (I)}

Bi] het opzetten van hun researchorganisatie leerden bedrijuen van ekaar. De BPM huurde, zoals vermeld, de voormalige onderzoeksleider van 'Vondelingenplaat' in om haar chemische research op poten te zetten. Een nog sprekender voorbeeld vormt de Enka, die in 1925 twee ervaren laboratoriumchefs van andere Nederlandse bedrijven aantrok om een krachtige start te maken bij de opzet van een nieuwe researchorganisatie. Eén van hen, lames Polak, kwam van Phillips, waar hij de leider van het Chemische Laboratorium was. Aangesteld als 'chef chemicus' in Arnhem rustte op hem de taak de coördinatie tussen cle research en de fabrieken te bewerkstellingen. Na de fusie, in 1929, van de Enka met het Duitse Glanzstoff-concern en de Hollandsche Kunstzijde-Industrie ( $\mathrm{HKI})$ uit Breda, tot de Algemeene Kunstzijde Unie (AKU), klom Polak ap tot de positie van hoogste baas van de gemeenschappelijke research. In 1933 werd hiertoe een aparte naamloze vennootschap opgericht, met de omineuze naam N.V. Onderzoekingsinstituut 'Research', dat het centrale laboratorium van de AKU in Arnhem onder haar beheer kreeg, met Polak als directeur. In maart 1940 vertrok hij juist op tijd naar Amerika, om daar de researchleiding van American Enka op zich te nemen. ${ }^{53}$

De andere laboratoriumleider die men aan zich wist te binden was Jan Uytenboogaart, de chef van het chemische laboratorium van de Cokesfabriek van Staatsmijnen. Hij kreeg het laboratorium in Ede onder zijm beheer. Binnen de AKU ontwikkelde hij zich tot een allround-kenner van de kunstzijde-industrie en vervulde hij verschillende leidinggevende technische functies in Amerika en Europa, waaronder die van directeur van het Forschungs-Institut van Glanzstoff bij Berlijn. In 1937, toen de Koninklijke/ Shell steeds meer aandacht kreeg voor synthetische vezels en kumststoffen, stapte hij over naar de BPM en klom daar uiteindelijk op tot hoogste baas van alle chemische activiteiten van dat bedriff.,

De voorbeelden van Polak en Uytenboogaart illusteren fraai hoe ervaringen opgedaan in het ene bedrijf overgeplant werden in een nieuwe situatie, om daar verder te worden ontwikkeld. ${ }^{55}$ In het vervolg van mijn verhaal zal ik u hiervan enkele nog sterkere woorbeelden geven. 


\section{De rol van de universiteiten}

De uniwersiteiten kwamen tot nu toe slechts zijdelings ter sprake, toch was hun rol verre van marginaal. Voor de industrie was het contact met hoogleraren van groot belang. Bovenal vanwege de recrutering van nieuwe researchmedewerkers, maar daarnaast ook om in algemene zin op de hoogte blijven van wat zich op wetenschappelijk gebied afspeelde en soms ook om heel gericht bepaalde expertise in te huren die men zelf niet bezat. Vrijwel steeds waren daarom hoogleraren als adviseur of commissaris aan de tot nu toe besproken bedrijven verbonden. Als variant op 'cherchez la femme' is 'cherchez le professeur' een onderzoeksstrategie waarbij succes is gegarandeerd. Hoe dieper men in de archieven duikt, vroeg of laat komt men ze altijd tegen. Het omgekeerde is echter niet het geval: wie de levenslopen van natuurwetenschappelijke hoogleraren onderzoekt zal lang niet altijd bij bedrijven uitkomen. Er is hier sprake van een duidelijk asymmetrie. Bedrijven onderhielden bijna altijd contacten met hoogleraren, maar men komt daarbij in de jaren voór de Tweede Wereldoorlog vaak dezelfde namen tegen; Delftse hoogleraren als Steger, Waterman, Reinders, Scheffer en Kluyver; Utrechtse hoogleraren als Ornstein, Kruyt, Kögl en Koningsberger; Amsterdamse professoren als Holleman, Wibaut, Hondius Boldingh, Laqueur en Michels; en De Jongh en Ehrenfest uit Leiden (vgl. tabel 1). Hoewel de groep hoogleraren die contacten met de industrie onderhield bepaald niet klein is, kan het feit dat grote groepen ook géén contacten onderhielden wellicht verklaren waarom in sommige kringen het beeld van de ivoren taren zich zo hardnekkig kon handhaven.$^{5 \overline{6}}$

Dat de contacten tussen industrie en universiteit soms zeer intensief konden zijn illustreert het woorbeeld van de opvolger van Steger in Delft, Hein Waterman. Deze was vanaf 1927 adviseur van de BPM, wat ondermeer inhield dat er op kosten van de BPM enkele assistenten op zijn lab werden aangesteld die onderzoek deden op terreinen die voor de BPM relevant waren. Over dat onderzoek, maar ook over andere kwesties die hij van belang achtte, rapporteerde hij regelmatig aan het researchlaboratorium in Amsterdam en aan de technische afdelingen in Den Haag. Volgens mensen die hem hebben gekend, was Waterman een uiterst energiek man en wie de omvangrijke 'Waterman-dossiers' in het Shellarchief in Den Haag bestudeert kan tot geen andere conclusie komen. Jarenlang schreef hij vele tientallen rapporten per jaar, soms zelfs twee in één week. Dit alles naast zijn vele verplichtingen alls hoogleraar, naast enkele andere adviseurschappen en naast een meer dan gemiddelde publicitaire activiteit. Toen hij in 1959 afscheid nam als hoogleraar ston- 
den er 16 boeken en bijna 600 publicaties op zijn naam. Nadat het Britse ICI hem een aanbod had gedaan om door hem gedane vindingen tegen betaling over te nemen, haalde hij in 1934, met het oog op het nationaal belang, zo schreef hij het College van Curatoren, de banden met de BPM nog strakker aan door een contract te ondertekenen waarin hij toezeg. de al zijn ontdekkingen, 'ook wanneer deze gebieden betreffen; die buiten de eigenlifke petroleumindustrie liggen' over te dragen aan dat bedriff. 'Door jarenlange ervaring is mil gebleken, dat er hier te lande, behalve de B.P.M. geen maatschappi] is, die over voldoende hulpmiddelen van technischie en wetenschappelijke aard beschikt, om in staat te zijn naar behoren het verwerken wan algemeene vindingen tot industrieele processen geheel te kunnen doorzetten: De minister van Onderwijs, Kunsten en Wetenschappen, aan wie Curatoren de kwestie hadden voorlegd, stemde in met het contract, onder de toevoeging dat bij het doen wan vondsten geen gebruikt zou mogen gemaakt van 'Rijksinrichtingen en hulpmiddelen' op een wijze die 'ten aanzien van de schatkist niet te verantwoorden zou zijn.' si

Voor de BPM vormden de door hen betaalde Delftse assistenten slechts een kleine aanvulling op hun grote researchcapaciteit in Amsterdam. Voor enkele middelgrote ondernemingen, zoals het venlose bedrijf Océ-van der Grinten lag dit anders. Dat bedrijf had onderzoekers op het laboratorium van de organisch-chemicus Böeseken in Delft ondergebracht en die vormden min of meer de kern van de researchactiviteit vam het bedrijf. Bij Böeseken, die grossierde in adviseurschappen, waren ook onderzoekers van Noury \& Van der Lande en enkelle andere bedrijven gedetacheerd. ${ }^{5 \mathrm{~B}}$

Een nog extremere vorm van samenwerking tussen universiteit en industrie kwam woor bij de farmaceutische bedrijven Organon en Brocades. In die twee gevallen bevond het research-laboratorium zich in feite op de universiteit. Tussen 1923, toen het bedrijf werd opgericht, en 1938 toen er een onderzoeksgroep in Oss werd gevormd, werd het leeuwendeel van de research van Organon verricht op de laboratoria van Errnst Laqueur in Amsterdam en Samuel de Jongh in Leiden.5. ${ }^{59}$ Een vergelijkbare situatie bestond bij Brocades, waar zelfs tot 1959 de meeste researchgroepen zich in universitaire laboratoria bevonden: eerst bij Koningsberger en Bijlsma in Utrecht en later bij Nautal en Duywené de Wit aan de Vrije Universiteit. De researchleider van Brocades, Nauta, had zijn hoofdzetel tot 1959 niet bij het bedrijf, maar aan de $V^{60}$

Met deze voorbeelden van verschillende samenwerkingsvarianten moge hier worden wolstaan. De spreekwoordelijke 'iworen toren' is ver te 
zoeken. Belangrijk is het te constateren dat er un de periode die we hier bespeken wooral een kennisstroom liep van de universiteiten naar de industrie. De aan de universiteiten zeer sterk vertegenwoordigde fasenleer bijwoorbeeld, een onderdeel van de fysische chemie, kwam via leerlingen van de hoogleraren Schreinemakers in Leiden en Scheffer in Delft ook bij bedrijven als de BPM en Staatsmijnen terecht en droeg daar bij aan de opbouw van enkele zeer sterke posities op sommige technische terreinen. Bij de BPM ging het daarbij om scheidingstechnologie en bij Staatsmijnen om de productie van kunstmest. Tijdens de Tweede Wereldoorlog deed Scheffers'leerling Jean Plusjé bij Staatsmijnen fundamenteel fasentheoretisch onderzoek op het gebied van de productie van mengmeststoffen.Dat leverde Staatsmijnen een succesvol industrieel proces op en Plusjé zijn proefschrift, waarop hij in 1946 bij Scheffer promoveerde. Plusjé wijdde ook zijn van de HTS afkomstige assistent Piet Kaasenbrood in de geheimen van de fasenleer in. Eind jaren vijftig lukte het Kaasenbrood op basis van diepgaand fasentheoretisch onderzoek een geheel nieuw procédé voor de productie van ureum te vinden dat tot de meest succesvolle processen van Staatsmi]nen (later DSM) behoort. Meer dan noo licenties op dit proces werden over de gehele wereld verkocht.".

\section{Hoge verwachtingen van fundamentele research}

$\mathrm{Na}$ de Tweede Wereldoorlog liep de kennisstroom steeds vaker de andere kant op: van de industrie naar de universiteit. Toen industriële laboratoria meer onderzoek gingen doen, betraden ze steeds vaker terreinen waarover aan de universiteiten nauwelljks kennis bestond. Dit gebeurde vooral op voor de industrie relevante interdisclplinaire gebieden die aan de langs klassieke disciplinaire lijnen verkavelde universiteiten niet goed aan bod kwamen. Op het gebied van de natuur wetenschappen waren dat bijwoorbeeld de vaste-stoffysica en vastestofchemie, de fysica en chemie van polymeren, en de katalyse. Ook op terreinen waarvoor dure apparatuur nodig was, zoals de molecuulspectroscopie en de instrumentele analyse, verkreeg het industriele onderzoek in de jaren vijftig een voorsprong. Terwijl voor de Tweede Wereldoorlog eigenlijk alleen Philips enige hoogleraren had geleverd voor leerstoelen aan de TH in Delft, veranderden de verhoudingen na de oorlog radicaal. ${ }^{62}$ Toen in de jaren zestig ook op de genoemde nieuwe terreinen leerstoelen aan de universiteiten werden gecreëerd, werden deze wrijwel uitsluitend door wetenschappers met een industriecarrière bemand. De vaste-stoffysica en vaste-stofchemie in Nederland 
werd wolledig gedomineerd door anderzoekers van Philips, leerstoelhouders op het gebied de katalyse en moleculilspectroscopie kwamen woornamelijk van Shell en in mindere mate DSM. Op het gebied van de polymeerchemie leverden AKU (later Akzo) en DSM de hoogleraren; Unillever deed hetzelfde op bijwoorbeeld het terrein van de instrumentele analyse. Voor alle duidelijkheid, het gat hier om de bendeming van gewone hoogleraren. Dat de na de oorlog eveneens op ruime schaal benoemde buitengewone hoogleraren banden met de industrie hadden spreekt haast vanzelf.

Hoe was het mogelijk dat de verhoudingen zich na de Tweede Wereldoorlog zo konden wijzigen? Twee factoren zijn reeds genoemd: industriële relevantie en financiële armslag. Toch zijn deze verklaringen onvoldoende. Om het plaatje compleet te maken moeten we ook de vraag stellen waarom de industriële laboratoria zoveel professorabele lleden opleverden die blijkbaar in die industrie onderzoek hadden gedaan dat ook in universitaire kring van voldoende niveau werd geacht. Daarnaast moeten we zien te begrijpen waarom de universiteiten bereid waren leerstoelen in te stellen op interdisciplinaire terreinen met industriêle relevantie. $\mathrm{lk}$ begin met de eerste vraag.

Dat er excellent natuurwetenschappelijk onderzoek verricht werd in de grote industriële laboratoria lijdt geen twijfel. Voor een boek over de ontwikkeling van de Nederlandse scheikunde na 1945, dat ik samen met mijn Utrechtse collega Lodewijk Palm redigeer, heb ik een analyse gemaakt van de institutionele herkomst van 147 Nederlandse 'toponderzoekers" op het gebied van de chemie, waarbij ik als indicator genomen heb alle winnaars van belangrijke Nederlandse wetenschapsprijzen op het gebied wan de chemie sinds. 1945, aangevuld met de 'chemische leden' van de Koninklijke Akademie van Wetenschappen, ${ }^{64}$ Dat levert een verrassend beeld op. Wanneer we het gehele chemische onderzoek in beschouwing nemen, staan drie van de klassieke universiteiten - Utrecht, Leiden en Groningen - bovenaan, op de hielen gevolgd door Shell en de Universiteit van Amsterdam. Elk van deze instellingen ult de kopgroep had in de periode na 1945 zo'n 14 tot 22 full time toponderzoekers. ${ }^{\text {ss }}$ Dan volgt een middenmoot, met elk 5 tot 10 full time toponderzoekers, die bestaat uit. Philips, TH Delft, DSM, Akzo en de LH Wageningen. Andere universiteiten, TNO, het NKI en Unilever zitten in de staartgroep (tabel 3 ). 
Tabel 3: Instellingen met chemische toponderzokers; sinds 1945

\begin{tabular}{|l|c|c|}
\hline Instelling & Total zonder biochemie & Totaal ind: biochemie \\
\hline RUU & 7,5 & 22,0 \\
RUL & 8,0 & 19,0 \\
RUG & 10,0 & 17,5 \\
Shell & 15,5 & 15,5 \\
UvA & 10,5 & 14,5 \\
Philps & 8,5 & 9,5 \\
THD & 7,5 & 8,0 \\
DSM & 5.5 & 6,0 \\
Akzo & 5,5 & 6,0 \\
LHW & 2,0 & 5,0 \\
THE & 3,0 & 3,0 \\
TNO & 1,0 & 3,0 \\
KUN & 1,5 & 2,5 \\
NKt & 0,0 & 2,5 \\
Overige (ind. & 6,5 & 11,0 \\
buitenlandse instel.) & & \\
\hline Total & 92,5 & 147,5 \\
\hline
\end{tabular}

Toellchting: personen die aon 2,3 of 4 instellingen heb gewerkt, zijn per instelling geteld woor $0,5,0,33$ resp. 0,25. Alle tatalen zijn wervolgens afgerand op hele en halve ciffers. Hierdoor komt het totaal wit op 147.5 1.p.k. 147. NKI $=$ Nederlands Kankerinstiturt.

Wanneer we dezelfde exercitie nogmaals uitvoeren, maar nu zonder de biochemie - een vak dat gedurende het grootste deel van de betreffende periode veel sterker tegen de medische wereld aanleunde dan tegen de industrie - dan wordt de vooraanstalande positie van hat industriële onderzoek op het gebied van de chemie nog overtuigender. Shell staat met 15 à 16 full time toponderzoekers ruim bovenaan. De middenmoot bestaat nu, in afnemende volgorde, uit de universiteiten in Amsterdam en Groningen, Philips, de universiteiten in Leiden, Utrecht en Delft, DSM en Akzo. De universiteiten in Utrecht, Leiden en Groningen danken hun hoge klassering in de eerste telling voor een groot deel aan hun omvangrijke en hoogstaande biochemische onderzoek. Kijken we in 
het bijzonder naar de industrie dan zien we bij Philips 8 à 9 full time toponderzoekers in deze telling en bij DSM en AkzO 5 aे 6 . Het beeld van Philips is wat wertekend, omdat het in dit overzicht alleen om chemisch onderzoek gaat, terwijl het Philips Nat.Lab, de naam zegt het al, ook zeer sterk is op het gebied van de fysica.

Tot zover dit Quote-achtige inkijkje in de Nederlandse chemie. $k$ ben me uiteraard bewust dat er enorm veel op dit soort tellingen is af te dingen, evernals op de verlening van wetenschapsprijzen, waar immers Mertons 'Mattheus-effect' een rol speelt en waar ook vriendjespolitiek nooit geheel is uit te sluiten. Het gaat echter wel om vele tientallen persanen, en de verschillen tussen sommige instellingen zijn groot. Dat de industriêlle laboratoria zich in zo'n rangorde midden tussen de universiteiten nestelen, op een schaal die niet primair door toepassingen maar door wetenschappelijke kwaliteit wordt bepaald, blijft een opvallend gegeven.

Dit is alleen maar te verklaren als we aandacht hebben voor het feit dat er birnen de industriële laboratoria ook fundamenteel onderzoek werd gedaan. Dat industriële researchlaboratoria dat zouden moeten doen is niet vanzelfsprekend. Integendeel. Toen in de jaren zeventig en tachtig van de negentiende eeuw de industriële research in de Duitse kleurstofindustrie van de grond kwam was er al snel sprake van 'wissenschaftliche Massenarbeit' "Lopende-bandwerk kortom, waarbij chemici duizenden verbindingen synthetiseerden, die vervolgens in ververijen of met behulp wan proefdieren op hun kleurstofkwaliteiten of farmaceutische eigenschappen werden getest. 'Von Gedankenblitz keine Spur', zo typeerde Bayer-directeur Carl Duisberg het werk dat in de laboratoria van zijn bedrijf werd gedaan - in een context overigens, het moet worden gezegd, waarin hij zijn chemici een toontje lager wilde laten zingen met betrekking tot het claimen van hoge tantièmes op hun uitvindingen. Ondanks deze relativering moge het duidelijk zijn dat de wissenschaftiche Masseriarbeit in de eerste industriële laboratoria ver afstond van onderzoek warmee je lid van een Akademie van Wetenschappen kunt worden. Blijkbaar kreeg het researchwerk in de loop van de tijd een ander karakter.

De oorsprong van die omslag wordt niet zelden gelegd bij het invloedrijke rapport Science the Endless Frontier dat Vannevar Bush, hoogleraar ellectrotechniek aan het prestigieuse MIT, in 1945 aanbood aam president Roosevelt. In dat rapport betoogde hij, op grond van de ervaringen met de wetenschap in het Manhatten-project en andere grote projecten gedurende dle Tweede Wereldoorlog, dat basic science, 
fundamenteel onderzoek "de grondslag vormde voor belangrijke doorbraken. Een land dat zijn basic science verwaarloosde zou op den duur hopeloos achter raken en de concurrentieslag met andere landen op economisch en militair gebied verliezen. ${ }^{6}$

Nu zou ik zeker niet willen beweren dat het rapport van Bush zonder invloed was. Het was invloedrijk in Amerika en alleen al daarom indirect ook in Nederland. Een directe invloed was er ook. Op het eerste congres in Nederland dat toegespitst was op industriele en landbouwkunde 'Research', gehouden in Utrecht in oktober 1947, werd er zowel door congreswoorzitter Twijnstra als door de key-note speaker Gilles Holst van Philips nadrukkelijk aan het rapport van Bush gerefereerd. Toch geeft deze nadruk op het rapport van Bush een verkeerd beeld van het vooroorlogse onderzoek en een te eenzijdig. Amerikaans, beeld van de ral van de Tweede Wereldoorlog. ${ }^{58}$

Fundamenteel onderzoek begon in de industrie namelijk al aan het begin van de twintigste eeuw. Willis Whitney en zijn medewerker Irvin Langmuir bij General Electric, die voor zijn onderzoek bij GE in $193^{2}$ de Nobelprijs kreeg, namen het voortouw. ${ }^{69}$ in de jaren twintig volgde ook de chemische industrie. In 1926 besloten onderzoeksleiders van de Duitse chemiegigant IG Farben - een bedrijf dat toen met meer dan 3700 researchmedewerkers op een geheel andere schaal opereerde dan de Nederlandse industrie - om twee onderzoeksgroepen te formeren die fundamenteel onderzoek zouden doen op het terrein wan de polymeerchemie en de katalyse. Vrijwel tegelijk startte ook het grote Amerikaanse chemische bedrijf Du Pont een programma gericht op 'pure science or fundamental research. Het was als ondercleel van dat programma dat een aantal jaren later de synthetische vezel nylon werd ontdekt. Die ontdekking was zo'n succes en sprak zo tot de verbeelding dat dit zowel binnen Du Pont als daarbuiten als een krachtig bewijs werd gezien woor het doen van fundamenteel onderzoek in een

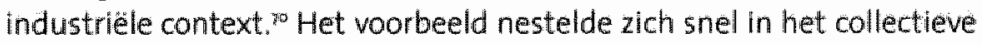
bewustzijn van wetenschappers en technici die zich met onderzoeksbeleid bezig hielden. Tot op de dag van vandaag kan de 'nylon-mantra' regelimatig worden gehoord." Net als in het woorbeeld van Van Iterson dat ik gaf, zou ik het gebruik van het nylon-voorbeeld in beslissingen over research als "beleid op de tast' willen typeren. Daarbij doemt een beeld op van een kruising tussen het spelen van blindemannetje en het uitvoeren van een polonaise. De deelnemers, die allen zijn geblinddoekt, volgen elkaar op de tast. 
In Nederland was het met name Holst bij Philips die een grondige wetenschappelijke a anpak propageerde. 'Het heeft vaak zin', $z 0$ stelde hij in zijn lezing uit 1947, een onderzoek zo fundamenteel mogelijk op te zetten en niet te direct op het doel af te stevenen. Hiermee vergroot men de kans om een nieuwe of betere weg te vinden. De directe weg is meestal door anderen ook al betreden en heeft hen klaarblijkelijk niet het gewenste resultaat opgeleverd. Hoe beter men de verschingelen op de achtergrond beheerst, des te groter de kans om de beste oplossing te vinden (.... ${ }^{\prime 2}$ Dit pleidooi voor een wetenschappelijk omweg, dat academici welhaast als muziek in de oren moest klinken, werd ook door de opvolgers van Holst, Henk Casimir, Evert Verwè en Herre Rinia, wolledig onderschreven. De prestaties die het Nat.lab. tussen 1914 en 1946 onder leiding van Holst had geleverd leken deze filosofie bovendien volledig te bevestigen. Het had geleid tot een grote productdifferentiatie bij Philips, tot een goed gevulde actrooiportefeuille en tot een grote reputatie in de wetenschappelijke wereld. ${ }^{n}$ Twee voorbeelden, die veel opzien baarden, licht lik eruit: de ontdekking van een syntheseroute voor vitamine $D$, en het werk van Anton van Arkel en Jan de Boer op het gebied van de vaste. stofchemie en de chemie van oppervlakken.

Vooral de ontdekking van een bereidingswijze voor vitamine $D$ sprak 20 tot de verbeelding dat Holst in zijn lezing uit 1947 dit voorbeeld als 'kroongetuige' inzette voor zijn researchfilosofie. in $1927 \mathrm{kreeg}$ de fysicus Aart van Wijk op het Nat.Lab de opdracht een UV-hoogtezon te ontwikkelen ter bestrijding van de Engelse ziekte. Holsts 'wetenschappelijke omweg' indachtig beperkte Van Wijk zich niet tot eem rapportage van de zichtbare effecten wan de lamp op patiënten, maar startte hij diepgaand biofysisch onderzoek naar de moleculaire omzettingen in de huid onder invloed van UV-licht. Het was bij dat onderzoek dat ontdekt werd dat er onder invloed van UV-straling in de huid een stof geproduceerd werd, vitamine D, die een gunstig effect op de ziekte had. Dit opende de weg tot een bereiding van die stof in het laboratorium. Nadat van Wijk er samen met de chemicus E.H. Reerink in was geslaagd een economische syntheseroute te ontwikkelen, richtte Philips in 1930 met chocoladefabrikant Van Houten - voor de smaak - de NV Pharmaceutische Productenmaatschappij Philips-Van Houten op, waaruit zich later de farmaceutische dochter van Philips, Duphar (Dutch Pharmaceuticals), zou ontwikkelen. Research bij Duphar verliep geheel volgens de 'filosofieHolst' In de jaren zestig werd maar liefst twintig procent varn de omzet aan research besteed, een ongekend hoog percentage dat alleen kon worden opgebracht door de aanwezigheid van een sterke moeder. Op 
het researchlab in Weesp werkten toen ruim 360 personen, waaronder bijna 60 academici ${ }^{74}$

Van groter belang voor de Nederlandse wetenschapsbeoefening en industrie was het werk dat Van Arkel en De Boer op het Nat Lab. verrichtten. In de jaren twintig deden deze chemici onderzoek naar metalen en andere vaste stoffen, waarbij ze op basis van de recente atoommodellen van Bohr en Kossel een elegante theorie ontwikkelden die het mogelijk maakte op basis van simpele parameters als ionstralen en ladingen een desperate veelheid aan empirische gegevens onder één gezichtspunt te verenigen. Deze theorie, die zij in uitgewerkte vorm in 1930 publiceerden in hun boek Chemische binding als electrostatisch werschijnsel, had voor onderzoekers in het Philips Nat.Lab. een grote heuristische waarde. Het vormde de start van een zeer vruchtbaar onderzoeksprogramma op het gebied van de chemie van de vaste stof dat tot ver na de Tweede Wereldoorlog doorwerkte. Hoewel de directe technische spin-off van de theorie van Van Arkel en de Boer in de literatuur regelmatig is overdreven, zoals Marc de Vries recent heeft laten zien in zijn geschiedenis van het ferrieten-onderzoek bij Philips, speelde het wèl een grote rol in het werk van de toonaangevende Philips-onderzoeker Evert Verwey, de echtgenoot van de minstens zo bekende sociologe Hilda Verwey-Jonker. ${ }^{75}$

Voor de Nederlandse anorganische chemie betekende de studie van deze Philips-onderzoekers een belangrijke, op fysisch-chemische inzichten gebaseerde wending die een radicale breuk betekende met de tot dan toe gangbare uiterst descriptieve werkwijze van dat vak. Dat zulke theoretische studies uit een industrieel laboratorium konden voortkomen geeft op zich reeds aan dat Holst een bijzondere academische sfeer op zijn laboratorium had weten te scheppen. ${ }^{76}$ De 'publication-records' van Van Arkel en De Boer vormen daarvan een extra illustratie. Zij onderstrepen zowel het uiterst liberale beleid van Holst op dat punt, als de productiviteit van hun onderzoek. Toen Wan Arkel in 1934 hoogleraar in Leiden werd, had hij reeds bijna 100 publicaties op zijn naam staan, die bijna alle uit zijn werk op het Nat. Lab. waren woortgekomen, en toen De Boer vijf jaar later bij Philips vertrok stonden er 150 publicaties achter zijn naam." De praktijk in de negentiende eeuwse Duitse kleurstofindustrie en in de laboratoria van margarinefabrikant Jurgens, waar publiceren van onderzoeksresultaten 'out of the question was," staat hiermee in schril contrast. ${ }^{8}$

Toen Van Arkel in 1934 als opvolger van Schreinemakers in Leiden aantrad was hij daarmee een van de eerste hoogleraren scheikunde in 
Nederland die afkomstig was uit het bedrijfslewen. Anders dan voor verschillende van zijn collega's was voor Van Arkel samenwerking met de industrie heel normaal. Net als Kruyt in Utrecht, verzamelde hij weldra een enthousiaste groep leerlingen om zich heen, waarvan er velen later op sleute posities terecht zouden komen in het industriële onderzoek: Van Krevelen, later research-directeur bij Staatsmijnen en bij Alkzo, Böttcher, later research-adviseur van shell en een van de grondleggers van het Nederlaindse wetenschapsbeleid, Schuit, leider wan de research op het gebied van de heterogene katalyse bij Shell, en Staverman, jarenlang chef van het fundamentele polymerenonderzoek bij TNO. Aangezien Van Arkel zijn in Eindhoven gestarte onderzoeksprogramma in Leiden in wezen voortzette spreekt het haast wanzelf dat veel van zijn leerlingen later bij Philips terecht kwamen. Minder bekend is dat zijn leerlingen George Schuit en Piet Cossée inzichten ontleend aan de vaste-stofchemie introduceerden in het katalyse-onderzoek bij shell en daarmee bijdroegen aan de intermationaal dominante positie van het Amsterdamse Shell-laboratorium op dat terrein - een fraai staaltje indi. recte kruisbestuiving tussen het onderzoek bij Philips en Shell. ${ }^{\text {T9 }}$

Ook De Bioer had een invloed op de Nederlandse industriële research die veel verder reikte dan de muren van het Nat.Lab. Nog bij Phillips, publiceerde hij in 1935 een overzichtswerk over Electron emission and adsorption,waarvan Schuit later schreef dat dit het belangrijkste vooroorlogse boek in Nederland was over de grondslagen van de heterogene katalyse hoewel het woord katalyse in het hele boek niet voorkwam. Tijdens de mobilisatie in 1939 kreeg De Boer de leiding over het Centraal Laboratorium woor Defensievraagstukken. $\mathrm{Na}$ in mei 1940 net op tijd naar Engeland te zijn ontsnapt, leidde hij gedurende de oorlog een klein laboratorium van de regering in ballingschap in Londen. $\mathrm{n}$ die tijd kreeg hij ook contact met de Britse tak van Unilever. Toen dat bedrijf na de oorlog haar research sterk wilde intensiveren en reorganiseren, vond men De Boer bij uitstek geschikt om, voortbouwend op zijn ervaringen bij Philips, toe de treden tot de researchleiding in Port Sunlight. In 1950 verruilde hij zijn leidinggevende functie bij Unilever voor die van wetenschappelijk adviseur van de directie van Staatsmijnen ${ }^{\text {so }}$ Naast zijn baan als Ressearchleider van Unilever en, later, adviseur bij Staatsmijnen, werd De Boer in 1946 tot buitengewoon hoogleraar in Delft benoemd. Hij koos de katalyse als werkterrein en werd daarmee de eerst hoogleraar op dat gebied in Nederland. Ondanks het feit dat hij als buitengewoon hoogleraar slechts een deel van zijn tijd aanwezig was, lukte het hem een zeer productieve onderzoeksgroep op te zetten, die als de "Dutch 
School of Catalysis. ook in het buitenland een grote naam kreeg. Fen groot deel van de katalytici in het bedrijfsleven en de universiteiten zijn voortgekomen uit de school van De Boer.

\section{Het Nederlandse R\&D-netwerk (II)}

Ik heb wat lang stilgestaan bij dit voor insiders wat afgekloven voorbeeld van het werk van Van Arkel en De Boer omdat het bij uitstek mijn tweede aandachtspunt - dat vain de wisselwerking tussen bedrijven en universiteiten - illustreert. Het laat zien hoe er tal van verbindingen ontstonden, zowel sociaal als cognitief, tussen Philips, Shell, Unilever en Staatsmijnen. En ook tussen deze bedrijuen en de universiteiten in Leiden en Delft. $U$ ziet dat ik er de voorkeur aan geef om Nationale Innovatiessystemen niet als een abstracte notie te behandelen, maar als iets dat heel concreet voortkomt uit het handelen van mensen.

Een tweede punt dat met dit voorbeeld kan worden geillustreerd, is hoe de onderzoeksfilosofie van Holst kon doorwerken in het beleid van andere industriële laboratoria. Dàt dit gebeurde is zeker het geval. Bij Staatsmijnen waren directeur van Iterson en de researchleider Gé Berkhoff grote bewonderaars van de aanpak van Holst. Toen tussen 1938 en 1940 het nieuwe Centraal Laboratorium van Staatsmijnen werd opgericht was daarbij het Nat.Lab. het grote woorbeeld. ${ }^{8:}$

Ook andere bedrijven gingen er al vóór of in de oorlog, dus voorafgaand aan het rapport van Vaminevar Bush, toe over om de fundamentele research in hun bedrijf te versterken. Het meest sprekende voorbeeld wordt gevormd door de AKU, die in 1941 besloot een fundamenteelgericht Instituut voor Cellulose-Onderzoek in Ultrecht te vestigen bewust ver weg van de op praktijkproblemen gerichte researchlaboratoria in Arnhem en dicht bij de groep van Kruyt op de Utrechtse universiteit. Kruyt, die al sinds 1924 commissaris en adviseur van de HKI was, was sinds de oprichting in 1933 ook lid van de Raad van Bestuur van de NV Onderzoekingsinstituut 'Research', het bedrijf waaronder het Instituut voor Cellulose-Onderzoek ressorteerde. Nadat het Utrechtse instituut in 1943 van start was gegaan ontwikkelde het zich tot een van de belangrijkste onderzoeksinstituten op het gebied van polymeren. Van de eerste generatie hoogleraren polymeerchemie in Nederland kwamen er verschillende van dit instituut. ${ }^{\text {Bg }}$

Dat het Institu ut voor Cellulose-Onderzoek midden in de oorlog werd opgericht was geen toeval. Verschillende bedrijven deden er allies aan om hun researchmedewerkers zoveel mogelijk aan het werk te houden, desnoods met fundamentele, of zelfs met geheel nutteloze, onderzoe- 
kingen, om zo te voorkomen dat die medewerkers als onderdeel van de Arbeitseinsatz in Duitsland tewerk zouden worden gesteld. Zeer instructief is de vergelijking van de totaal verschillende wijzen waarop Philips en de BPM dit vraagstuk tijdens de oorlog aanpakten. Wat er precies gebeurde en wat voor invloed dit na de oorlog had is nog nooit systematisch onderzocht. Ik denk dat er een prachtig proefschriftonderwerp in zit: als de betrokken bedrijven tenminste willen meewerken.

De BPM en Philips stonden tijdens de oorlog voor geheel werschillende problemen. Door de Duitse inval in mei 1940 raakte de BPM plots afgesneden van de rest van het wereldconcern en wan vrijwell al haar grondstoffen. Dit betekende dat het grote research-instituat in Amsterdam, met 1350 medewerkers, en de grote technische diensten en ingenieursbureau's in Den Haag in figuurlijke zin geheel in de lucht hingen. Wachtgeld, werkloosheid, tewerkstelling in Duitsland en een 'gat' in de leeftijd sopbouw van het personeel dreigden. Tegen deze achtergrond kwam de op het Amsterdamse BPM-lab werkzame scheikundige Dolf Kohnstamim in 1940/41 op het idee om het personeel zoveel mogelijk in dienst te houden en uit te lenen aan overheidsorganisaties en aan andere bedrijven. ${ }^{85}$ Zo werd een groot deel van het personeel uitgeleend aan de in juni 1940 opgerichte Technische Afdeling van TNO, die onder leiding kwam te staàn van de van de BPM afkomstige vezeltechnoloog Jan Uytenbogaart, terwijl het BPM-laboratorium in Amsterdam in een soort 'Wetenschapswinkel' werd veranderd die onderzoek ging doen voor het Nederlandse bedrijfsleven. In 1941 zond het laboratorium een circulaire aan een aantal Nederlandse industrieën, waarin het lab haar diensten aanbood voor onderzoek op fysisch, chemisch en andere gebied. Verschillende bedrijven zijn daarop ingegaan. Het BPM-lab deed - al dan nlet via het 'TNO-loket' - bijvoorbeeld onderzoek naar zeepvervangers voor De klok en andere zeepfabrieken, naar chemische vezels voor de AKU, naar het gebruik van stro voor vezels, naar reukstoffen en naar analysemethoden. Ingenleurs van het BPM-hoofdkantoor in Den Haag bouwden tijdens de oorlog voor de AKU een nieuwe fabriek in de Kleefse Waard bij Arnhem. Op verzoek van het Rijksbureau voor de voedselvoorziening ontwikkelde het BPM-laboratorium, samen met de Chemische Fabriek "Naarden' en de Delftse Gistfabriek, onder leiding van Jan Al een grootschalige synthese van vitamine $C^{\text {G }}$

Dit zijn slecht's enkele voor beelden uit velen. Hoewel de langetermijn effecten van deze oorlogscontacten noott zijn onderzocht, kan men gevoeglijk aannemen dat de researchorganisatie van de BPM zo een breed overzicht kreeg over de technische stand van zaken in het 
Nederlandse bedrijfsleven. Ook kwamen er blijvende contacten uit voort. De research-directeur van het laboratorium in Amsterdam werd na de oorlog bijvoorbeeld commissaris bij Naarden en andere BPM-technici traden soms in dienst bij de bedrijven voor wie ze hadden gewerkt. Een van de meest krasse staaltjes van de invloed van de BPM-researchorganisatie op andere bedrijuen wordt gevormd door de Gist- en Spiritusfabriek in Delft, waar tussen 1957 en 1969 twee als adviseur aangetrokken voormalige directieleden van het Amsterdamse laboratorium, Vermeulen en Rijks, een doorslaggevende invloed hadden op de introductie van nieuwe organisatievormen en budgetteringssystemen. ${ }^{\text {.7 }}$

Voor Philips lag de situatie in de oorlog geheel anders dan voor de BPM. Het Eindhovense bedrijf had niet of nauwelijks last van een grondstoffenprobleem, terwijl de vraag naar electrotechnische producten tijdens de oorlog bleef bestaan, of zelfs groeide. Toekomstplannen en researchprogramma's werden echter door de oorlog lellik doorkruist. Waar het er de BPM vooral om ging am de eigen zittende staf zoveel mogelijk aan het werk te houden, fungeerde het Nat.Lab. als een vluchthaven voor wetenschapsmensen wiens positie elders op de tocht was komen te staan en woor net-gepromoveerden die dreigden in Duitsland te werk te worden gesteld. Toen de Leidse universiteit bijvoorbeeld haar deuren sloot keerde Van Arkel terug naar het Nat.Lab. en bracht daar de oorlogsjaren door. Tussen 1940 en 1943 steeg het personeelsbestand van het Nat.Lab. van 516 naar 633 en de academische staf zelfs van 118 naar 157 (in 1945). Onder hen is een indrukkende lijst wetenschappers die na de oorlog vrijwel onmiddellijk uitzwermden over de Nederlandse industrie en de universiteiten: Theo Overbeek, de opvolger van Kruyt in Utrecht, Cor van Heerden, hoofd van de sector Grondslagenonderzoek van DSM, Bert Staverman, de polymeerchemicus van TNO, Jan Boldingh, researchdirecteur van Unilever, J.M.L. Janssen, hoofd van de research op het gebied van de meet- en regeltechniek bij shell, om enkele van de belangrijkste voorbeelden te noemen. Ervaringen die zij bij Phillips had. den opgedaan verbreidden zich zo naar andere bedrijven. Boldingh en Staverman waren daar heel expliciet over: de wijze waarop het Nat.Lab. werd gerund, stelden zij zich tot voorbeeld toen zl] zelf bil] Unilever in Vlaardingen en bij TNO in Delft laboratoria moesten opzetten.

\section{Organisatie van fundamentele research}

Dat ook zonder Vannewar Bush de wending naar fundamenteel onderzoek binnen de Nederlandse industriële laboratoria zou hebben plaatsgevonden moge inmiddels duidelijk zijn. Vanaf 1945 tot in de jaren 
zestig twijfelde - net als in de Verenigde Staten - geen van de leiders van de grote researchlaboratoria eraan dat er aan fundamentele research

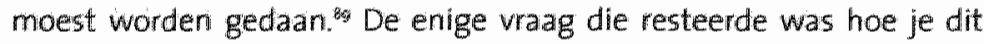
onderzoek zou moeten organiseren. Moest je de basisresearch zoveel mogelijk integreren met het toegepaste onderzoek, het in de woorden van de latere Nat.Lab-directeur Feye Meijer, als het ware laten "uitstulpen' in de meer toegepaste research, zoals in feite onder Holst was gebeurd? Moest je het onderbrengen in aparte 'fundamentele afdelingen' zoals de afdelingen 'Grondslagenonderzoek' bij Staatsmijnen en 'General Research' van het BPM-laboratorium in Amsterdam (in 1949 omgedoopt tot het Koninklijke/Shell Laboratorium, Amsterdam - KSLA)? Of moest je het zelfs onderbrengen in een apart instituut, zoals de AKU had gedaan toen zij het instituut voor Cellulose-Onderzoek oprichtte? Dit waren de vragen waa rover na de oorlog diep werd nagedacht en heftig gediscussieerd ${ }^{\circ}$

Bij Staatsmijnen liepen begin 1948 de gemoederen hoog op toen Henk de Bruijn, een leerling van Kruyt en de chef van de fysisch-chemi. sche afdeling van het Centraal Laboratorium, een krachtig pleidooi hield om de fundamentele research in een apart instituut onder te brengen. Als deelnemer aan een bezoek van Staatsmijnen-technici in juni 1947 aan de fabrieken en laboratoria van IG Farben in Ludwigshafen, welke een van de vele 'spionage-reizen' was die op initiatief van de geallieerden werden georganiseerd, was hij zeer onder de indruk geraakt van de researchorganisatie van de $I G$. Die bestond op dat moment uit een aantal centrale laboratoria voor fundamenteel onderzoek en een groot aantal decentrale divisielaboratoria voor ontwikkelingswerk. Dat model, dat volgens De Bruijn ook bij Philips en TNO was ingevoerd, vond hij ook voor Staatsmijnen gewenst. Deed men dat niet dan dreigde men in de situatie te verzanden van het BPM-laboratorium in Amsterdam waar research en ontwikkeling dwars door elkaar liepen. Pas sinds kort had de BPM volgens hem leergeld betaald en was men begonnen werkelijk fundamenteel onderzoek te organiseren."

Hoewel de toenmalige baas van de research bij Staatsmijnen Gé Berkhoff het elgenlijk met De Bruijn eens was, kreeg de laatste tijdens een discussie over zijn rapport over de reis naar Ludwigshafen wan andere collega's felle tegenstand. Zijn voornaamste opponent was Dick van Krevelen, die op dat moment op de nominatie stond om onder het oppergezag van Berkhoff tot leider van de research op het Centraal Laboratorium te worden benoemd. Van Krevelen vond fundamenteel onderzoek sowieso minder belangrijk dan De Bruijn, maar vooral vond 
hij de vergelijking met de vele malen grotere $I G$ onzinnig. De kwestie sleepte zich maanden voort. Van Krevelen trok uiteindelik aan het langste eind en werd in juli 1948 tot researchlelder benoend.

kijken we naar het verdere verloop van de geschiedenis, dan kunnen we concluderen dat woor Staatsmijnen de aanpak wan Van Krevelen een verstandige was. Dat bleek vooral nadlat hij in de loop van de jaren vifftig een academische ambiance had weten te creêren, net als Holst indertijd bij Philips. Bovendien deed hij wat water bij de wijn en stichtte ook binnen het Centraal Laboratorium (CL) enkele fundamentele afdelingen. Deze werden echter nooit ondergebracht in een apart instituut. Door de relatief geringe omvang van de Chemische Bedrijven van Staatsmijnen (vergeleken met de fabrieken van bijvoorbeeld IG Farben, Shell, Philips, AKU en Unilever) en door de korte afstand - ook letterlijk tussen de fabrieken en het laboratorium was Van Krevelen in de jaren vijftig in staat om net als Holst in de jaren twintig goede contacten te onderhouden tussen het laboratorium en de fabrieken, dit ondanks het feit dat het $\mathrm{CL}$ autonoom zijn budgetten kon vaststellen en mede daardoor de sfeer ademde van een 'luxe paradijsje' voor 'techneuten'.g:

Tegelijkertijd verwijderde het onderzoek bij Philips zich steeds verder van de research praktijk uit de periade-Holst. In zijn onderzoek naar de research bij Philips heeft Marc de Vries laten zien hoe het Nat.Lab. na de oorlog steeds meer ging functioneren als een centraal laboratorium voor fundamenteel onderzoek, ver verwijderd van de problemen van de productie en van de markt. Dit kwam deels door het beleid van Casimir en zijn mededirecteuren, maar gebeurde deels ook sluipend, als een bijproduct van het isolement tijdens de bezettingstijd én van de kort daarna ingevoerde divisiestructuur met eigen divisie-laboratoria. ${ }^{93}$

Die toenemende verwijdering tussen het laboratorium en de fabriek, die bij Philips wellicht het sterkst was, trad ook e ders op. Dit werd deels veroorzaakt door de enorme schaalvergroting die het industrielle onderzoek in de jaren na de oorlog doormaakte. Enkele beschikbare cijfers zijn in tabel 4 bijeen gebracht.94 Daaruit blijkt dat de laboratoria van Shell en Philips op den duur een omvang kregen van zooo medewerkers, of zelfs meer ${ }_{i}$ terwijl de laboratoria van $A K U$, Unilever en Staatsmijnen zo'n 1200 tot 1500 medewerkers telden. Ook de wat kleinere farmaceutische bedrijuen als Gist. Organon (450 researchmedewerkers in 1973) en Duphar ( 367 researchmedewerkers in 1960) bouwden aanzienlijke research-organisaties op. ${ }^{\text {gs }}$ 
Tabel 4: Groe wan het aantal researchmedewerkers van de zes grootste industriele researchlaboratoria, $3950-1970$

\begin{tabular}{|c|c|c|c|c|}
\hline Laboiratortum & 1950 & 1955 & 1960 & 1970 \\
\hline KSLA & 9640 & 1800 & 2173 & 2000 \\
\hline Phillps Nat Lab. & 900 & 1250 & 1600 & 2200 \\
\hline AKU (ind proeffabriek) & 530 & 925 & 1075 & 1500 \\
\hline $\begin{array}{l}\text { Centraal Laboratorium, } \\
\text { Staatsmijnen/DSM }\end{array}$ & 420 & 630 & 780 & 1200 \\
\hline $\begin{array}{l}\text { Unilever kesearch } \\
\text { Zwijndrecht/ } \\
\text { Waardingen en Duiven }\end{array}$ & 50 & 175 & 500 & 1350 \\
\hline $\begin{array}{l}\text { Gist \& Spiritus, Delft, } \\
\text { na } 1967 \text { Cist-Brocades }\end{array}$ & 165 & 290 & 430 & 555 \\
\hline
\end{tabular}

In feite was de groei die optrad nog veel groter dan uit deze cijfers blijkt omdat de grote multinationalle bedrijven in dezelfde jaren ook nog andere grote laboratoria in binnen- en buitenland stichtten. Begin jaren vijftig werkten er in de verschillende laboratoria van Philips ruim 6000 mensen, waarvan ongeveer 1000 op het Nat.Lab. In 1960, toen de Nat.Lab. populatie inmiddels tot 1600 personen was gegroeid, telde het totale personeelsbestand op R\&D-gebied bijna 14.000 mensen. ${ }^{96}$ Voor Shell en Unilever geldt een vergelijkbaar verhaal. Shell stichtte naast laboratoria in het buitenland in de jaren vijttig een apart research-laboratorium op het gebied van plastics in Delft en in de jaren zestig een laboratorium op het gebied van exploratie en productie in Rijswijk. ${ }^{97}$ Dit concept van gespecialiseerde laboratoria was in die jaren ook binnen Unilever populair. Toen in 1955 het resiearchlaboratorium van Unilever in Vlaardingen in gebruik werd genomen was dat laboratorium in eerste instantie vooral bedoeld voor wetenschappelijk onderzoek op het gebied wan eetbare olieèn en vetten. Het Brits-Nederlandse concern had daarnaast in Engeland gespecialiseerde laboratoria opger icht die andere werkterreinen van Unilever bestreken: in Port Sunlight op het gebied 
van wasmiddelen, in Colworth House bij Cambridge op het gebied wan niet-vethoudende levensmiddelen en in Londen op het terrein van toiletartikelen. In de jaren zestig kwam daar in Duiven bij Arnhem nog een tweede Nederlands researchlaboratorium bij. gericht op het onderzoeken van (niet-vethoudende) levensmiddelen. ${ }^{\text {st }}$

\section{De invloed van de industrie op de universiteiten}

Voor al deze laboratoria waren geschoolde mensen nodig, véel geschoolde mensen ${ }^{99}$ Liefst op gebieden waar de industrie wat aan had. Maar die mensen waren er niet. Vooral vlak ma de Tweede Wereldoorlog was de personeelvoorziening voor de industriêle researchlaboratoria een gigantisch probleem. Om de eerste nood te lenigen deed de industrie er alles aan om goede chemici en fysici zo snel mogelijk aan zich te binden. Bijvoorbeeld - zoals bij de BPM - door hen direct na het afstuderen een arbeidscontract aan te bieden en hen dan, op kosten van het bedriff aan een promotie-onderzoek te laten werken aan een Nederlandse of buitenlandse universiteit: ${ }^{100}$ Op langere termijn bood dit echter geen soulaas. Daarvoor was een structurele uitbreiding van het hoger onderwijs geboden. De BPM tastte diep in de buidel en schonk in 1946 - ten volle waarderend de grote betekenis van Nederlandse geleerden en ingenieurs voor de ontwikkelling van de industrie, en doordrongen van het feit dat de snelle groei van wetenschap en techniek het noodzakelijk maakt belangrijke vernieuwingen aan te brengen aan verschillende instellingen wan Hoger Onderwijs" " het toen gigantische bedrag van drie miljoen gulden aan de Nederlandse staat, besternd voor de bouw van een proeffabriek voor Fysische Technologie en een proeffabriek voor Chemische Technologie vari de Technische Hogeschool Delft en woor de modernisering van het Natuurkundig Laboratorium in Leiden. ${ }^{101}$

Aan deze schenking had de BPM, afgezien van de oormerking voor de drie genoemde laboratoria, weinig voorwaarden verbonden, maar het bedriff verwachtte wel dat de bijzondere leerstoel fysische techriologie in Delft, die door het toenmalige technische genie van het olieconcern, Van Dijck, werd bekleed, omgezet zou worden in een gewone leerstoel waarop een nieuwe kracht zou worden benoemd. Dit geschiedde. Op de leerstoel werd, toeval of niet, een jonge natuurkundige van het BPMlaboratorium in Amsterdam benoemd: Hans Kramers. Als er ooit sprake was van een kredietbenoeming, dan toen wel, want Kramer's was niet gepromoveerd en had bij zijn benoeming in 1947 slecht één publicatie op zijn naam staan. Hij maakte de gestelde verwachitingen echter ruim- 
schoots waar en stichtte een school op het gebied van de fysische technologie in Delft van wereldnaam, die tientallen ingenieurs afleverde die opklommen tot leidinggevende posities in de industriële research en aan de universiteiten. In 1963 verliet Kramers de TH en werd na een intermezzo van enkele jaren bij Euratom, researchdirecteur bij Akzo. ${ }^{\text {1as }}$

Het voorbeeld wan de BPM-schenking illustreert fraai de eerder gesignaleerde omdraaling van de krachtsverhoudingen tussen industrie en universiteit na de Tweede Wereldoorlog. Vóór de oorlog liep de kennisstroom voornamelijk van de universiteit naar de industrie en was de invloed van de industrie in het hoger onderwijs betrekkelijk gering. kijken we bijwoorbeeld naar de samenstelling van het college van Curatoren van de TH in Delft dan blijkt dat dit College vóór de oorlog wrijwel uitsluitend bestond uit figuren met een duidelijk politieke achtergrond, of lieden uit de waterstaat. Met uitzondering van de plaatselijke industrieel Waller, directeur van de Gistfabriek, lijken de paar verdwaalde industriëlen in het College, zoals Regout en Colijn, eerder vanwege hun politieke affiliaties tot Curator te zijn benoemd. Na de oorlog verandert het beeld volledig. De research-leiders van Philip, Holst en Casimir namen nu zitting, naast, bijvoorbeeld, Wijffels van Staatsmijnen, Van Doormaal van Ketjen en Schepers van Shell. Analoog aan de studies die er bestaan over ministers, kamerleden en hoogleraren, zou een grondige prosopografische studie van de samenstelling van en verschuivingen in de Colleges van Curatoren van de Nederlandse universiteiten, zoals. Pieter Caljë ook reeds suggereerde, zeker een desideratum zijn. Er zijn aanwijzingen dat de ontwikkelingen die ik zojuist met betrekking tot Delft signaleerde zich ook elders voordeden. ${ }^{103}$ Nat.Lab.directeur Verwey was bijwoorbeeld curator in Utrecht en Duphar-directeur Reerink in Leiden. Ook binnen TNO en ZWO ontbraken invloedrijke industriële researchleiders niet. Verwey was van 1966 tot 1971 voorzitter van SON, de Stichting Scheikundig Onderzoek in Nederland die de tweede geldstroom op het gebied van de chemie beheerde. Hij wist verschillende andere industriele onderzoekers te benoemen in het SON-bestuur en in de besturen van de werkgemeenschappen. ${ }^{104}$

Lidmaatschap van een College van Curatoren was éen manier om invloed uit te oefenen, of althans een vinger aan de pols te houden, zeker wat betreft het benoemingen-beleid, een andere manier was de deelname aan een van de vele regeringscommissies die in de jaren veertig en vijftig werden ingesteld om het hoger onderwijs te reorganiseren. Met name Holst nam zitting in verschillende belangrijke commissies en spande zich bijzonder in woor de oprichting van een tweede Technische 
Hogeschool ${ }^{\text {ros }}$ Deze ging in 1956, niet geheel toevallig, in Eindhoven van start. Ondanks dit voor de industrie belangrijke initiatief groeide het hoger onderwijs naar de zin van het multinationale bedrififsleven nog weel te langzaam. De doorbraak kwam eind 1957 toen de Minister van Onderwijs de Commissie Ontwikkeling Natururetenschappelijk Onderzoek installeerde onder voorzitterschap van Nat.Lab-directeur Henk Casimir. Naast vier hoogleraren uit Leiden, Utrecht en Croningen. maakte ook de research-directeur van Shell, Willem Slotboom, deel uit van deze invloedrijke commissie. Toen een jaar later het eindrapport verscheen, logen de aanbevelingen er niet om. "Het bouwtempo ten behoewe van het onderzoek moet circa tienmaal worden versneld", stelde de commissie en 'het aantal hoogleraren moet in korte tijd met een factor drie worden opgevoerd. Anders dan meestal het geval is verdween het eindrapport van de commissie.Casimir niet in de spreekwoordelijk la. In de tien jaar die volgden, werden de aanbevellingen van de commissie vrijwel onverkort uitgevoerd. Het budget voor het universitaire onderwijs en onderzoek steeg van $\mathrm{fl} .185$ miljoen in 1958 , via $\mathrm{fl} .723$ miljoen in 1964 , naar fl. 2.242 miljoen in 1970.05

In de jaren zestig groeide dientengevolge het aantal hoogleraren explosief. Op het gebied van de natuur" en scheilkunde werd een zeer groot deel van de nieuw geschapen leerstoelen door mensen uit de industrie bemand. Enkelen zetten de stap naar de universiteit ook omdat het klimaat in de industrie met betrekking tot het fundamentele onderzoek veranderde. Er ging een andere wind wasien: onderzoek diende zich meer te richten op de markt. ${ }^{107}$

\section{De tucht van de markt}

Tussen ongeveer 1966 en 1974 veranderden de researchorganisaties van vrijwel alle grote ondernemingen ingrijpend, zowel wat betreft de oriëntatie van de researcin als wat betreft de structuur van de organisatie. Fundamenteel wetenschappelijk onderzoek werd afgebouwd, onderzoek dat het korte termijn belang diende groeide. Om de eisen van de markt en de mogelijkheden van de research beter op elkaar af te sternmen voerden veel bedrijven de zogeheten matrix-organisatie in. Een van de kenmerken was het werken met programma's of projecten, die gedlefinieerd werden vanuit de behoeften van de markt. ${ }^{\text {rob Naast }}$ deze veranderingem, die op zich reeds heel ingrijpend waren stagneerde ook de groei van de laboratoria. Terwijl 'speurwerk' in 1965 op een congres van de Nederlandsche Niatschappij voor Nijverheid en Handel nog juichend de 'sleutel voor de toekomst' was genoemd, keerde het tij zeer 
kort daarna: ${ }^{\text {ivg }}$ twintig jaar onafgebroken groel trad stagnatie in, of zelfs inkrimping. Dit proces was niet uniek voor Nederland; het voltrok zich ook in andere hoog-geindustrialiseerde landen. Bij Shell zwakte het groeitempo reeds omstreeks 1960 af. Philips volgde ongeveer 1965 , de andere grote bedrijuen na 1967 . Het meest dramatisch waren de veranderingen bij $A k z O$, dat net in 1969 was ontstaan als resultaat van een fusie tussen de AKU en de Koninklijk Zout-Organon. Werkten er in 1970 nog meer dan 1500 mensen op researchlaboratoria in Arnhem, in 1980 was dat cijfer tot onder de goo gedaald :

Het is een opvallend gegeven dat het hier kort geschetste herstructureringsproces zich over de gehele linie voltrok. Vooral als we bedenken dat de hier besproken bedrijuen veelal op geheel verschillende markten opereerden. Een deel van de oplossing van dat "raadsel der gelijktijdigheid en gelijksoortigheid' kan gevonden worden in het feit dat een aantal economische factoren over de gehele linie werkzaam was. ${ }^{\text {"z }}$ In de eerste plaats de loonkosten die sinds begin jaren zestig, toen aan de geleide loonpolitiek in Nederland een einde kwam; explosief stegen. Deze factor drukte vooral zwaar op researchorganisaties, waar immers de lonen en salarissen een zeer belangrijk deel van de kosten uitmaken. " ${ }^{\prime \prime}$. n de tweede plaats de steeds scherpere concurrentie op alle fronten. Sinds de vorming van de $E E G$, eind jaren vijfig, nam de concurrentie in Europa binnen alle bedrijfstakken sterk toe, temeer daar Amerikaanse bedrijven zich steeds vaker op de Europese markt begaven, daarmee de spoeling voor andere bedrijven dunner makend. In de derde plaats trad op vele belangrijke markten, bijvoorbeeld op de markt voor kunststoffen, marktverzadiging op. De inhaalvraag van na de Tweede Wereldoorlog was vervuld. Vele gezinnen hadden na de eerste loonstijgingen begin jaren zestig de belangrijkste luxe-goederen, zoals auto's en televisies, aangeschaft. Om ze nog meer te laten consumeren dienden extra marketinginspanningen te worden geleverd. ${ }^{\text {"* }}$

Al deze factoren tezamen kunnen tot op grote hoogte verklaren waarom de research eind jaren zestig onder druk kwam te staan. De marges namen af, het kostenbewustzijn nam toe. Dit maakt het begrijpelijk dat de researchinspanning eens kritisch onder de loep werd genomen. Om te begrijpen waarom de bedrijven in veel gevallen ook zulke vergelijkbare oplossingen kozen lijkt de economische analyse echter ontoereikend. Pas wanneer ook sociale en culturele factoren in de beschouwing worden betrokken, lukt het ook dat aspect van de geschetste ontwikkeling te begrijpen.

$\| k$ val weer terug op het beeld van de geblinddoekte polonaise. Sinds 
het begin van de jaren vijftig stonden de researchleiders van alle grote Nederlandse bedrijuen zeer nauw met elkaar in contact. In de loop wan 1954 had de directeur van de Nijverheidsorganisatie TNO, Daniel Dresden, namelijk het intitatief genomen om de researchleiders van Shell, Philips, AKU, Unilever en Staatsmijnen bij elkaar te roepen om onderling te overleggen over zaken als de organisatie van research, budgetteringssystemen, en over alles wat verder ter sprake kwam. Dat initiatief vond weerklank, want sinds dat jaar kwam deze informele "Contactcommissie Nijverheidsorganisatie" - in de wandeling de 'Researchclub' genoemd - bestaande uit de leiders van de vijf grootste industriële laboratoria en de directeur van de Nijverheidorganisatie TNO, gedurende decennia, mogelijk tot op de dag van vandaag, bij elkaar. Men mag vermoeden dat er binnen dit gremium ook overlegd is over de zojuist geschetste problemen van het hoger onderwijs en over de strategieën een en ander op te lossen. De moeilijkheden die de research in de jaren zestig ondervond en de mogelijkheden die matrixorganisaties boden zullen ongetwijfeid ook aan de orde zijn geweest."

Vanaf 1965 werd het terrein van wederzijdse beinvloeding verder werbreed. In februari van dat jaar organiseerde de OECD, de transatlantische organisatie voor economische samenwerking en ontwikkeling die uit de Marshall-hulp was voortgekomen, een conferentie over 'Research Policy and Company Policy' in Monte Carlo, waaraan naast enkele Amerikanen de researchdirecteuren van de belangrijkste Europese ondermemingen deelnamen. Op deze conferentie, die door Casimir als key-note speaker geopend werd, nam men thet initiatief tot de oprichting van de European industrial Research Management Association. Deze organisatie, die in 1966 definitief tot stand $\mathrm{kwam}$, is sinds die tijd een belangrijk platform waarop de polonaise van beleidsideeèn en managementconcepten kan plaatsvinden. Talloze rapporten en aanbevelingen over zaken als octrooien. licenties, personeelkosten en budgetteringssystemen $z i j n$ sindsdien gepubliceerd." ${ }^{\text {th }}$

Het was binnen dit soort circuits dat het meer dan twintig jaar gekoesterde geloof in de vruchtbaarheid van fundamentele research begon te tanen. Hoewel het zogenaamde "lineaire model', toegeschre. ven aan Vannevar Bush, dat uitging van een onproblematische opeenvolging van basis research-applied research en development, in zijn simpele vorm binnen de industrie nooit aanhangers heeft gehad - ja zelfs, volgens David Edgerton, wellicht alleen een 'stropop' was die figureerde in de geschriften van critici als Nathan Rosenberg. Wiebe Bijker en Trevor Pinch - waren de verwachtingen ten aanzien van het fundamentele 
onderzoek bij velen wel hoog gespannen." Het toenemende kostenbewustzijn van de jaren zestig zette echter de wraag naar de effectiviteit en de efficiency van fundamenteel onderzoek op de agenda. Moeilijke inschattingen moestern gemaakt worden om te beslissen of de uitkomsten van fundamenteel onderzoek überhaupt te gering waren, of dat er sprake was van een 'verminderde meeropbrengst'. Casimin begon zich vanaf 1962 zorgen te maken over het rendement van de fundamentele research. Gedachten over het uitgeputte potentieel van wetenschappelijk doorbraken speeilde daarbij een rol. Was de bloei van de industriéle technologie in de achterliggende decennia niet op ontdekkingen als het atoommodel van Bohr en de quantummechanica gebaseerd en dreigde het toepassingspotentieel daarvan niet uitgeput te raken? Was het wachten niet op cruciale wetenschappelijke doorbraken, die een nieuwe groeigolf mogelijk zouden maken? Lagen de belangrijkste mogelijkheden wellicht op het terrein vain de biochemie en de moleculaire biologie? En zo ja moest Philips daar dan wat aan gaan doen? Dit soort gedlachten plaagden de researchleiders. ${ }^{.8}$

Een belangrijke, veel aangehaalde studie op dit terrein werd vanaf 1963 in opdracht van het Pentagon verricht. In Amerika was defensie cle grootste financier van zogeheten basic research. Toen ook daar de researchkosten , die alleen al voor de basic research zo'n 100 miljoen dollar per jaar bedroegen, sterk begonnen op te lopen, was het zaak het hele beleid eens kritisch door te lichten. Het zogeheten Project Hindsight werd gestart, waarin verschillende onderzoeksteam de opdracht kregen de geschiedenis van een groot aantal wapensystemen te reconstrueren en te bezien welke rol fundamenteel onderzoek daarbij had gespeeld. De conclusies van de vanaf 1966 verschijnende deelrapporten en het in 1969 verschenen eindrapport lieten weinig heel van de gedachte dat investeren in fundamentele research een lonende optie was. Nog geen half procent van alle innovaties kon daadwerkelijk op het conto van ongericht wetenschappelijke basisonderzoek worden geschreven,

Dat deze gevolgtrekking, die door de onderzoekers van het Pentagon luid werd verkondigd, veel opzien baarde en druk werd bediscussieerd in het Amerikaanse congres is niet verwonderlijk. Ondanks de vele methodologische tekortkomingen van het onderzoek, onstond er toch een algehele stemming tegen het doen van fundamenteel onderzoek, zowel in nationale gremia op het gebled van wetenschapsbeleid, als in kringen van de industrie. Dat daarbij geen recht werd gedlaan aan de belangrijke kritiek die op het Hindsight-rapport werd geleverd, onderstreept mijn 
stelling dat koerswijzigingen in researchbeleid vaak het karakter hebben van speuren op de tast en geen uitkomst zijn van een louter rationeel proces. ${ }^{200}$

Als gevolg van deze omslag in het denken ontstond er rond 1970 een nieuw vocabulaire. Het was de tijd van de drie M's: markt, matrix en McKinsey:a Ook die laatste $M$. Want als er éen groep van bedrijwen garen heeft gesponnen bij de krisis in de industriële research van de jaren zestig dan zijn het well de organisatie-adviesbureaus. Bij alle bedrijven waren de Boston Consultants, de McKinsey's, de Knight-Wegensteins en de Urwick's kind aan huis om de introductie van strategische beleidscycli en matrixorganisaties te begeleiden. ${ }^{\text {ia }}$

Begrippen als fundamentele en toegepaste research, die teveel vanuit het onderzoeksproces zelf gedacht waren, raakten uit. Nieuwe begrippen, die met de verschillende tijdschalen van de planningscycli verbonden konden worden, kwamen in de modevoortaan diende er over exploratieve research voor de lange termijn, vernieuwende research voor de middenlange termijn en ondersteunende research voor de korte termijn gesproken te worden. Akzo voerde deze categorieën omstreeks $1970 \mathrm{in}$. Bij Shell werd de term exploratieve research al langer gehanteerd. Daarnaast verschoof in de jaren zestig en zeventig de aandacht geleidelijk van 'R\&D' naar het bredere begrip 'innovatie.' ${ }^{23}$

Achter deze wisseling wan vocabulair gingen zeer pijnlijke beslissin gen en ingrepen schuil. De personeelreductie bij Akzo is al genoemd. Shell en Unilever, op hum beurt, kwamen terug op hun nog niet zo lang daarvoor ingezette beleid om de research op bepaalde terreinen onder te brengen in gespecialiseerde laboratoria. De grote laboratoria kwamen weer in de mode. Shell bezuinigde vanaf 1972 fors, sloot het Plastics Laboratorium in Delft en concentreerde het onderzoek in Amsterdam. ${ }^{124}$ Unilever sloot het pas opgerichte laboratorium in Duiven en bundelde de research in Vlaardingen. ${ }^{25}$ Bij Philips was de situatie evenmin florissant. Hoewel in principe reeds omstreeks 1970 was besloten om de greep van de productdivisies op de research te vergroten, kwam er geen helder systeem van aansturing tot stand. Het bedrijf kon maar moeilijk afstand nemen van de voorheen zo succesvolle oriëntatie op fundamentele research en modderde in zekere zin door tot begin jaren negentig, toen knopen werden doorgehakt. ${ }^{36}$

\section{Van nationale maar internationale kennisnetwerken}

Begin jaren tachtig keerde het tij. Ik zal echter kort zijn over deze periode. Het beeld is verwarrend. Diepgaand onderzoek naar die periode 
heb ik nog niet gedaan. Ik presenteer enkele voorlopige observaties die lk belangrijk acht.

In de eerste plaats de constatering dat in deze periode de verschillen tussen de grote multinationals toenamen. Maakten de grote bedrijven gedurende de drie eerste perioden min of meer dezelfde ontwikkelingen door, na 1980 werd dit steeds minder het geval. Hoewel in het algemeen aan de neerwaartse trend in de industriele $R \& D$-investeringen omstreeks 1980 een einde kwam, en er een nleuwe periode aanbrak met hooggespannen verwachtingen ter aanzien van de research, gingen er achter deze algemene trend grote verschillen tussen bedrijuen en bedrijfstakken schuil. ${ }^{12}$ Zo werd het Shell-laboratorium in Amsterdam reeds vanaf het begin van de jaren tachtig geleidelijk ingekrompen, gedurende de laatste vier jaar zelfs zeer fors. De chemische research is bij Shell grotendeels weggesaneerd en de niet met de divisies is verbonden corporate research is opgeheven. Daar tegenover staat dat bedrijven als DSM en Philips de afgelopen decennia soms duidelijke perioden hebben gekend waarin er weer zeer fors in de research werd geinvesteerd.

Deze verschillen hangen ongetwijfeld samen met het verdwijnen van breed geschakeerde ondernemingen. Bedrijven kozen voor een beperkte set kernactiviteiten. Grote, geïntegreerde concerns op het gebied van de olieproductie, de chemie en de farmacie hebben zich de laatste vijftien jaar opgesplitst in apart oliemaatschappijen, chemische bedrijven en farmaceutische ondernemingen: ${ }^{\text {so }}$

Een tweede belangrijk kenmerk is de sterk gegroeide samenwerking tussen de universiteiten en de industrie." Werd het universiteitssysteem door Casimir en de zijnen in 1958 ontworpen voor een samenleving van woortdurende groei, waarin the sky the limit was, na de stagna. tie van het industriële onderzoek rond 1970 werd de potentiële capaciteit van het universiteitssysteem in de bèta-wetenschappen in feite een waterhoofd dat niet meer in verhouding stond tot de indur-. triële vraag. Om de gevolgen van dalende studentenaantallen en daarmee samenhangende afnemende financièn te keren, zijn hoogleraren in de bèta-vakken kleine ondernemers geworden die hun onderzoeksfinanciering moeten zlen te krijgen van de industrie. ${ }^{13}$ De industrie op haar beurt wil maar wat graag samenwerken, omdat de afname van het interne fundamentele onderzoek de noodzalk vergroot om goed op de hoogte te zijn van fundamenteel-gerichte universitaire research. Daarbij heeft zich een duidelijke internationalisering voorgedaan. Ging het in de jaren tachtig nog vooral om contacten met de Nederlandse 
universiteiten, tegenwoordig 'shoppen' bedrijven over de gehele wereld om de beste krachten op een bepaald terrein aan zich te binden. Een bedriff als DSM laat twee seniorwetenschappers full time rond de wereld reizen om te netwerken met ongeveer 2000 onderzoekers. Eén doet China en Rusland, waar de wetenschappers goed en goedkoop zijn. De ander bestrijkt de rest van de wereld Daarnaast heeft de universitair-industriële samenwerking binnen Nederland een andere gedaante gekregen door de oprichting van vier Technologische Top-Instituten (TTIS) op het gebied van de metalen (NIMR), polymeren (DPI), voeding, en telematica. In deze TTI's participeren meerdere bedrijven, samen met NWO en de universiteiten. ${ }^{35}$ Het aantal personeelsplaatsen dat door SON/STW gefinancierd werd voor toepassingsgericht chemisch onderzoek steeg van 63 in 1985 naar 170 in 1997 , terwijl het personeelsbudget voor het meer zuiver-wetenschappelijke onderzoek in dezelfde periode licht daalde. ${ }^{\text {36 }}$

Mijn derde constatering heeft betrekking op de grote veranderingen die zich de laatste tien jaar hebben voltrokken. ${ }^{\text {'3 }}$ Vanaf het moment dat de eerste betrouwbare cijfers beschikbaar zijn (eind jaren vijftig) tot 1990 namen de 'Grote Vijf' steevast zo'n 65 procent van de researchuitgaven in de particuliere sector voor hun rekening. Un 1999 was dit aandeel echter plots gedaald tot 53 procent en gezien de ontwikkelingen van de laatste jaren ligt dit percentage nu ongetwijfeld nog lager. Nieuwe bedrijwen, die lange tijd nauwelijks een rol speelden in het Nederlandse researchlandschap, duiken nu op aan de top: ASML, in 1991 afgesplitst van Philips, waar 1500 mensen in onderzoek en ontwikkeling werken; Océ met 1075 onderzoekers en ontwikkelaars; twee buitenlandse bedrijuen, Lucent en Ericsson, met elk zo'n 1100 tot 1200 mensen in onderzoek en ontwikkeling. ${ }^{18}$ De R\&D-activiteit van bedrijven op het gebied van de electronica en de informatica groeide blijkbaar veel sterker dan die van bedrijven op het terrein van de chemie.

Een vierde en laatste observatie is dat het fundamentele onderzoek, dat sinds ongeveer 1970 in sterk afgeslankte vorm bij de meeste bedrij. ven nog steeds bestond, de laatste paar jaar vrijwel geheel van de kaart is verdwenen. Bij DSM vond een forse reductie van het los wan de divisies staande onderzoek plaats, terwijl deze zogeheten corporate research bij Akzo Nobel (in 1999) en Shell zelfs geheel werd stopgezet. ${ }^{\text {'al }}$ volgens de plannen moet het centrale laboratorium van Akzo Nobel in Arnhem, dat tussen 1980 en 1995 weer geleidelijk gegroeid was tot zo'n 1300-1400 werknemers, door reorganisaties uiteindelijk worden ingekrompen tot een bezetting van 200 man, die alléén voor opdrachten van 
divisies mogen werken. Noor van Andel, de met de VUT-gestuurde leider van de corporate research van het bedrijf schetst deze ontwikkelingen als volgt: 'De mackt is aan het verschuiven van directie naar grootaandeelhouders. Lange-termijnresearch, de visionair-wetenschappelijke cultuur die niet het ontwikkelen van producten voorop stelt maar de kennis om dat over 5 jaar te doen, is daarvan de dupe. Die is helemaal verdwenen, niet alleen bij Akzo, ook elders." ${ }^{4 z}$

Tegen deze achtergrond is het haast aandoenlijk om te zien hoe de 'Staf Director Technology' wan Akzo Nobel (Jan de Wit) in zooi probeerde binnen 'chemisch Nederland' een discussie aan te zwengelen ower de vraag of de tweede geldstroomorganisatie op het gebied van de chemie niet in handen van de industrie moest worden gegeven. Derde geldstroom-contracten waren vaak op een te korte termijn gericht, terwijl de industrie ook behoefte had aan fundamenteel onderzoek, gericht op de lange termijn: of de universiteiten die inspanning maar even wilden leveren. De discussle die hierover in het Chemischa Weekblad losbarstte was soms behoorlijk geagiteerd. Erg overtuigend vonden sommigen het iniatief uit de Akzo-hoek niet, zo kort nadat men zelf het fundamentele onderzoek de nek om had gedraaid ${ }^{143}$

of dit industriële beleid verstandig is, kan ik in zijn volle omvang moeillijk beoordelen. Enerzijds is mijn conclusie op basis van het hier gepresenteerde historische verhaal dat bedrijven die kennis van buiten willen assimileren, zoals nu in de mode is, er goed aan doen een hoog. niveau van kennis en kunde in eigen huis te onderhouden. Het doen van fundamenteel onderzoek op gebieden die cruciaal zijn voor het bedrijf kan daarbij van groot belang zijn. Waarschijnlijk is dit een van de moeilijkhedlen waar het middlen- en kleinbedrijf mee kampt op het gebied van de research. Hun eigen onderzoeksinspanning heeft doorgaans te weinig "kritische massa" om resultaten die elders in de wereld worden geboekt te signaleren en te assimileren. Grote bedrijven die hun fundamentele onderzoek stopzetten spelen, zo bezien, gevaarlijk spel. Piet Lemstra, hooglerala polymeerchemie in Eindhoven, spreekt in dit verband zelfs over 'een irreversibel proces met grote gevolgen voor de kennisinfrastructuur in Nederland en de samenwerking tussen universiteiten en industrie. fasenleer laat fraai zien hoe sterke kennisposities op academisch gebied doorgewerkt hebben in het Nederlandse bedrijfsleven, maar alleén doordat de bedrijven zelf het betreffende onderzoeksterrein met kracht ter hand namen. Het laat bovendien zien dat de bedrijven soms decennia lang hun kenniswoorsprong in bepaalde richtingen verder hebben 
weten uit de bouwen. Tegenover het mogelijke nadeel van een door 'padafhankelij:k' te geringe flexibiteit, staat het mogelijke voordeel van een vergrote concurrentiekracht op het terrein waarop men een voorsprong heeft. In het geval van ureum heeft DSM dit voordeel jarenlang kunnen uitbuiten. Dit veronderstelt echter wel dat men het betreffende kennisdomein actief blijft bewerken. De beleidswijzigingen die sinds 1970 in het industriële onderzoek hebben plaatsgevonden roepen de vraag op of sommige bedrijven dit gegeven nog wel voldoende onderkennen. Industriële kennisposities die gedurende decennia werden opgebouwd, lijken de laatste jaren in hoog tempo te worden afgebroken. Steunen op universitaire kennis zonder een intensieve eigen activiteit, biedt geen soelaas.

Anderzijds is een eenmaal ingezette trend moeilijk te keren. De concurrenten bezuinigen tegenwoordig ook op de research, waardoor hun kostenpositie verbetert, en de aandeelhouders eisen hoge winstern op korte termijn, zodat men als gevolg van beide invloeden wel moet vollgen. Bovendien hebben bedrijven in dezelfde branche - al dan niet ingefluisterd door dezelfde 'voorspellers' - vaak overeenkomstige toekomstverwachtingen ${ }^{\text {as }}$ De geblinddoekte polonaise gaat zo onverminderd voort. 


\section{Dankwoord}

Mijnheer de rector, leden van het bestuur van de Stichting Historie der Techniek, geachte aanwezigen!

Ik kom tot een afronding. De afgelopen veertig minuten heb $\mathrm{k}$ u door vier fasen in het Nederlandse industriele onderzoek gevoerd, waarvan ik er twee uitvoerig behandeld heb. Om het beeld met betrekking tot de laatste twee fasen scherper te krijgen is nog veel onderzoek nodig. Dat zal de komende jaren zeker een van mijn aandachtspunten zijn.

Naast de verdeling in vier fasen heb ik twee andere aandachtspunten op mijn agenda gezet: de interactie tussen bedrijven onderling en tussen bedrijven en het hoger onderwijs, en het deels daarmee samenhangende modieuze, collectief tastende karakter van beleidswijzigingen.

Wat betreft het eerste punt meen $k$ overtuigend te hebben aangetoond hoe belangrijk de interactie tussen de grote bedrijven in Nederland de laatste eeuw geweest is en hoe ingrijpend hun invloed op het hoger onderwijs veranderd is.

Met betrekking tot het tweede punt hoop ik u ervan overtuigd te hebben dat zelfs grote bedrijwen voor een deel speuren op de tast. Vraagstukken van researchbeleid, waaronder inschattingen met betrekking tot toekomstige ontwikkelingen zijn complex. Pasklare antwoorden zijn niet aanwezig. Dit levert een breed speelterrein op voor de Arthur $D$. Little's en de McKinsey's om tegen veel geld hun ideeën aan de man te brengen.

U zult hebben bemerkt dat ik een grote voorkeur heb woor empirisch historisch onderzoek $k_{i}$ walrbij daden en gedachten van mensen van vlees en bloed zichtbaar worden gemaakt. Het is mijn stellige overtuiging dat in onze maatschappij historisch onderzoek de belangrijke culturele taak heeft de openbare mening te informeren over kwesties die ons alleen aangaan. De geschiedenis van het industriële onderzoek en van de verhouding tussen industrie en universiteit is daarbij een belangrijk thema. De invloed hiervan op de ontwikkeling van onze samenleving is groot.

Ik hoop de komende jaren op deze wijze voort te gaan. Mijn nieuwe staat geeft me daarbij extra armslag. I dank het Bestuur van de Stichting Historie der Techniek zeer voor het genomen besluit de techniekgeschiedenis in Nederland te bevorderden door het instellen van 
een leerstoel in Maastricht. De aan mij gestelde werwachtingen hoop ik de komende jaren te kunnen waarmaken. Het College van Bestuur en het Bestuur van de Faculteit der Cultuurwetenschappen dank ik zeer voor het gestelde vertrouwen door mij te benoemen als hoogleraar Geschiedenis van Wetenschap en Techniek, en hun onderlinge samenhang.

Velen zijn mijn reisgenoten geweest op de tocht die uiteindelijk tot deze benoeming heeft geleid. $U$ zult mij niet euvel duiden, hoop ik, dat ik als chronologie-freak, mijn reisgenoten in chronologische volgorde voor hun gezelschap bedank:

- in de eerste plaats mijn ouders, die mij steeds van nabij gevolgd en gesteund hebben en die indertijd, toen ik nog 'thuis' woonde, zoals dat heet, een sfeer schiepen waarin over talloze onderwerpen kon worden gepraat, zodat nieuwsgierigheid maximaal tot ontplooing kon komen;

- in de tweede plaats Marijke, die mij al meer dan 25 jaar op al mijn kronkelwegen volgt, zowel door het hele land, als in intellectuele zin. Lieve Marijke, je bent me steeds tot grote steun geweest, en daarvoor wil ik je vanaf deze plaatst heel erg bedanken.

Verder:

- Freek Kaptein, die mij de beslissende zet gaf om mijn politieke, filosofische en historische zijwegen tijdelijk af te breken voor het afronden van mijn scheikundestudie;

- Wim Hornix, die als initiator en inspirator van het kleurstofproject mij definitief op het spoor zette van de wetenschaps-en techniekgeschiedenis; die mij de waarde van close reading van historische bronnen leerde, en die mij op liberale wijze ongebreideld liet grasduinen in zijn fantastische bibliotheek;

- Henk van den Belt, mijn kamergenoot tijdens de eerste jaren van het kleurstofproject die mij gedurende twee jaar een crash course in de sociologie en de economie heeft gegeven, en zo de lessen die Rob Kayzel mij indertijd in een Amsterdamse mensa gaf aanmerkelijk heeft verdiept;

- Arie Rip, die als lid van de begeleidingscommissie van het kleurstofproject altijd zoveel nieuwe perspectieven heeft geopend, zo kritisch kon zijn en tevens zoveel intellectueel spannende zaken op de agenda zette, dat hij zeker tot een soort alter ego is geworden. De regelmatig bij mij opkomende vraag "Wat zou Arie hiervan vinden?" bewijst het. 
- Wiebe Bijker, die ruim twintig jaar gelleden met Trevar Pinch de Nijmeegse kleurstofgroep bezocht en die sindsdien techniekgeschiedenis en theorievorming zo elegant en transparant met elkaar verbonden heeft, dat hij mij blijvend heeft weten te inspireren. Zijn invloed op de Nederlandse techniekgeschiedenis is vele malen groter dan hij vermoedelijk zelf beseft;

- Paul Klep, die, behalve dat hij mijn promotor heeft willen zijn, een enorme invloed op mijn vorming gehad heeft door het fantastische maandelijkse colloquium over sociale en economische geschiedenis dat hij in Nijmegen organiseerde. De papers die we daar bespraken en de discussies die we daar hebben gevoerd, hebben mij pas van chemicus tot historicus gemaakt;

- Johan Schot, die bijna twintig jaar geleden als student mijn kamer in Nijmegen binnen viel om een gesprek te beginnen over meekrap. Een gesprek dat sinsdien niet meer is gestopt en waaruit behalve gemeenschappelijk historisch werk ook een vriendschap is gegroeid waarvoor ik hem heel dankbaar ben;

- Harry Lintsen, die techniekhistorisch Nederland onschatbare diensten heeft bewezen door met verbeelding, durf, vasthoudendheid en inzet een groot project over de geschiedenis van de techniek in Nederland te starten dat nu al 14 jaar loopt. Dit inmiddels ook door Johan Schot en Arie Rip geleide project heeft een niet te becijferen invoed gehad op de ontwikkeling van mijn vak in Nederland;

- mijn chemiehistorische companen Peter Morris, Tony Travis, Christoph Meinel, Carsten Reinhardt en Bill Brock die mij op gezette tijden ontvoerden naar het veld van de internationale chemiegeschiedenis, weg van de geschiedenis van de Nederlandse techniek;

- en last but not least, de collega's en studenten van de Faculteit Cultuurwetenschappen in Maastricht die mij al meer dan tien jaar iedere dag ervan overtuigen dat Maastricht in Nederland absoluut de beste plaats voor de wetenschaps- en techniekgeschiedenis is.

\section{Ik dank u voor uw aandacht|}




\section{Noten}

1 Een analyse van denkpatronen van die luide verkondigers is te vinden im; Rein de Wilde, De kenniscultus. Over nieuwe wormen van woorutgangsgeloof, inaugurele rede Universiteit Maastricht, 22 juni 2001 (Mastricht 200 ).

2 Woorkom dat studenten naar WS gaan', Dagblad de Limburger (2 sept. 2003). Bi. Wammes Bos, 'Universiteiten moeten dichter tegen bedrifisteven a anschurken", Observant (4 sept. 2003), 4 Zie ook: Ian Rotmans, "De innowatieve universiteit tussen droom en daad', Observant (11 sept. 2003). 5. Wammes Bos, "Turbo-Jo rasst door de uniwersitest", Observant (25 sept. 2003). 7

3 Vgl. Paul Wouters, "De aktiviteiten van de chemie en industriegroep" in: Bulletin. Kommunikatiemedium aan de subfaculteit der Scheikunde wan de Vrije Universiteit 3 (2) (oktober 1970), "De positie van de onderzoeker in het bedrijf, Bulletin Scheikunde 4. (3) (mei 1972), 25-26.

4 zo was er plots felle kritiek op het zogeheten scouten, de praktijk dat hoogleraren namen van goede studenten doorgaven aan bevriende bedrijven. Vg. Jap Stoffels, open brief aan de hoogleraren der Subfaculteit Scheikunde, Vrije Universiteit" in Buletin. Kommunikatiemedium aan de subfaculteit der Scheikunde van de Vrije Unwersiteit 3 (4) (17 dec. 1970). 14.15: Guus de Boer, 'Industriedag Arnherr', in: Bulletin. Kommunikatiemedium aan de subfaculteit der Scheikunde van de vije Universiteit, 3 [8) (29 april 1971), 9-11.

5 Wetenschap en Maatschappij (Science and Society), door 123 medewerkers van het Nat.Lab. (NV. Philips' Gloellampenfabrieken, Kern, Natuurkundig, Laboratorium: Eindhoven 1973). Zle ook 'Rapport groep Philips onderzoekers'. Wetenschap \& Samenleving 74/2 (febr. 1974), 29-30,53-55.

6 "Industrieel wetenschapsbeleid" themanummeir Wetenschaps \& Samenleving 5 (7) (sept. 1973): "Wetenschap in de industrie" themanummer Wetenschap \& Samenleving 74/4 (april 1974). Vgl. Leo Molenaar, Wij kunnen het niet langer aan de politici overlaten ... De geschiedenis wan het verbond wan Wetenschappelijke Onderzaekers (WWO) 1946-1980, proefschrift Universiteit van Amsterdam (Delft 1994), 290-291, 302-307.

7 Zle ook: Ermst Homburg en Arie Rip, 'Technisch, industrieel en landbouwkundig onderzaek in Nederland in de twintigste eeuw', NEHAulaarboek voor economische, bedrifs, en techniekgeschiedemis 66 (2003), 201-207.

8 Phillp Vergragt, kees Blase en Peter Groenewegen, "Industilele laboratorla: Wetenschap \& Somenlewing 8.216.7 (juni/juli 1982), 6-7, Kees Blase. "Het Nat.Lab. in beweging. Wetenschap \& Samenheving 82/6.7 (Junl/jull 1982). 1924; Kees Blase, Het stille verzet: Wetenschap \& Samenleving 82/67 (juni/jull 1982).54-57. Sjerp Zeldenrust, "Participatie en kontrole in een ind ustrieell labo. ratorium, Wetenschap \& samenleving 82/6.7 (Juni/juli 1982), 40-43: Loet Leydesdorff, Werknemers en het technologisch vernieuwingsbeleid, provefschrift Unwersiteit van Amsterdam (Amersfoort 1984); Paul de Laat. Een kwestie wan vertrowwen. Sociale effecten war de invoering vam matrix-structuren in R\& D-organisaties een case-studie van de organisatie-ontwikkaling bif Scholten-Honig Research, proefschrift RU Groningen (Gromingen 1990). 
9 Philip Vergragt, 'Bestuitworming in industriele $R$ en $D$, Wetenschap $\&$ Samenlewing 82/6.7 (junijuli 1982), 44-48; Gerard de vries, De ontwikkeling van wetenschappelijke kennis, sociologisch beschouwd", Kenmis en methode 6 $(1982), 190$ 220, Pleter Weeder en Do Kester, "Variatie en selectie: de constructhe vam een industrieel produkt. Het geval Tenax" Kennis en methode 6 (1982). 227-251; Pl Vergragt. "The social shaping of industrial innovations". Social Studies of Science 18 (1988), 483-513; K.F. Mulder, Choosing the Caporate Future. Technology Networks and Choice Concerning the Creation of High

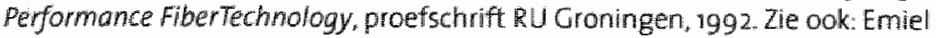
wan Kreveld, Jacob de Swaan Arons, Peter van de Loo en Jaap Naber, Shell: research en besluitvorming', Wetenchap \& Samenleving 74/4 (april 1974), 8 1.4.JC.F. Kessler, "Akzo: symthetisch leer" Wetenschap \& Samenleving 74/4 (april $1974), 22-25$.

10 Joop Schopman, "Wetenschap in bedrif: Ontwikkeling en organisatie wan het halfgeleiderondezoek binnen de N.V. Philips' Gloeilampenfabrieken 1930 1955)', Tsch. Gesch. Gnk. Natuurw. Wisk Techn. 5 (1982), 158-185. J.H.F.M. Schopman. "The Dutch contribution to barrier-layer semiconductors in the pre-germanium era', Janus 69 (1982), 128, Joop Schopman, 'Phillips' Antwort auf die neve Halbleiterăra: Germanium und silicium (1947-1957)", Technikgeschichte $50(1983)$;. Schopman. 'The Phillps' contribution to theory' and application of semiconducting oxides (1935-1950)', Janus 70 (1983). 129" 145 .

11 A. Sarlemijn, "Toepassing van wetenschap in de techniek: "brood op de plank", in: D.W. Vaags en 1. Wemelstelder (red.). Techniek, innovatie en maatschappij (Utrecht/Antwerpen 1983), 98-120; A. Sarlemijn, Tussen academie en industrie. Casimirs wisie op wetenschap en researchmanagement (Amsterdam 1984); J.J. Hutter, Laboratoria in Nederiand woor 1940 (Eindhoven 1986); 1.l. Hutter, "Nederlandse laboratoria 1860-1940, een kwantitatief overzicht, Tsch. Gesch. Gnk. Natuurw. Wisk. Techniek 9 (1986), 150-174; J). Hutter, 'Onderzoek naar hogedrukkwiklampen bij Philips;, Tsch. Gesch. Gnk. Natuurw. Wisk. Techniek 9 (1986), 242-254; 1J. Hutter Toepassingsgericht onderzoek in de industrie. De ontwikkeling van kwiklampen bij Phillps, 1900-1940. proefschrift TU Eindhoven, 9 december 1988; Peter Kroes en Martijn Bakker (red). Technological Development and Science in the Industrial Age. New Perspectivers on the Sctence-technology Rellotionship (Dordrecht 1992 ).

12 W. Wijnbeek, "Feature study naar een Shell-onderzoek", intern rapport Centrum Algemene Vorming Vrije Universiteit, 30 okt. 1974; N.J. Wijnbeak en A. Rip, Fundamenteel onderzaek in een industriele context: enkele casusstudies', manuscript RU Leiden, 27 februari 1975. NJ. Wijnbeek en A. Rip, Aanvullende gegevens over het steroiden onderzoek in Leiden en bij PhilipsDuphar" intern rapport Chemie en Samenleving Leiden, maart 1975; Loet Leydesdorff e.a. Philips en de wetenschap. Werslag wan een onderzoek naar relaties tussen uniwerstaire en industriële research in de vaste stofifysica (Amsterdam 1980): Sjerp Zeldenrust. Ambiguity, choice and Control in Research, proefschift Universiteit van Amsterdam, 18 januari 1989 . Vgl. ook Joop Schopman. The history of semiconductor electronics: A Kuhnian story?: 
Zertschnff fur allgemeine Wissenschat the orie $12(198 \mathrm{~B}), 297-302$.

13 E.SA. Bloemen, Onderzolk en ontwikkeing door het bedrifsleven in Nodertand, 1979-1939. Soctologisch instituut lelden, afstudeerscriptie, juni 1977; ESA. Bloemen" "Research, wetenschap omgezet in kapitaal: de opiomst van R\&D in Nederland" in: [Werkgroep "techniek, technologie en samenteving", Rijksuniversiteit Leiden]. Moatschoppigeschiedenis wan de techniek (whts). Collegedictaten $1977 / 78$ thd Thechnische Hogeschool Delft, 2.). 277-296, ES.A Bloemen. "Bezieling en "esprit d'équipe". Industriële research in Nedariand in het interbellum, in: P. Boomgaand e.a. (red), Exerities in ons verledem. Twadf opstellen over de economische en sociale geschiedenis van Nederland en kolo. nièn 1800-1950 (Assen 1981), 153-167.

14. H. van den Belt. B. Gremmen, E. Homburgen W. Homix, De ontwikkeling wan de kleurstofindustrie. Onderzoksproject wan het Wetenschap en samenleving. Programma van de KU. Nijmegen. Eindrapport (Faculteit der Wiskunde en Natuurwetenschappen, KU Nijmegen, apuil 1984.

15 Peter de Bruyn, Jan den Engeliman en Lennart Kik, Margarime en synthetische kleurstoffer: een terreinverkenning van het inmovatieproces, verslag van een onderwijsproject, onder begeleiding van B.C. wan Houten, G. Verbong enn $H$. Lintsen (TH Eindhoven, februari 1980), Lex Lemmens, Technische imovoties: op zoek naar een empirische theorie, intern rapport (TH Eindhoven, april 4981 ). $G$. Verbong, De ontwikkeling van de transistor bij Philips, afstudeerscriptie, onder begeleiding van H.W. Lintsen en W. de Ruiter (TH Eindhoven, mel 1981): A.M.C. Lemmens en G.P.J. Verbong. 'Natuurlijke en synthetische kleurstofenproduktle in Nederland in de negentiende eeuw', Jaarboek woor de Geschiedenis vam Bedrijf en Techmiek 19984$), 256-275$

16 HW. Lintsen en E. Homburg, Techniekgeschiedenis in Nederland" in: HW. Lintsen ea. (red.), Geschiedewis won de techniek in Nederland. De wording van een modeme samenleving, 1800-1890, deel 6 (Zutphen 1995), 254 266. Ernst Homburg, "Techniek in Nederland (TIN): de (voor)geschledenis van eet prow ject", Gewima 18 (1995), 287-295; W.J. Wolff; 'Het project; Gewina 18 (1995), 296 299: Hans Buter en Johan Schot, TIN-20 impressies. Achter de schermen wan een techniek-historisch project (Eindhowen 2003) (het daarin vermelde "beraad wan Wassenaar' (p. 5) was echter niet in de zomer van 1988, maar in april 1990).

17 Chris Boers, Wetenschap, techniek en samenleving. Bouwstenen voor een kritische wetenschopstheoric (Meppel Amsterdam 1981), aldaar 82-83, 99, 122124.

18 Armin Hermann, Whe die Wissenschaft thre Unschuld verlor Mocht und Mifbrawch der Forscher (Stuttgart 1982); lonathan Slack. 'Class struggle among the molecules", in: Trevor Pateman (red.), Counter Cours: A Hondbook for Course Critich (Harmondsworth 1972), $202-217$ Vgl. Andre Leisewitz. "Die Auswikkungen der Verwissenschaftlichung der Produktion auf die Monopolbildung und auf das Verhätnis won Okonomie und Polltik, am Beispiel der chemischen Industrie', Das Argument 14 (5/6) (Juni 1972), 444508 in het Nederlands vertaald daor onder meer wo Blanken "de huidige historicus wan philps: Andre Leisewtz, Over de gevolgen wan de werweter. 
Industrial Research in the United States; in: Richard S: Rosenbloom en Whiam I. Spencer (red. Engines of Innovation: US Industrial Research at the End of an Era (Boston 1996), 3-85. Dawd C. Mowery en Nathan Rosenberg. Paths of finrovation. Technological Change in zath-Century America (Cambridge 1998 ), 11-46.

33 NV. Nederlandsche Gist- \& spiritusfabriek Delft De ontwikkeling der ondememing in zestig jaren. 1870-1930 (Dellt 1930).52-53. B. Elema, Opkomst, evolutie en betekenis wari research gedurende honderd jaren Gistfabriek (Delft 1970), 4$34,101-111 ; 128$ Years of Gistubrocades. Harvesting the Invisible, afdruk wan power point-presentatie, $18 / 79$ mei 1998. Zle ook: Bert Theunissen, "Het nut van autonomie. Een andere kik op MW. Beijerinck's microbiologie', Gewina 17 (1994), 191-205. Pleter Bos en Bert Theumissen (red.). Beijerinck and the Delft School of Microbiology (Delft 1995). Vgl. G.P.l. Verbong en E. Homburg. "Chemische kennis en de chemische industrie', in: Lintsen e.a. (red.) Geschiedenis van de techniek in Nederland, deel 5 (Zutphen 1994), 242-269: Eaggen, Faber en Homburg, "Techniek en kennis, 1890-1970; 1157 \% 159 .

34 Jules H. Schweppe (ried). Research adn het 11: LBPMA 1914 - KSLA 1989. De geschiedenis wan het 'Lab Amsterdam' (Amsterdam 1989): Ernst Homburg. Arie Rip en James Small, 'Chemici, hum kennis en de industrie', in: Schot ea. (red.), Techriek in Nederland, deel 2 (Zutphen 2000), 298-315, aldaar 299-305. H.B.G. Casimir, Het toeval wan de werketjikheid. een halve eeww natuurkunde (Amsterdam 9983), 260-340; A. Heerding, Een onderneming wan vele markten thuis (Lelden 1986$), 384-393$ wo J.M.N. Blanken, Geschiedenis van Philips Electronics N.:. De ontwikkeling wan de N.V. Philips' Gloeilampenfabrieken tot elektrotechnisch concerm (Leiden 1992), 210-217; F.K. Boersma, inventing Structures for Industrial Research. A History of the Phillips Natlab 1914-1946. proefschrift TU Eindhowen, 25 maart 2002 (Amsterdam 2002), met name 37. 39, 185-198; Marc J. de Wries, 80 Vears of Research at the Philips Natuurkundig Laboratorium (1914-1994): The Role of the Nat Lab at Philips. interne publicatie Stichting Historie der Techniek (Eindhoven 2002), met name 45-50 (zal als boek verschijnen bij Cambridge University Press, 2004); Kees Boersma en Marc de Vries, "De veranderende rol wan het Natuurkundig Laboratorium in het Philipsconcern gedurende de periode 1914-\%994:" NEHA-Jaarboek voor economische, bedriffs-en techniekgeschiedenis 66 (2003), 287-313, aldaar 292-300.

36 Ingrid Vledder, Eddy Houwart en Enst Homburg, "Particuliere laboratoria in Nederland. deel : Opkomst en bloel, 1865-1944, NEHAwarboek woor economische, bedriffs en techniekgeschiedenis 62 (1999\%, 249-290, m.n. 253-270. Zie ook Ingrid Vledder, Ernst Homburg en Eddy Houwaart, Particullere laboratoria in Nederland deel 2: Achteruitgang, consolidatie, transfomatie, 19141950: NEHA-Jaarboek voor economische, bedrifs - en techniekgeschiedenis 63 (2000), 104-142.

37 Ernst Homburg, 'De Ferste Wereldoorlog: samenwerking en concentratle bimen de Nederlandse chemische industrie, in: Schot ea. (red), Techniek in Nederland, deel $2,316.33 \%$ : Homburg, Rip en Small, ${ }^{2}$ Chemici, hun kennis en de Industrie', 313-315; 75 laar Vondelingenplaat (Rotterdam 1976): Leverid verleden: 100 jaar Fabriek wan Chemische Producten (Rotterdam 2001); 25 jaor 
Stikstofbindingsindustrie "Nederland' NV. (Dordrecht 1946). Archef Shall, Den Haag: personeels dossier A.FA. Reijnhart Veetig jaat DRAKA. Geschedenis vam de N.V. Hollandsche Droad en Kabelfabriek Amsterdom, 1910-1950 (Amsterdamig50), 19-25.

38 Over Jurgens, zle blografieën van Chr van Loon en R.T Alting Mees, en Unillever, Historisch Archief, Rotterdam, HS 126-1122,49: correspondentie over octrool-aanvrage van P. Dujardin, ivm. regeneratie van nikkel-katalysator, 1917-1918, en idem, DIR 9-162.3: biliefwisseling tussen dr. C van Loon, NV Mij. Expl. Vereenigde Oliefabrieken, Zwijndrecht en prof. dr. J. Boeseken, mrt.-now. 1938). Over Noury, zie: C.M. Hogenstijn, van rosmolen tat chemische specia liteiten. De geschiedenis van Noury \& Kan der Lande en de beide betrokken familles (Deventer 1998), 169*177. Jasper Faber, 'Wetenschappelike kennisverwerving en diversificatie: Noury \& van der Lande, $1900-1965^{\circ}$. Scientiarum Historio 26 (2000), 217-230, aldaar 218; Faber, Kenniwerwerwing, 200-209. Over Van den Bergh, zie biografiërn S.H. Bertram en I.P.K. wan der Steur, en Unilever Historisch Archief, Rotterdam: His 5-0129: Protokoll über die 6. Chemikertagung im Van den Bergh-Konzern am 18. Dezember 1925 in Rotterdam. Over ENKA/AKU, zie: "in memoriam Ir. G.A.M. Heim", Chemisch Weekblad 41 (1945). 57-58; AKU-Research. De N.V. Onderzoekingsinstitutit "Research' van de Algemene Kunstzijde Unie NV. (Arnhem 1961); D. Vermats (red), Research bi) AKU (Arnhem 1968); Max Dendermonde, Niewwe tijden. nieuwe schakels. De eerste viftig jaren van de A.KU. (Wormerveen 1967), 56-57: Bas Klaverstijn, Samentwijnen. Wha fusie noar integratie (Airnhem 1986), 55 . Over Statsmijnen, zie: E. van Royen, Steenkolenweredeing en industriële research bij Staatsmijnen', in: HW. untsen (red.). Research tussen vetkool en zoetstof:Zestig jaar DSMI Research 940-2000 (Zutphen 2000), 12-29, aldaar 2122.

39 Tabel 1 is gebaseerd op vele bronnen, waronder gedenkboeken van de betrokken bedrijven en biografieèn van de genoemde hoogleraren. Voor samenvattende karakteriseringen, zie oa.: Chemisch Weekblad 36 (1939). 446 $450 ; 1.4$. de longh [ $=$ D. Dresden. De oorlogseditie, geschreven door de ondergedoken Dresden, werd door een vriend witgegeven], Won kaninefaat tot duzendkumstenaar (Den Haag 1941) (2e druk: 1945), 245-249: B.M. Sweers. "Toegepast-natuurwetenschappelijk onderzoek ten behaeve van de Neder. landsche nijwerheid', Economisch-Statistische Berichten, 18 juni 194. $378-38$; H. Kooprnans, vijtig jaor schelkundige nijwerheid in Nederlond (Delft 1967), 44: Bloemen. "Bezlelingen "esprit d'équipe". Unilever, Historisch Archief, Rotterdam, HIS 66-0656 656: dossiler Steger. Tie ook: E. Homburg. 'Wederwaardigheden van een katholiek scheikundige', in: $C$. Alberts en R. van Dael (red), informatica \& Samenlewing: Netwerken met Ma.r. (Amsterdam 2000), 16-18. Ower het laboratorium Zwijndrecht: biografieën H.G. Derx en H.A. Boekenoogen, en Unilever, Historisch Archief, Rotterdam, 5EC 37-843.4: H.A. Boekenoogen, "Unilever Research Laboratorium" (Zwigndrecht). Opzet en werkzamheden;, oktober 1948; R.) Taylor, A Concise History of Unilever Research in Western Europe, intern rapport Unilever. december $1967,5,6,13-15$;. Boldingh, 'Een jongensdroom kwam tot leven', in: 
Industrial Research in the United States. in: Richard S. Rasenbloom en Willam I. Spencer (red), Enghes of Innowation: U.S Industrial Research at the End of an Era (Boston 1996), 13-85, Dawid C. Moweiry en Nathan Rosenberg. Poths of Innovation. Technological Change in 2oth-Century America (Cambridge 1998), 11-46.

33. NV. Nederlandsche Gist- \& Spiritusfabriek Delft. De ontwikeling der onderneming in zestig joren. $1870-1930$ (Delft 1930), 52 -53, B. Elema, Opkomst, evalutie en betekenis wan research gedurende honderd jaren Gistfabriek (Delft 1970), 434, 101-11:; 128 Years of Gist-brocades. Harvesting the Irvisible, afdruk van power pointpresentatle, $18 / 19$ mei 1998 . Zie ook Bert Theunissen, "Het nut van autonomie. Een andere kijk op MW. Beijerinck's microbiologie', Cewina 7 (1994), 191-205, Pleter Bos en Bert Theunissem (red), Bellerinck and the Delft School of Microblalogy (Delft 1995). Vgl. G.P. Verbong en E. Homburg. 'Chemische kennis en de chemische industrie" in: Lintsen ea. (red.). Geschiedenis wan de techniek in Nederland, deel 5 (Zutphen 1994), 242-269; Baggen, Faber en Homburg, 'Techniek en kernis, 1890-1970'. 157-159.

34 Jules H. Schweppe (red.) Reseanch aan het U: LBPMA 1914 - KSLA 1989. De geschiedenis van het 'Lab Amsterdam" (Amsterdam 1989); Emst Homburg. Arie Rip en James Small, "Chemici, hun kennis en de industrie', in: Schot e.a. (red), Techniek in Nederland, deel 2 (Zutphen 2000), 298-315, aldaar 299-305.

35 H.B.G. Casimir, Het toeval wan de werkelijkheid. een halwe eeww naturkunde (Amsterdam 1983), 260-340; A. Heerding, Een onderneming van vele markten thuis (Leiden 1986), 384-393: Ivo J.M.N. Blanken, Geschiedenis wan Philips Electronics NV.: De ontwikkeling wan de NV. Philips' Gloellampenfabrieken tot elektrotechnisch cancern (Leiden 1992), 210-217) F.K. Boersma, inventing Structures for Industrial Research: A History of the Philips Natlab 1914-1946, proefschrift TU Eindhoven, 25 maart 2002 (Amsterdam 2002), met name 37. 39. 185-198; Marc J. de Vries, 80 Vears of Research at the Philips Natuurkundig Laboratorium (1944994): The Role of the Nat Lab at Philips. Interne publicatie Stichting Historie der Techniek (Elindhoven 2002), met name 45-50 (zal als boek verschijnen bij Cambridge Uniwersity Press, 2004); Kees Boersma en Marc de Vries, 'De veranderende rol van het Natuurkundilg Laboratorium in het Philipsconcern gedurende de periode $7914 \% 1994$ "NEHA-Jaarboek voor economische, bedriffs-en techniekgeschiedenis 66 (2003), 287\%313, aldaar 292-300. Ingrid Vledder, Eddy Houwaart en frnst Homburg, "Particullere laboratoria in Nederland. deel i. Oplomst en bloel, 1865-4974" NEHA Jaarboek woor economische, bedriffs en techniekgeschiederis 62 (1999), 249-290, m.n. 253-270. Zie ook: Ingrid Vledder, Ernst Homburgen Eddy Howwart:" Particuliere laboratofia in Nederland deel 2: Achteruitgang, consolidatle, transformatie, 19i41950', NEHA-Jaarboek woor economische, bedrifs-en techniekgeschiedenis 63 (2000), $104-142$.

37 Enst Fomburg, "De Eerste Wereldoorlog: samenwerkfing en concentratie birnen de Nederlandse chemische industrie, in: Schot e.a. (red), Techniek in Nederland, deel $2,316-331$; Homburg, Rip en Small, ${ }^{\circ} \mathrm{Chemic}$, hun kennis en de Industrie; 373-315; 75. Jatar Vondelingenplaat (Rotterdam 1976); Levend verleden: 100 jaar Fabriek wan Chemische Producten (Rotterdam 2001); 25 jaar 
Stikstofbindingsindustre Nedterland" WV (Cordrecht 1946), Archief Shell, Den Hag: personeels dossier A. A Reijnhart; Vertig joor DRAkH. Geschedemis van de N.W. Hollandsche Draad en Kabelfabrek Amsterdam, ng0-1950 (Amsterdamiso), $19-25$

38 Over Jurgens, zie biografieên van Chr van Loom en RT. Alting Mees, en Unilever, Historisch Archief, Rotterdam, HS 126-1122,49: correspondentie over octrooi-aanwrage van P. Dujardin, i.m. regeneratie wan nikkel-katalysator, 1917-1918, en idem, DIR 9-162.3: briefwisselimg tussen dr. C. van Loon, NV Mij. Expl. Vereenigde Oliefabrieken, Zwigndrecht en prof, dr. J. Böeseken, mnt-now. 1938). Over Noury, zie: C.M Hogenstijn, Van rosmolen tot chemische specia liteiten. De geschiedenis van Noun \& Van der Lande en de beide betrokken familes (Dewenter 1998), 169-177, Jasper Faber, Wetenschappeilike kenniswerwerving en diversificatie: Noury \& wan der Lande, 1900-1965". Scientiorum Historia 26 (2000), 217-230, aldaar 218, Faber, Kenniswemerving, 200-209. Over Van den Bergh, zie biografiexen S.H. Bertram en J.P.K van der Steur, en Unilewer, Historisch Archief, Rotterdam: HIS 5-or29: Protokoll über die 6. Chemikertagung im Van den Bergh-Konzern am 18. Dezember 1925 in Rotterdam. Over ENKAAKU, zie: 'In memoriam Ir. G.A.M. Heim', Chemisch Weekblad 41 (19.5). 57-58; AKU-Research. De NV. Onderzokhingshnstitut 'Research' wan de Algemene Kunstzijde Unie N.V. (Arnhem 1961); D. Vermaas (red.), Research bij AKU (Arrhem 1968); Max Dendermonde, Nieuwe tijden, mieuwe schakels. De eerste wiftig jaren van de A.K.U. (Womerveer 1961), 56-57: Bas Klaverstijn, Samentwijmen. Via fusie naar integratie (Ambem 1986), 55. Over Statsmijnen, zle: E. wan Royen, "Steenkolenveredeling en industriele research bij staatsmijnen', in: H.W. Lintsen (red. . Research tussen vetkool en zoetstof: Zestig jaar DSM Researchr940-2000 (Zutphen 2000), 12-29, alldaar 2122.

39 Tabel I is gebaseerd op wele brommen, waronder gedenkboeken wan de betrokken bedrijwen en biografieen warn de genoemde hoogleraren. Voor samenvattende karakteriseringen, zie 0.a.: Chemisch Weekblad 36 (1939), 446$45 \mathrm{O} ; \mathrm{H}$. de longh $\mathrm{l}=\mathrm{D}$. Dresdlen. De oorlogseditie, geschreven door de ondergedoken Dresden, werd dooi een wriend uitgegeven], Van kaninefaat tot duizendkunstenaar (Den Haag 1941) (2e druk: 1945). 245-249; BM. Sweers, 'Toegepast-natuurwetenschappelijk onderzoek ten behoeve van de Nedier. landsche nijverheid' Economisch-Statistische Berichten 18 juni 194.1, 378-381; H. Koopmans, Viftig joar scheikundige niwerheid in Nederland (Delft 1967), 44: Bloemen, "Bezieling en "esprit d'équipe".

Unillever, Historisch Archief, Rotterdam, HAS 66-0656 656: dossier steger. Zle ook: E. Homburg, "Wederwardigheden van een katholek scheikundige; in: $G$. Alberts en R. van Dael (red.), Informatica \& Samenteving: Netwerken met Mar.c. (Amsterdam 2000), 16-18. Over het laboratorum Zwilndrecht: bio grafieenn H.G. Derx en H.A. Boekenoogen, en Unillever, Historisch Archief, Rotterdam, 5EC 37-843. H: H.A. Boekenoogen, "Unilewer Rescarch Laboratorium' (Zwijudrecht). Opzet en werkaamheden; oktober 1948; R. Taylor A Concise History of Unilever Research in Western Europe, intern rapport Unilever, december 1967,5-5,13-15;. Boldingh, 'Een jongensdroom kwam tot leven', in: 
Werken qun sthehtunde, 265-291, aldaar $27-275$. Er is weinig geptoliceerd over de geschiedenis wan de research bij Unilever. Het interne rapport van Beek is tameljk zwalk wat betreft de geschiedschrijwing van de periode wón 1945. Zie: W. Beelk. History of Research and Engineering ot Unilever $1917-1986$ (Miatardingen, augustus 1996).

41 Schweppe (red.), Research aan bet $14,29-32,75,80-82$; De Vries, 80 Years of Research, 41-42,44.

42 Blanken, Geschiedenis wan Phillps Electronics NV, 213-217: De Vries, 80 Years of Research. 41-44.

43 Hogenstijn, Wan rosmolen tot chemische specialiterten, 70,178 ; Faber; "Wetenschappelike kenniswerwerving, 218; Faber, Kennisverwerving, 209-210.

44 Ernst Homburg, James, Small en Plet Vincken, "Van carbo naar petrochemie, 1910-1940", in: Schot ea. (red). Techniek in Nederland, deel 2.332-357, aldaar 351-357: Sichweppe (red.), Research aon het $1,49-52,60-62$. Archief shell, Den Haag, inw no. 190D, nr. 893: personeelsdossier AJ van Peski.

45 Schweppe (red), Research aan het $U, 33,47,52,75$, Boersma, Inventing Structures for Industrial Research, 223:44-149. De Vries, 80 Vears of Research. $10,44:$ " 50 jaar Arla", De Spindop (30 jan. 1976). 5; Klaverstijn, Samentwijnen, 55.

46 Schweppe (red), Research aan het $11,47,79-82.95$. Boersma, Inventing Structures for Industrial Research, 224; 147-149; De Vries, 80 Vears of Research, 10, 44: C.C.D. Maarschalk, The Role of Potents in Technological Progress with Special Attention to Patent Activity in the Netherlands, proefschrift NEH Rotterdam, 18 maart $1948,37-3,8$; Bloemen, "Bezieling", 156. Jan Luiten van Zanden heeft Bloemen sloirdig gelezen en stett ten onrechte dat de Grote Viff in de jaren dertig tezamen wiftig procent vall de industriele R\&D voor hun rekening namen. Zie: JL. van Zanden, Een klein land in de zoe eeuw. Economische geschiedenis van Nederland 194-1995 (Utrecht 1997), 63.

47 Khaverstin, Samentwijnen. 55: Elema, Opkomst, evolutie en betekenis van research, 103; Unilever, Historisch Archief, Rotterdam, OIR 9-167.3: Personeelsbezetting NV Maatschappij tot Exploitatie der Vereenigde Olefabrieken Zwijndrecht, op 2 januari en 1 december 1937.5 taatsmijnen, zie noot 48 .

48 Rijksarchief Limburg, Mastricht (hierna RAL): archief DSM 17.26/34, inw. 664: "Tegenwoordige personeelssterkte der Staatsmijnenlaboratoria (1 Januari 1938)"; $17.26 / 36 \mathrm{~A}$, irw 1 : G. Berkhoff; "Enkele gegewens betreffende de werkamheden in het Centraal Laboraturium gedurende het jaar 1941": 'Dertigjar Centraal Proefstation', Stcatsminen "59 (nov, 1959).4-19. Over het laboratorium van het Stksstofbindingsbedrijf als 'kiramkamer' vam de research bij Staatsmijnen, zie: Arjan van Roolj, Aangekochte technologie en industriele research bij het stikstofbindingsbedriff van Staatsmijnen in de Jaren 1930; NEHA-Jaurboek woor economische, bedriff- en techniekgeschiedenis 66 (2003), 263-286: Baggen, Faber en Homburg, Techniek en kennis. $1890+1970^{\prime}, 156+157$

49 D.C. Mowiry, The Emergence and Crowth of Industrial Research in American Manufactwing. 1899-945, proefschrift Stanford University 1981; David C. Mowery en Nathan Rosenberg, Technolagy and the Pursuit of Economic 
Growth (Cambridge/ New York 1989).61-74. Hounshell. "The Evolution of Industrial Research; 30 .

50 RAL, archief DSM: 17.26/36A, inv. 1: F van Herson, Aantekeningen betreffende research-laboratoria, 22 juni, 23 juni, 8 juli, 18 jull, 7 augustus en 3 november 1936. Wgl. Vam Royen, "Steenkolenveredeling en industriele research" 22-23.

51 EA. Möller, veertig jaor zwelstiff elfabricage bij Schalten's Chemische en wat eraan wooraf ging (foxhol 9962$), 43-46,52-56,63,75-76$.

52 1.H. wan der Steen, 200 jaar Sikkens (Sassenheim 1991), 21-32, 41: C.P.A. Kappelmeier, Modeme lakverwen: Bereiding, eigenschappen en verwerking (1945). 85 90: Mark Pier, De som van het verleden: De geschiedenis wan een verfoedriff' (Sigma Coatings: Uithoorn 1997). 9; R.M. Sprenger, Ten behoeve van de gezondheid wan mens, dier en plont:. De geschiedenis war Duphar 1930 . 1980 (Solvay Duphar: Weesp 19921, 26-29, 43-46, 50,52-53,56; Dr. A.G. de Boer" Chemisch Weekblad 36 (1939). 111; "Geschiedenis der N. Amsterdamsche Chininefabriek 1881-1940", typoscript, Amsterdam 1940, in bezit wan de auteur, 40-42; Marius Tausk, Organon: De geschiedenis wan een bijzondere Nederiondse ondernerning (Wujmegen 1978), $15,1-156,251,338,399$.

53 "Polak, Dr. James Joseph", in: Persoonlijkheden in het Koninkrik der Nederlanden in woord en beeld (Amsterdam 1938), $164-1165$; AKU-Research; Dendermonde, Nieuwe tijden, nieuwe schakels; 56-57; Archief Akzonobel, Arnhem: notulen der vergaderingen van de Raad wan Bestuur en van Aandeelhoudiers van de N.V. Research, 28 februari $934 t / \mathrm{m} 5$ april 1956.

54 Archief Shell, inv no. 190D, nr. 838: personeelsdossier JW.H. Uytenbagaiart; Chemisch Weekblad 38 (1941), 226; Ohe 3 (maant 1950); Olie 4 (1950/51), 206: Olie (juni 1957).

55 Andere voorbeelden zijn de overstap wan D.W. van Krevelen van Staatsmingen naar AKU, in 1959, en die van D.A. wan Dorp van Organon naar Unilever, even eens in 1959.

56 Homburg, Rip en Small, 'Chemici, hun kennis en de industrie', 308-313; Baggen, Faber en Homburg. "Techniek en kennis, 1890-1970, $360-164$; Bert Theunissen en Frans wan Lunteren (red.), 'Zuiwere wetenschap en praktisch nut Visies op de maatschappelijke betekenis van wetenschappelijk onderzoek rond 1900" Gewina 17 (1994), 141-205; H.G. Heijmans, Wetenschap tursen universiteit en industrie. De experimentele natuurkunde in Utrecht onder WH. Julius en LS. Ornstein 1896-7940, proefschrift Universitet Utrecht, 1994 (Rotterdain 1994); Gu. Somsen. "Wetenschappelijk onderzok en algemeen belang. De chemie van H.R. Kruyt (1882-1959), proefschnif Universtelt Utrecht, 27 april 1998; Peter Jan knegtmans, "Onderwis, weterschap en particulier initiatief aan de Universiteit wan Amsterdam, in: P. Knegtrmans en A.J. Kox (red.). Tot nut en eer wan de stad. Wetenschappelijk onderzoek dan de Unwersiteit wan Amsterdam (Amsterdam 2000), 79-105, 1 H. van Lunteren, "Uit cie ivoren toren: Nederlandse natulurvetenschappers in het interbellumi. inaugurele rede Vrije Universitieit, Amsterdam, 5 jun 2003.

57 [C.J. van Nieuwenburg, e.a.]. De oogst een overzicht wan het wetenschappelijk werk wan Prof. dr. ir. H.J. Waterman, te zamen gebracht ter gelegenheid wan zijh aftreden als hoogleraar in de chemische technologie aan de Technische 
Hoogeschool te Delf (Delft 1959), H. Waterman, Ontwikkeling van de chemische industrie en het chemisch onderzoek, Chemisch Weekblad 55 (1959), 309 " In memoriam Professor Dr. H. Waterman, 28 april 1889-3 februa-

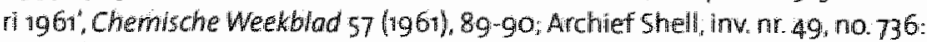
dossier Waterman; Rijksarchief in Zuid-Holland: De Archieven van de Technische Hogeschool te Delft, Inv nr. 939: Stukken betreffende cen verzock van professor Waterman, hoogleraar chemische technologle, om zijn uitvinding op het gebied wan de chemie an de Imperial chemical industries over te dragen, 1934-1935. Whet dankan James small.

58 Het idee om op kosten van de industrie "rijwerheidslaboranten' te laten werker in de laboratorla van de TH Delft ontstond vak voor de terste Wereldoorlog, natar Amerikans voorbeeld: lasper Faber, 'C.J. van Neuwenburg over organisatie van wetenschappelijk-technisch werk", Gewina 21 (1998), 15-29, aldaar 22-24: Gi de Clercq. "Techniek en universitet",

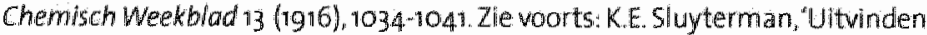
en verdienen. De basisvan de Oce kopleer-activiteiten geanalyseerd, 1918 1956: in: H.FJM. van den Eerenbeernt (red.), Von boterkleursel noar kopieersystemen. De ontstaansgeschedenis van Océwan der Grinten, $1877-1956$ (Leiden 1992), 171-264. aldaar 193, 205-206; Hogenstijn, Van rosmolen tot chemische specialiteiten, 167-168, 201-202; Archief Shell, invmr. 190A, no. $7 \%$ "NV. Fabriek van Chemische Producten, 1901,16 februari - 1951. "Wondellngenplat 50 jaar", typoscript. 9 .

59 Tausk, Organon, 11-156; Nelly Oudshoom, Beyond the Natural Body. An Archeology of Sex Warmones (Londen en New York 1994), 65*111; Jeroen Verhoog.75jaar Organon, 1923-1998 (Noordwijk 1998), 17-4.;: Nelly Oudshoorm, "Laqueur en Organori. Het unversitaire laboratorium en de farmaceutische industrie in Nederland", Gewina 22 (1999). 12-22; Knegtmans "Onderwijs, wetenschap en particulier initiatief", $90 \% 94$.

60 [D.A. van Wittop Koning, e.a.], N.V. Koninkljke Pharmaceutische Fabrieken w/h Brocades-5theeman \& Pharmacia 7800-1950 (Amsterdam 1950). 46-51; "Het nieuwe researchlaboratorium wan Brocades', Chemisch Weekblad 55 (1959). 9-12: [llse van Goozen], van plattelandsapotheek tot Europees bedriff. Hoe Brocades Vamonouchi werd. Een beknopte bedrifsgeschiedenis wan 1798 tot 1995 (Leiderdarp 1995.) 26-36. Over de geschiedenis wan het in 19418 geopende bedrifflaboratorium van Brocades in Meppel, war slechts op bescheiden sctial research werd vericht, zle ook: rony de Ridder, NV. Kon. Pharmaceutische Fobriek woom. Brocades \& Stheemam, Meppel (Amsterdam 1918), 12, 16; Thijs Rinsema, "Brocades 8, Stheeman. Van apotheker fabrikant tot farmacautische industrie', Gewina 22 (1999), 23-33: Thijs Jan Rinsema, De natutir woorbij. Het begin van de producte van synthetische geneesmiddelen, proefschrift Universiteit Leiden, 14 september 2000, 339-402.

61 Bakhuis Roozeboom-Herdenkingssymposium', Chemisch Weekblad 51 (4955). 400-442; Vani Rooll. 'Aangekochte techrologie', 274-278: Judith Schotman, "Fasenleer: fundament wan de procesindustrie" Chemisch Weekblod (16 olkt. 1980), 456; Geert I. Somsen, "Faith and the phase rule: H.W. Bakhuis Roozeboom's Calvinist chemistry and its place in Dutch professional research 
Cal. 1900", interne paper Faculteit Cultuuwetenschappen , Mastricht 2003 M.M.RJ. PUsjé, Physisch-chemische onderzoekingen over het antslwiten wan ruw fosfact met salpeterzur, proefschnft TH Delft, 22 mei 1946; PJC. Kaasenbrood, "The urea stripping process. The technical manufacture of urea. with carbon dioxide used both as reactant and as stripping gas: in: Proceedings of the fourth Eurapean symposium on Chemical Reaction Engineering, Brussels, 9-11 Septen ber 968 (Oxford 1971), 317-328, "Een kapitale uitwinding die het meestuerkochte Stamicarbonproces opleverde. Then Jar geleden zette DSM de eerste ureumstripfabriek ter wereld neer: DSM Magazine nr. 20 (juli 1977), 18-22. Vgl. Carsten Reinhardt, "Basic Research in Industry: Two Case Studies at 10 Farbenindustrie $A G$ in the 1920 and $19305^{\circ}$ in Travis, Schröter. Homburg en Morris (red.). Determimants in the Evolution of the European Chemical industy, 67-85. aldaar 85 .

62 Boersma, Inventing structures for Industrial Research, 147-349.

$63 \mathrm{Vgl}$. Frans van Steijn, The University in Society. A Study of Part-time Professors in the Netherlands, proefschrift Universitet van Amsterdam, 15 juni 1990.

64 Ernst Homburg en Lodewijk Palm (red.). De geschiedenis van de scheikunde in Nederland. Deel 3: De antwikkeling wan de chemie wan 1945 tot het begin wan de jaren tachtig (Delftse Universitaire Pers, te verschijnen).

65 De gepresenteerde getallen zijn 'full time equivalenten' (ftess), omdat onder zoekers die bijwoorbeeld een deel wan hun carriere bij phillips en een ander deel aan de universiteit Utrechtwerkten, bij beide instellingen slechts voor 0,5 zijn geteld. Het totale aantal "toponderzoekers" wit deze populatie wan 147 personen dat ooit werkte bij Shell is 24, bij Philips 13 , bij Akzo en haar woorlopers (AKU. Organon. Noury) 12 en bij DSM (excll. Gist) 10 (en bij Unilever 3). De cijfers warn Gist en DSM zijn niet bij elkaar opgeteld, omdat de fusie tussen beide bedrijven ná de hiver onderzochte periode (1945-1995) platatswond.

66 Henk van den Belt en Arie Rip. 'The Nelson-Winter-Dosi model and symthetic dye chem istry', in: Wiebe E. Bijker, Thomas. P. Hughes en Trewor 1 . Pinch, The Social Construction of Technological Systems: New Directions in the Sociology and History of Technology (Cambridge. MA ig87). 135-158, aldatar 154*155.

$67 \mathrm{Vgl}$. Arie Rip, "De gans met gouden eieren en a mdere maatschappelijke legitmaties van de moderne wetenschiap", De Gids 145 (1982), 285-297; G. Pascal Zachary, Endless frontiev: Vannewar Busn, Engineer of the American Century (Cambridge, MA 1999).

68 TJ. Twijnstra, Openingswoord, in: Redevoeringen, witgesproken tjders het Research-Congres (...) gehouden op 16 en 17 october 1947 (2. p., 2.j), $7-3 ;$;. Holst. "Noodzaak en betekenis deir research", in: idem, $7-13$, aldiar 12 .

69 G. Wise, A new role for professionall seientists in industry: industrial research at General Electric, 1900-1916', Technology and Culture 21 (1980), 408-429; L. Moddeson, "The emergence of basic research in the Bell Telephone System, 1875, 1915. Technology and Culture 22 (1981), 512-544; Wise. Wills R. Winey; Hughes, American Genesis, 159-183: Hounshell, "The Evolution of industrial Research" 34-41, 45. Albert Rosenberg. The Quintessence of Irving Langmwir (Oxford 1966 ).

70 John K. Smith en David A. Hounshell, Wallace H. Carothers and fundamental 
research at Du Pont, Science $229(1985), 436442$; David A. Hounshell en John Kenly Smith ji, Sclence ond Corporate Strategy: Du Pont R\&D, 1902-1980 (Cambridge 1988). 223"248; Urich Marsch, "Strategies for success; Research organization in German chemical companies and lC Farben until 1936" History and Technology 12 (1994), 23-77; Pilar Barrera, "The evolution of corporate techmological capabitities: Du Pont and 10 Farben in comparative perspective", Zeitschrift fir Unternehmensgeschichte 39 (1994), 31-45; Reinhardt, 'Baslc research in industry.

7 Paul Smith, 'Industrie gedwongen tot LATrelatie', Chemischaweekblad (19) mei 20011), 6-7.

72 Holst "Woddaak en betekeris der reseanch" "n

73 Ook qua inventiviteit - gemeten althans in aantallen octroolen - liep Philips lange tijo voór op de BPM, ondanks het feit dat dat laatste bedriff een grote R\& D-organisatie had. Zle: Maarschalk. The Role of Patents in Technological Progress, $27-28$ en graph 16.

74 Holst, 'Noadzaak en betekenis der research', 11; Sprenger, Ten behoeve van de gezoniheid van mens, dier evi plant", 66, 85-87, 102-103; Boersma, Inventing Structures for Industrial Research, 172; De Vries, 80 Vears of Research, 40-41; MP. Rappoldt: "Van scheepjeswol naar vitamine D', in Herman van Beklkum en dain Reedilk (red), Chemle achter de dijken (Amsterdam 2001), 32-33. Wo Blanken - Geschiederis van PhWips Ejectronics N.V. 333 \%37 - geeft milns inziens geen juist beeld van het enthouslasme van Holst over deze ontdekking.

75 [A.J. Mountvala, m.m.v. G.W. Rathenau], "Magnetic ferrites, un: [Herman Loellbach (red.)], Technology in Retrospect And Critical Events in Science (TRACES), (IIT Research unstitute: Dec. 1968-Jan. 1969), deel 1, 28-40, deel 2 , 9-24: JTh Overbeek en G.W. Rathenau, 'E. .W.W. Verwey" Bij zijn aftreden als directeuir wan het Philips Natuurkundig Laboratorium, Chemisch Weekblad 63 (1967).37: H.A.M. Snelders, De geschiedenis van de schelkunde in Nederland 2: De ontwikkeling wan chemie en chemische technologie, 1900-1950 (Delft 1997). $113-117,176-180$; De Vries, 80 Vears of Research, 36-40, 81-87; Boersma, Inventing Structures for Industrial Research, 54-57, 59, 135-137. Vgl. Blanken, Geschieden is wam Phillps Electronics N.V.,33-334, 1.J. Blanken, Een industriéle wereldjederatie (Zaltbommel 2002), 120-124.

76 Zie ook: G. Holst, "Industrielaboratoria' (inaugurele rede). Physica 10 (1930), 3" 46; Blanken, Geschedenis van Philps Electronics NV, 210-213, 333-334.

77 A.E. van Arkel, Afscheidscollege als hoogleraar in de Anorganische Chemie te Leiden, 29 meil 1964; Chemisch Weekblad 60 (1964), 573,578; E. W. Werwey, A.E. van Arkel', Chemish Weekblad 16 april 1976 "EJW. Verwey. 'H. He Boer en de anorganische en fysische chemie', Chemische Weekblod 65 (27 juni 1969), 13-15.

78 Meyer-Thutow, "The industralisation of linention; A. Kneteman, In memorlam 10. H.C. Jacobsen; chemisch Weekblad 48 (1952). 333-334: FI. Tempel, "Wetenschappelijk onderzoek bij Unilever", Chemisch Weekblad 53 (1957), 236 . 240; A.FH. BlaauW, "De organisatie van de research bij een groot concerm: Chemisch Weekblad 61 (1965), 33-35i J. Boldingh, Lipiden, wachters aon de poort, in augurele rede Rijksuniversiteit utrecht, 7 febr. 1966 (ook in Chemisch Mereklad. 
79 EW. Gorter en FC. Romeyn, A.E. van Ankel: On the occaston of his retirement from the chair of norganic chemistry at Leyden University., Chemisch Weekblad 60 (1964), 298-308; Van Arkel, Afscheidscollege: EIW Verwey (en WG. Burgers). Levensbericht van Anton Eduard van Arkel (19 november 1893-14 maart 1976)', Koninklike Nederlondse Alademle van Wetenschoppen. Joarboek 1976 (Amsterdam 1977). 184-192; Judith Schotman, "Nederland als katalysator van de katalyse. Prof. Schuit met emeritatat', Chemisch Wrekblad (5 mrt. 1981); Werken aun scheikunde 24 memaires van hen die de Nederlandse chemie deze eeww groot hebbem gemaakt (Delft 1993 ), 100, 174-176, 246-247 $295-298$.

80 Taylor, A Concise History of Unilever Research, vO-12, Verwey. "H. de Boer"; G.C.A. Schuit, 'I.H. de Boer en de heterogene katalyse, Chemische Weekblad 65 (27 juni 1969), 19-23; H.M. Snelders, 'Boer, Jan Hendrik de; fri: J: Charté en A.JCM. Gabrieis (red.), Blografisch Woordenboek won Nederhand, deel 4 ('5-Grawenhage 1994) 45-47. Daanaast werkte Statsminen met externe adviseurs. De eerste adviseurs waren A.M.J.F. Michels, 1942-1967, H.l. Waterman, 1950-1959? en FLI. Sixma, 1956-i959. Zie. Centrat Archief DSM. Heerlen: personeelsdossiers van A.M.J.F Michels en FJ.L. Sixma, met name de brief van DW. van Krevelen aan Directle Staatsmijnen, 29 februari 1956 , in het dossier-Sixma.

81 JJ.F. Scholten (red.), A Short History of the Dutch School of Catalysis (Den Haag 1994), hierin met name: I.J. Steggerda, "The Delft school of catalysis of J.M. de Boer (1946-1969)', 83-86; Jan W. van 5pronsen, 'De Delftse school voor katalyse: EChO $7(1998), 49-54$.

82. G.F.te Roller, Een halve eeuw Centraal Laboratorium. Een serie gesprekken met oud-researchdirecteuren van DSM, intern rapport, Heerlen, maart 1990,6.

83. Archief Akzo-Nobel notulen der wergadering van de Rad van Bestuur van de NV. Research, 15 dec. 1941; AKU-Research, 73-74; D. Vermaas, "Bij het 25-jarig doctoraat van Dr. Ir. P.H. Hermans", Chemisch Weekblad 45 (1949), 181-183; G. Challa en D. Heikens, "Bij het afficheid van Dr. Ir. P.H. Hermans", Chemisch Weekblad 59 (1963), 177-179; C. Challa, "Veel meer polymeer", in: Werken aon scheikunde, $465 \cdot 482$, aldaar $466-468$.

$84 \mathrm{Vgl}$. ook thet fundamentele werk van $\downarrow$, Verheus, FJ. Zuiderweg en H. kramers bij de BPM gedurende de oorlog, dat van DW. van Krevelen bij Staatsmijnen, en dat van H.B.G. Casimir bij Philips. Interviews $\mathbb{E}$. Homburg en 1.5 . 5 mall met: H. Kramers, DW. wan Krevelen en F. Zuideweg in 1997; Te Roller, Een halwe eeuw Central Laboratorium, 4, 12-13; Casimir, Het toeval vam ae werkwilkhed. $268-269,276-277$.

85 intervew E. Homburg en I.S. Small met Ir. E. van Andel te Boekelo, 31 juli 1997 (de vader van Noor van Andel, zle onder); De Spindop 8 (36) (22 aug, 1952), $5-6$.

86 Schweppe (red.), Researth aon het 11, 91-117; interview E.E. van Andel, 31 jull 1997: AKU Nieuws, no. 13 (26 juhi 1945): AKU Niewws, ro. 16 (16 aug. 1945): Elema, Opkomst, evolutie en betekenis wan research, 34-39; Quest intermational Nederland, Bedrifsarchief, Naarden: WA. van Dorp Ir "Geschiedenis NV. Chemische Fabriek "Naarden" 1905-19.5' (aamwezig als manuscript en typoscript), 43-44, 46; Th.J. van Kasteel, 'Ontstaan en groel van TNO', in: Een kwart 
eeuW TNO, 1972-1957 (Den Hag 1957), 1-39, aldaair 25-26; PE. de Hen, Actieve en reactieve industriepolitiek in Nederland (Amsterdam 1980), $251252 ; \mathrm{H}$. Benninga, A History of Lactic Acid Making: A Chopter in the History of Blotechnology (Dordrecht 1990), 342-343,349-350, 379, 395; schotman. "Nederland als katalysator". Zie ook: Archef shell: personeelsdosisier JWH. Uyterbogart, en Jan Al, Research als overheidstaak, proefschrift TH Delf, 9 jull 1952 (promotor W.H. Uytenbogaart).

87 Elema, Opkomst, evolutie en betekenis wan reseorch, 105-109, 114.

88 Boersma en De Vries, 'De veranderende rol van het Natuurkundig Laboratorium; 299; Boersma, Inventing Structures for Industrial Reseanch, 69$73,22,4,1$. Blanken, Onder Dults beheer (Zatbonmel 1997), 265-266; Blanken, Een industriele weveldfederatie, $122-123$; De Vries, 80 Vears of Research, 90-98; Casimir, Het toeval wan de werketijkheid, 237-244, 268-269, 27, 276-277. 336337; Werken aan scheikunde, 121-122, 177-179, 270 271; interview E. Homburg en 1.5. Small met C. van Heerden, Maastricht, april 1997: interview E. Homburg en J.5. Small met IM.L. Janssen, Erischede, zi jult 1997.

89 Over de situatlie in Amerika zie: Hounshell, "The Evolution of Industrial Research, 42-50; Mowery and Rosenberg, Paths of Innovation, 38-46.

90 Boersma en De Wries, 'De veranderende rol van het Naturkundig Laboratorium; 287 ; Edwin Kisman en Fridus Valkema. Toepasbarheid is een strategisch doel voor thet uniwersitaire onderzoek. Philips" research coördina. tor Feje Meljer neemt afscheid", chemisch Weekblod (19 juli 1997): Van Royen, 'Steenkolenweredeling en industriéle research', 27; H. Lintsen, T. wan Helwoort en P. Vincken, Intermezzo: Research en de opbouw wan een chemisch con. cern, in: Lintsen (red), Research tussen vetkool en zoetstof, $60-69$.

91 Bibliotheek DSM Research, Geleen: Reis wan Team Nr. $38 \mathrm{Am}$ van de Nederlandse Militaire Missie na rapp. 7795 , d.d. sept. 1947 look in Algemeen Rijsarchief (ARA), Den Haag: 2.06.042, doos 88); RAL: archlef OSM, 17.26/36A, inv. 99: "Discussie colloquium 10 Jan. 1948. (Discussie Rapport Ludwigshafen CL No. R. 1795) (ook als bijlage bij CL 1795 in bibliotheek CL): Centraal Archief DSM, Heerlen: personeelsdossier $H$ de Bruijn. Vgl. Schweppe (red.), Research aan het 4 , $133-136$, en Archief Shell, inv nr 19oA/nr. 179:A/1: Minutes of Meeting held in London on Maly 15t, 1946; over 0.a. de fundamentele research wan de Groep in Amsterdam, Delft en Emerywille.

92 Te Roller, Een have eeuw Centraal Labaratorium, 7, 15, 28, 30; Lintsen (red), Research tussen vetkool en zoetstof, $25-29,60-69,88-89$.

93 Casimil, Het toeval van de werkellikheld, 282. De Viles, 80 Years of Research. $102-107.122-125$. Vgl. Blanken, Een industriele wereldfederatie, $123-153$.

94 Archief Akro Nobel notulen der vergadering wan de Raad van Bestuur van de N.V. Research, 5 april 1956; 5 chweppe (red.), Research aon het $14,124,125,134$, 187, 209; Unilever Archlef, H15 239-1078: meeting Research Committee. Friday 26th August, 1955; Unilewer Research (Rotterdam 1961), 9; Lintsen (red.). Research tussen vetkool en zoetstof, 26-27: Elema, Opkomst, evolutie en betekenis var reseorch, 103. Zle ook: H.R. Kruyt, 'Research in Nederland woór vijftig jal en mu: Chemisch Weekblad 49 (1953), 578-581; H. de Boer, De chemicus 
en zijn collega's: Chemisch Weekblad 51 (1955). 245-250: CuF Bottcher, "Natuumetenschappelikk onderzok in uniwersitair en industriee verband", Chemisch Weskblod 54 (1958), 245-218; JH de Boer "De stuatle van de chemische research in Nederland", Chemisch Weekblad 54 1958), 507-512: "R \& D bij de Grote Wifi: WWO-enquete bij Akzo, DSM, Phillps, Shell en Unilever". Wetenschap \& Samenleving $74 / 4$ (april 1974), 59-71.

95 Verhoog, 75 jaor Organon, 79: Emst Homburg. "Organon", Wetenschap \& Samenleving 82167 (junl/juli 1982), 28-31; Sprenger, 'Ten behoeve wan de gezondheid van mens, dier en plant? 66

96 Blanken. Een industriele wereldfederatie, 147.

97 Schweppe (red), Research aon het U, 134, 179-183, 187-188, 196-197, 209: 'Opening wan het nieuwe gebouw van het Kon./Shell-laboratolum te Amsterdam; Chemisch Weekblad 49 (1953). 874-877. Vgl. [Shell Research BV], Koninklijke/Shell-Laboratorium, Amsterdam (Arnsterdam 1976), 5. 18, 20; [5hell Internationale Research Maatschappij BV], Shell Research (Londen 1986), 19; [Shell Research BV], Koninklijke/Shell-Laboratorium, Amsterdam (Amsterdami $1987), 7$.

98 'Eerste paal Researchlaboratorium Unilever N.:. Chemisch Weekblad 49 (1953), 265: Unilever Research Laboratorium Vlaardingen (Vlaardingen, nowember 1956): "Het nieuwe Unilever Research Laboratorim te Vaardingen", Chemisch Weekblad $52(1956), 839-844$; Fl. Tempel, Wetenschappelijk anderzaek bij Unilever. Rede gehouden in de algemene vergadering wan aandedhouders op 25 april 1957 (Rotterdam 1957) (ook in Chemisch Weekblod): NNieuw research laboratorium wan Unilever, Chemisch Weekblad 59 (1963), B93; Blaauw, 'De olganisatie wan de research bil een groot concern':

$99 \mathrm{Vgl}$. [Commissie Roeterink], Toekomstige behoefte aan ingenieurs en hum opleidingsmogelijkheid (Utrecht, november 1948); Ph.J. Idenburg, Menswm gevraagd! inaugurele rede Universiteit van Amsterdam, 1 oktober 1956 ; [Commissie Dalmulder], De ontwikkeling wan het aantal academici to 1980 : aanboden behoefle (zeist 1959).

100 Voorbeelden zijn EC Kooyman, E.L. Mackor, C. Maclean.

101 [A.F.A. Reynhart], De proeffabrieken voor physische en chemische technologie van de Technische Hogeschool te Delft (Den Haag 1951). 7-8; [A.F.A. Reyrhart]. De modernisering van het Kamerling h Onnes laboratorium der Rijksunwers iteit te Leiden (Den Hag 1952) J.). Broeze, Bij de officiale Ingebrulktelling der nieuwe T.H laboratoria", Olie. Nederlands Maandblad woor het personeel wan de koninklijke/shell Groep 4 (6) (malrt 1951). A.F. Kamp, De Technische Hogeschoof te Defft, ngo5-1955 ('s-Gravenhage 1955), 114-116, 118, 120, 283 . Archlef, Shell, inv no. 74: Hoger onderwigs (lab. Delft en Leiden, studiebeurzen).

$102 \mathrm{H}$. Baudet, De hange weg naar de Technische Universiteit Delft (Den Haag 1992), deel 1,$461 ;$ Harrie $E$ A wan den Akker en Chris $R$. Kleijn. Het gewicht wan de Witte Olifant: 50 jaar Kramers Laboratorium voar fysische Technologie. 1949 1999 (TU Delft: Delft 1999 ); interwew E. Homburg en 1.5 . Small met $H$ Kramers, Rheden, 4maart 1997; interwiew Gerard Alberts en Fons Alkemade met H. Kramers, 9 januari 1998. 
103 Baudet, De lange weg. deel 2, 747-748; Pleter Calje, 'Proximity without propinquity? De verschuivende relatie tussen de stad Delft en het polytechnisch onderwijs in de negentiende en twintigste euw', Gewina 24 (2001), 60-73. aldaar 69. Zie ook: Hugues C. Boekrad, Mlchel I van Nieuwstadt; Ton Regtien en Henk Sips, Universiteit en ondememing een andyse wan het rapport Maris (Nijmegen 1968), 18-19.

104 [Stichting Scheikundig Onderzoek in Nederland], Jaorverslag 1973

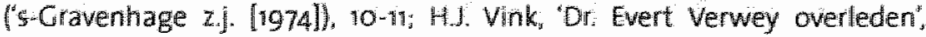
Chemisch Weekblad (s mit. 1981), 79; H.J. Wink, 'Levensbericht van Evert Johannes Willem Verwey 30 april $1905-13$ februan $98 \%$; Koninklike Nederlandse Akademie wan Wetenschappen. Jaarboek 1981-1982 (Amsterdam 1982), 166-177, aldaar 175-177. Hilda Verwey-Jonker, "Er moet een wrouw in. Herinneringen in een kentering won de tijd (Amsterdam 988 ), 104-129, aldaar 117-119. 126-128; EH. Reerink, "Meer research nodig." Chemisch Weekblad 63 $(1967), 1-3$. Voor de geschiedenis wan SON, zie: [FTh. Hesselink]. 'Stichting Scheikundig Onderzoek in Nederland 1956-1998"in: (NWO-Gebted Chemische Wetenschappen], Jaarboek 1999 (Den Haag 1999). 19-28.

105 G. Holst, Het apstellen wan een plan voor de Technische Hoogeschool, rede TH Delft 30 aktober 1946; Rapport betreffende een Technische Hogeschool in het industriele zuiden van Nederland (Stichting Technisch Hoger Onderwijs in het Zuiden: 2.p., 2.j. [1948]); [Commissie Holst] , Rapport van de Commissie tot Herziening wan het Technisch Hoger Onderwijs (Delft 1948); Rapport wan de Tweede Commissle Holst (Delft 1950).

106 Wim Hutter, "Chemie, chemic en wetensichapsbeleld; in: Homburg en Palm (red), De geschiedenis wan de scheikunde in Nederland. Deel 3 (te verschijnen). Zle voorts: [Commissie ontwikkeling natuurwetenschappelijk onderwijs], Voorzieningen ten behoewe wan research binnen de faculteiten der wis. en natuurkunde der Nederlandse universiteiten ("S-Gravenhage 1958); "De ontwikkeling wan het natuurwetenschappelijk onderzoek, Chemisch Weekblad 56 (1960) $33-35$.

107 J.H. van Santen, 'De wisselwerking tursien chemie, fysica en elektrotechniek bij het onderzoek wan de vaste stof", Chemisch Weekblad 55 (1959). 273-276: Schotman, "Nederland als katalysator; Joan van der Waals en Kees Hilbers, *Moleculen doorgrond: kwantumchemie en spectroscopie', in: Homburg en Palm (red.), De geschiedenis wan de scheikunde in Nederland. Deel 3 (te ver. sthijnen)

108 Eimlet van Kreveld, Jacob de Swan Arons, Peter vain de Loo en Jaap Naber. 'Shell: research en besluatworming', Wetenschap \& Samenlewing 74/4 (aprill 1974), 8-44 "Structuur DSM wordt atgestemd op marktgerichte stijl van werkeri, DSM Nieuws 20 (13) (7 juni 1971), 1-5i Te Roller, Een halve eeww Centraal Laboratorium, 20 21, H. Lintsen, J. Schueler en F. Veraart, Naar een herorièntatie van de research, $1970-1985^{\circ}$. in: Lintsen (red.), Research tussen vetkool en zoetstof, 82-103: De Vries, 80 Vears of Research, 194-197, 218; [Van Goozen] Van plattelandsapothee tot Europees bedrif, 39-40; Tausk, Organon, 398, 401-402: Verhoog. 75 jaar Organon, 84: 5 prengeri". 'Ten behoeve van de gezondheid war mens, dier en plant', 85-87, 90-93,102-103,121. 
nog speurwerk sleutel woor de toekomst. Preadviezen wht te brengen op het speuwerkcongres te Utrecht 4 maart 1965 (Haarlem 1965): "Speurwerk. sleutel voor de toekomst, Chemisch Weekblad 61 (1965). 143-144. Vgl. DW. wan Krevelen, 'De betekenis wan research voor de industriele onderneming'. Economisch Kwartadoverzicht wan de Amsterdam-Rotterdam Bank NV, ni. 47 (maart 1965), 15,-21 (ook gepubliceend in Intermediair, in De spindop 23 (1967). n. 26, en in: DW. van Krevelen. In retrospect. Een keuze wit de voordrachten (Amsterdam 1980), 101-11\%, 283), DW van Krevelen, "De ontwikkeling van de procesindustrie. Aspecten van research en ontwikkeling', Chemisch Weekblad $(1968)(24), 1+25$

no Zle bijw John R. Anchor, Managerial perceptions of research and development in the UK chemical industry, Chemistry and industry 1985, 426-430, 459-464. 498-504; Daniel V. De Simone, Technological innovation: Its Environment and Management (U.S. Department of Commerce: Washington, DC 1967); Techmological innovation in Britain. Report of the Central Advisory Council for Science and Technology (Londen 1968).

"11 Kees Blase, "Inkrimpingen treffen vooral lager personeel. Personeelsgegevens van de laboratoria van de "Grote Viff", Wetenschap \& Samenteving 82/6.7 (juni/jull 1982), 32-34. Zile ook: BLG Industriebond FNV Arla, "Van maatschappelijke relewantie tot behoud wan werkgelegenheid", wetenschop \& Samenleving 82/6.7 (juni/jull 1982), 8-12; Bedrifsledengroep Industriebond FNV, Koninklijke Shell Laboratorium Amsterdam. "Research binneri Shell, Wetenschap \& Samenleving 82/6.7 (juni/jull 1982), 13-19; Blase, "Het Nat Lab. in beweging; Klaas Schutter "Reorganisaties binnen het Uniliever laboratorium;. Wetenschap \& Samenieving 82/6.7 (juni/juli 1982), 25-27.

112 D.S. Dawies, 'De toekomst wan de research in de chemische industrie," Chemisch Weekblad (25 juni 1971), 9-14; Lucas Reijnders, Wetenschapsbeleid in Nederland (Baarn 1972), 32-48.

113. C.J. Böttcher, National en internationad wetenschapsbeleid (Rotterdam 1973). 15 (ook verschenen in: Niewwe verhandelingen wan het Batagfsch Genoatschap der Proefondervindelijke Wijsbegeente te Rotterdam, derde reeks, deel $2(6))$.

144 [C.J.F. Böttcher], 'Meer gelid nodig voor industriele research", Chemisch Weekblad (28 mrt. 1969), 13-15.

115. Archief Akzo-Nobel: notulen der wergaderingen wan de Raad van Bestuur wan de N.V. Research, 5 april 1956 en 17 juli 1956; Central Archief DSM: personeelsdossier F.L. Sixma brief 22 Februari 1963 , met bilage "Commissies professor Sixma". Begin 1963 waren lid: Troost van TWO (voorzlttery, Slotboom wan Shell, verwey wan Philips, Bredée en levison van A.KU, Van der Steur en Boekenoogen van Unilever, Sixria wan Staatsmijnen eri Berkhoff (exStaatsminen) van de TH Twente. WgI. ook'Organisatie van speurwerk', Nicume Rotterdamse Coutant, 3 december 1953.

116 Claude Oger (red.). Monte Carlo 1965, General Report (Paris 1967), en wele wol. gende ERMA-rapporten.

$117 \mathrm{Vgll}$. Hounshell, "The Evolution of Industrial Research", 50-51. 57. David Edgerton, The linear model did not exist reflections on the history and histo- 
liography of research in industry in the twenteth century, in: K. Grandin (ed). science and ind stry in the Twentieth Century. (New York, te verschijnen).

H.B.C. Casimir, 'Gental address by the chaiman of the confifence, in: [EIRMA]. Monte Carlo 1965. Principal Canference Speecher. European. North American Conference on Resiearch Maragement (Paris 1967). 9-15; C. wan Heerden, "Heeft de wetenschap grenzen?", in: Sarlemijn, Tussien academie en industrie, 147152; H.G. Casimir, 'Weterischapsontwikkeling een spanningsveld tussen wens en werkelikheid" in Sartemijn, Twssen academie en Industrie, $181-189$, aldaar 185-186; De Vies, 80 Vears of Research, 106-107 Vgl. Relinders, Wetenschapsbeleid, 33-34. Woor de "zuigkracht" van de biochemile, zle: Ton van Hevoort, Biochemie tusen nut en cultur. De 'triple helix' van de Nederlandse biowetenschappen (z.p. 2002).

Chalmers W: Sherwin en Raymond S. isenson, 'Project Hindsight: A. Defense Department study of the utility of research", Science 156 (1967), 1571-1577;

[Loelbach (red)]. Technology in Retrospect, 2 delen (1968-1969); Karl Kreilkamp "Hindsight and the real world of science pollcy", science Studies 1 (1971), 43-66; David C. Mowery en Nathan Rosenberg. 'The influence of market demand upon innovation: a critical review of some recent empirical studies". Research Policy 8 (1979), "103-153, ook gepubliceerd in Nathan Rosienberg, Inside the Black BOX Technolagy and Economics (Cambridge 1982), 193-241.

Over de invoering van matrix-organisaties, zie. C.H. Buitenhuls, Organisatie van innovatie. Innovatle von arganisatie. De matrix als stimulans voor wernieuwing, proefschrift TH Eindhoven, 44 januari 1977 (case studies bij Philips); De Laat Een kwestie van vertrouwen.

Vera llles en Kees Caljé, Coede raad is duur. Organisatie adviseurs in Nederland (Amsterdam 1986); Max Christern en Max Houben, ${ }^{\circ}$ De klanten van McKinsey zijn steeds slimmer', NRC Handelsblad, 4/5 oktober 2003; 14. Vgl. ook themalnummer over "Research management" Chemisch weekblad (19 mrt. 1971); Anchor, "Managerial perceptions of research and development", $429 \cdot 430,460$ 461.

H. Kramers; "Filosofie van research management in een grote onderneming", Chemisch Weekblad (19 mrt. 1971), R6-R9; WJ. Beek, "Industrieel onderzoek", Chemisch Weekblad (25 mei 1973), 20-22 en (1juni 1973), 14-16; Centraal Archief DSM:Concernarchief - stukken betreffende research, 1976-1984: A.H. de Rooilj, Discussienota. De exploratieve research bij DSM: samenvatting van de ontwikkelingen in de periode 1975/77 en richtlinnen woor de toekomst, Celieen 4. oktober 1977: "Extra inspanning voor exploratteve research ter bevordering van industriêle innovatie", DSM Magazihe (febr. 1979), 6-7. Wat betreft de aandacht voor "innovatie, zile bijwoorbeeld: De Simone, Techrological Innovation (1967): Techmological Mnavation in Britain (1968), Buitenhuis, Organisatie van innovatie (1977): [A.A.Th.M. van Trier], Innovatie. Het overheidsbeleld inzake technologische vernieuwing in de Nederlandse somenlewing. Tweede Kamer der Staten Generaal Zitting $1979-1980$, nir. 15855 (' S Gravenhage 1979).

Peter Groenewegen, "Reorganisatie en automatisering. Wetenschop \& Samenleving $82 / 6.7$ (jumiduli 19.8.2) $49-53$.

Schutter, "Reorganisaties"; Loe C. ten Cate. De sluiting van het Unlever 
Research Laboratorium Duiven. Oorzaken en strategieem, onderzoeksversigg bijwak Wetenschap \& Samenleving, RU Groningen, augustus 1980

$126 \mathrm{HJ}$ Vink ${ }^{*}$ Het wetenschapsbeleid wan een grote onderneming; Wetenschap \& Samenlewing 5 (7) (sept. 1973), 74-179; De Vries, 8 o vears of Research, 200-242: Boersma en De Viles, De veranderende rol van het Natuurkundig Laboratorium: $306-310$.

127 woor een beschowwing over de Amerikananse ontwikkelng gedurende het Reagan tijperk, zle Hounshell, "The Evolution of industrial Research', 51-56. Mowery en Rosenberg, Paths of Innowation, 45-46. Voor de ontwikkelingen bij Phillips tussen 1972 en 1994. zie: De Vies, 80 Vears of Research. $199-278$. Boersma en De Vries, De veranderende rol van het Natuurkundig Laboratorium', 306-310; Jan Jacobs, 'Plet, waar zijn die gekken toch geblewen? De nieuwe non-contormisten wan Philips' Natlab" De Volkskrant (2i aptil 1984): A.E. Pannenborg, 'Bedrijfskunde van laboratoria een academisch vak", Chemisch Weekblad (6 dec. 1984), 387; A.E. Pannenborg e.a. Spanningswelden tijdens technologische ontwikkelingem. Over relaties wissen research bedriffs. filosofe, markt en somenleving (Eindhoven 1986).

128 Anchor, "Managerial perceptions of research and development", 500-503; [Unilever], Charts $7982-1992$ (z.p., z.j.). 8; I. Nieuwenhuis, 'Lange-termijnonderzoek motor achter toekomstige produkten;, Chemisch Weekblad (19 nov. 1992), 384: [Unilever Research Laboratorium Waardingen], Science for Worldwide innovations (Vlazdingen 1996).

129 "Nat Lab. 75". Chemisch Magazine (mei 1989), 315-321, 324; Dick van Eijk, Op de werkwloer van het Natlab; NRC Handelsblad (27 febr. 1990). Bart Verspagen. "Large firms and knowledge flows in the Dutch R\&D system. A case study of Philips Electronicsi, interne paper TUE/ MERIT, UM, 1998, H.Lintsen en F. Veraart, "De nieuwe bloel van de research, 1985-1990, in: Lintsen (red), Research tussen wetkool en zaetstof, 104-115; E. Homburg, "Eploog: DSM Research op weg naar de 21 ste ee ww', in: Lintsen (red.), Research tusseri vetkool en zoetstof, 116-135: Alexander Duyndam en Fridus Valkema,"Het idee dat je memo gelezen wordt. Emmo Meijer: DSM gaat research inspanning fllink opwoeren; ChemischeaWeekblad (16 mrt. 2002), 10-11; WNCl Jaarverslag 1995 (leidschendarn 1996), 42 (vgl. Chemisch Magazine, Juni 1996, 237); Henk Tolsma, "Bedrijfs-R\&D gaat gelijk op met de groei van de aconomie', Technisch Weekblad (2 aug 2000), "1, Bert Minne en Marieke Rensman, 'De R\&D-strategie van de Nederiandse chemische industrie, chemischaweekblad $97(2)$ (") febr. 2001), 12-14: Bert Minne en Marieke Rensman. Ki D-strategie wan de Nederlandse chemische industrie. Trends in de afgelopen dien jaar (Den Halag 2001) (= CPB Memorandum IV/2001/3); Maarten Coninet en Marieke Rensman, The Location of R\&D in the Netherlands: Trends, Determinants and Policy (= CPB document no. 14) (Den Haag 2001), mn. 20-24: Herman Noordman, leanette Verbruggen en Bert Minne, Half a Century of Dutch Manufacturing. Annual Reports $1950-2000$ (= CPB document no 37) (Den Haag 2003), 30. Voor recente ciffers, zie: www cpbnt/nl/general/org/afdelingeritiviesearch.

30 Voorbeelden zijn de voormalige chemie-giganten Hoechst. $I C l$ en Clba-Geigy. 
Ook het Duitse Bayer zal worden opgesplitst. Akzo brach har wezelactiviteiten onder in de niteuwe onderneming Acordis. Wgl. Fred Aftalion, A History of the International Chemical industry. From the "Early Days" to 2000, 2e druk (Phladelphia. 2007), 374-405; Minne en Rensman, R\&D-strotegie wan de Nederlandse chemische industrie, $4-5$.

131 Ondanks deze groelende samenwerking zijn de contacten tussen universiteit en bedriffieven slechts goed woor ongeveer 20 procent van alle samenwerkingsverbanden op kennisgebied van Wederlandse ondernemingen. Samenwerking war bedrijwen met leveranciers en afnemers heeft een veel groter aandeel. Zie: Marlus T.H. Meeuws, Innoveren en organiserem. Over het werklaren wan (on-jwerenigbare grootheden, inaugurele rede Universitelt: Utrecht, 9 mel $2003,7-8,12-13$.

132 Henk Bodewitz, "De opkomst van het akademisch-industrieel kompleks", Wetenschap \& Samenlewing $1983 / 2$ (feor 1983). 33-39: Henk Bodewitz; De veranderende relatie tussem universtair en ndustrieel onderzoek. De situatie in de VS en haar invloed op Nederland', Wetenschap \& Samentewing $85 / 9$ (nov. 1985). 4.72; E de Boer (red.), Chemie in het zilver. Hoe halen we het goud? Universitaire chemie in de jaren negentig. 25 joar Sectie scheikunde, Katholieke Universiteit Nijmegen, $1962-1987$. Verslag Jubileumsymposim i oktober 1987 (Nijmegen z.j. [1988]), met o.a. bijdragen van J.L.K.F. de Vries (5hell), D.J. Venderbos (DSM), F. Mejler (Philips), I.C.P. Broekhoff (Unilever) en K. Wied haup (Organon/Akzo) ower het thema 'universiteit en industrie:. Voorts o.a.: Marcel Grok, 'Publiek debat nodig over chemiestudie," Chemisch Weekblad lig okt. 9996), 6-7; Jos de Kooyker, "Samenwerking is de kracht van Nederlands onderzoek. Prof. Geus zet contractonderzoek voort na emeritaat, Chemisch Weekblad (23 mel 1998), 3; Krijn de Jong, Universiteit moet geen bedrijfje spelen, Chemischaweekblad (8 mei 1999), 4.

133 M.A. van Damme-van Weele, "Verwachtingen varuit het bedriffstewen aangaande het overheids-onderzoekseleid" Voordracht gehouden op at augustus 1980 tjidens het Zomercongres 1980 van de Koninklike Mederlandse Chemische Vereniging (Akzo Speakers Series 80/1: Arnhem 1980); "Researchdoelen: noodzaak en ulitdaging', Chemisch Weekblad (4 dec. 1980), 526-527: Schuijer, 'Elf miljoen nodig voor polymeren', Chemisch Weekblad (24 dec. 1987), 505: 'Nederlandse R\&D kalff af", Chemisch Weekblad (22 sept. 1988), 389: [Frans van Steinn], Universitail onderzoek als mogelijke basis woor industriele R\&D; Chemisch Weekblad (25 december 1993), 6-8; Verhoog. 75 jaar Organon, 100$10 \%$

34 Het aantal contracten dat DSM afsloot met, aanvankelijk voornameljk Nederlandse, universiteiten steeg vari 85 in 1986 tot 150 in 1988189 . In 2003 onderheld DSM structurele contacten met circa 2000 universtatre wetenschappers 'world wide". Zle: D.J venderbos, "Universiteit: quo vadis?" in: De Boer (red.), Chemie in het zilver, 12-18, aldaar 16; "Venster op de buitenwereld. Afdeling "Universtaire er Wetenschappelijke Contacten (UWC) bij DSM Research", DSM Magazine (mel 1993), 28 31; Frans van Steijn. "De vierde generatie R\&D. Interview met Ludo Kleintjens', chemisch Weekblad (s maart 1994). 4: 'Research steeds internationaler. Samenwerking met Russian Institute of 
Chemical Physics in Moskou', DSM Mheuws (8 okt. 1998), 1; Ludo Kleintjens, college over industrie-universiteits relaties, voor ESST-studenten, Universiteit Maastricht, 9 oktober 2003. Zie woorts: Minne en Rensman, R\&D-strategie van de Nederlandse chemische industrie, 3,4 .

135 P. Lemstra, 'Discussion paper: Nedierland, kennis(sen)land: over samenwerking academia en industrie: Eindhowen, augustus 2002; P.J. Lemstra, 'Nederland, kennis(sen)land?', Crosslinks nr. 50 (september 2003), 4-5i. Fridus Valkema, 'Schaalvergroting in kennisland', Chemisch2Weekblad (14 aug. 1999), 3; Fridus Valkema, 'Nederland exporteert R\&D model', Chemischa Weekblad (1 dec. 2001). 3; [Dutch Polymer Institute], Strategic Research Alliance Academia - Industry (Eindhoven 2000).

136 [FTh. Hessellink], "Stichting Scheikundig Onderzoek in Nederland 1956-1998. $23-24$.

137 Vgl. ook de interviews van Frans van Steijn met resp. Jan Zuidam (DSM), Dick Medema (Shell), Hans Nieuwenhuis (Unilever) en Joop Roels (Gist): "Er gaat een grote schokgoif door r\&d', Chemisch Weekblad (23 okt. 1993). 4; "Misschien waren we aan de softe kant', Chemisch Weekblad (27 november 1993). 4:'Alles begint met een markt: Chemisch Weekblad (25 december 1993). 4: 'De snelheid van onderzoek opvoeren," Chemisch Weekblad (12 febr 1994). 4 .

138 Minne en Rensman, $R \& D$-strategie van de Nederlandse chemische industrie, 5. 8. Cornet en Rensman, The Locotion of R\&D in the Netherlands, 11-19.

139 Dirk van Delft, "Het geketende onderzoek: Academisch ingestelde onderzoekers nemen de wijk nalar de universiteit", NRC Handelsblad, bijlage Wetenschap \& Onderwijs, 31-8-1996; "Valk. Back to Casimir', Chemischaweekblad (27 mrt. 1999), 34. Zie ook: Lemstra, 'Nederland, kennis(sen)land'; Piet J. Lemstra, The rise and decline of polymer science \& technology in Europe Macromolecular sciences and polymer technology at the crossroads?', in: Polymers in Europe: Quo Vadis? (Ospedaletto-Pisa 2001). 5 -8.

140 Homburg, "Epiloog", $127-135$.

141 Fridus Valkema, 'Hoe industriële $R \& D$ beter te laten renderen?", Chemischaweekblad (13 febr. 1999), 26-27; Maarten Evenblij, "Sclinuiven met hersens en met geld", De Volkskrant 1999; Patrick Marx, "Shell laboratorium opent de poorten voor bedrijven'. Chemischa Weekblad (14 aug. 1999), 6; fridus Valkema, 'Creativiteit leidt tot nieuwe loopbanen', Chemischa Weekblad (16 jan. 2000). 26; 'Valk', Chemischaweekblad (11 mit. 2000), 50; 'Valk'. Chemischaweekblad (20 mei 2000), 54: Mirne en Rensman, R\&D-strategie van de Nederlandse chemische industrie, 3-4, 11-12. Over het KSLA, zle ook de sleutelroman: Jan Wortel, Een ster als alibi (Alphen aan de Rijn 199g).

14.2 Research within Akzo 1986 (Arnhem 1986): Research within Akzo 1990 (Arnhem 1990); Peter de Haan, 'Fact and figures', Akzo Nobel News \& Views. Special: Technology (Febr. 1997), 2; "Valk" Chemischa Weekblad (13 mrt 1999), 38; Doetze sikkema, 'Industrie verwaarloost langetermijnonderzoek'. Chemisch 2Weekblad (23 sept. 2000), 12-13; Fridlus Valkema, "Industriële R\&D kan niet zonder de R', ChemischaWeekblad (18 nov. 2000), 3: Dirk van Defft, "Techneuten krijg je er niet onder". Noor van Andel over Akzo Mobel en de macht van de aandeel houders', NRC Handelsblad, zaterdag 6 januari 2001,43: 
"Noor van Andel krijgt eredoctorat van UwA, Chemischaweekblod (27 Jan 2001), 7" Vak", Chemischaweekblad (10 febr 2001), 34. Vgl ook Verhoog, 75 joar Organon, 100-102: Lemstra, "Nederland, kennis(sen)land".

143 Fridus Valkema, 'Industrie mort over de uniwersiteit', ChemischaWeekblad 122 mei 1999) 8; ian de Wit, "Schaf derde geldstroom af. Nieuw model nodig voon samenwerking universiteit-industre', Chemischaweeklad (13 jan. 200n), 8; Fridus valkema, Industrle moet leren vissen in de vijvers van de universiteit. Intervew met Prof Jan de Wit (Akzo Nobel) ChemischzWeekblad (27 jan. 2001). 4-5; kees Elsevier, "Roofvissen in universitalie wijver" Chemischz Weekblad (24 febr. 2001 ), 4 -5. Fridus Valkema, "Discussie tussen industrie en universiteit nodig., Chemischaweekblad (10 mirt: 2001), 3; Stephen Picken. "Industrie ontbeert lange termijn wisie" Chemisch2 weekblad (24 mrt. 2001), 3 ; Fridus Valkema, Als je wilt vissen moet je weten hoe je herigettje gebogen is. Interview met ACC-voonzitter Prof. Gerard van Koten, ChemischaWeekblad (24 mrt. 2001), 12-13; "rmmo Meljer, "Persoonlijk gastcollege "wiste", Chemischa Weekblad (21 apr. 2001), 4; Kees linse, "De unwersiteit weet niet alles beter". ChemischaWeekblad (21 apr. 2001), 5; Smith, "Industrie gedwongen tot LATrelatie; Sarah wan LeeUwen, "VNCI will $50 \%$ meer geld voor chemische R\&D" ChemischaWeekblad (ng mel 2001), 9; Bart Drinkenburg "Zorg woor complementariteit", ChemischzWeekblad (2 juini 2001), 4; Fridus Valkema; "Bescherm universtaire kennis", Chemischa Weekblad (16 febr. 2002). 3 .

144. Lemstra, 'Discussion paper", 1,4 .

145 Minne en Rensman, R\&D-strateghe wan de Nederlandse chemische industrie. 1-3i Rein de Wilde, De voorspellers. Fen kritiek op de toekomstindustrie (Amsterdam 2000). 